Kelly Dhayane Abrantes Lima

\title{
Modulação da interação neutrófilo-endotélio in vitro por melatonina: ação sobre as células endoteliais
}


Kelly Dhayane Abrantes Lima

\section{Modulação da interação neutrófilo-endotélio in vitro por melatonina: ação sobre as células endoteliais}

Dissertação apresentada ao Instituto de Biociências da Universidade de São Paulo, para a obtenção de Título de Mestre em Ciências, na Área de Fisiologia Geral.

Orientadora: Regina Pekelmann Markus

São Paulo 


\section{Ficha Catalográfica}

Lima, Kelly Dhayane Abrantes

Modulação da interação neutrófiloendotélio in vitro por melatonima : ação sobre as células endoteliais / Kelly Dhayane Abrantes Lima ; orientadora Regina Pekelmann Markus. --. São Paulo, 2011.

$85 \mathrm{f}$.

Dissertação (Mestrado) - Instituto de Biociências da Universidade de São Paulo. Departamento de Fisiologia

1. Processo inflamatório. 2. Melatonina. 3. Células endoteliais. 4. Moléculas de adesão. I. Universidade de São Paulo. Instituto de Biociências. Departamento de Fisiologia. II. Título.

\section{Comissão Julgadora:}

Prof(a). Dr(a).

Prof(a). Dr(a).

Prof(a). Dr.(a). Regina Pekelmann Markus

Orientador(a) 


\section{Dedicatória}

Dedico à minha família

e a todos que comigo lutaram

para mais uma vitória. 


\section{Epígrafe}

"Não há ensino sem pesquisa e pesquisa sem ensino. Esses quefazeres que se encontram um no corpo do outro. Enquanto ensino continuo buscando, reprocurando. Ensino porque busco, porque indaguei, porque indago e me indago. Pesquiso para constatar, constatando intervenho, intervindo educo e me educo. Pesquiso para conhecer o que ainda não conheço e comunicar ou anunciar a verdade"

Paulo Freire (1921-1997)

"O que prevemos raramente ocorre; o que menos esperamos geralmente acontece."

Benjamin Disraeli

(1804-1881) 


\section{Agradecimentos}

A eles, que não mediram esforços para a realização deste sonho: minha mãe Vera que com força e coragem me ensinou a lutar com muita garra e meu pai José Maria que me ensinou com sua simplicidade o verdadeiro sentido da vida.

À minha orientadora Regina Pekelmann Markus, pela confiança depositada, calma, conselhos, pela oportunidade, pela compreensão, por todo o ensinamento transmitido. Obrigada por todo incentivo!

Aos que comigo riram, choraram, mas tiveram sempre uma palavra de estímulo durante as jornadas de trabalho no laboratório: Os "mineirinhos de mi vida" Cláudia, Marina, Sanseray e Marco. "Nóis de Minas invadimos o laboratório uai!" Camila pela amizade que espero levar para o resto da vida, Daiane (adoro essa menina), Erika (pequena grande mulher, nunca esquecerei o que fez por mim), professor Pedro (o professor mais bobo que eu já conheci), Luciana (mineira em potencial), Zulma (sempre ajuda nos piores momentos, pois nos melhores ela sabe que damos conta) e em especial ao meu co-orientador Eduardo Koji Tamura (o japonês mais brasileiro que já conheci, ou será o contrário?) por ter acreditado em mim, pela paciência, e por todo o ensinamento. Aos que passaram pelo laboratório e deixaram suas marcas: Alex, Ariana, Cecília, Cris, Janaína. A Débora pelo apoio técnico e pela amizade. E aos novos integrantes dessa equipe: Danilo, Gabriela, Leila, Eduardo e Luis.

Aos amigos que fiz durante este trajeto: professora Ana Castrucci, Leonardo, professora Maristela, Luciana, Tiago, Márcio. Obrigada por tudo!

À grande amiga de ontem hoje e sempre Maria Nathália pela companhia, conselhos, preocupação e, principalmente, por ter feito minha primeira festa surpresa!

Aos tios Nilson e Maria Ducarmo, e aos primos Ligiane e Jefferson pela amizade.

À vovó Elza pelas orações e amor incondicional.

As amigas Ani e Beatriz, por me acolherem em sua família e me apoiarem quando eu mais precisei.

Aos tios Nilton e Gisele pelas horas de boas conversas. 
Ao Colégio Cenecista de Caratinga e todos os professores pelos ensinamentos e participação na formação da minha personalidade.

À tia Inêz que mesmo longe me ajudou sempre que precisei, ao Cláudio pelos conselhos e aos primos Ana Claudia e Matheus, pelo apoio.

Aos meus irmãos Chraisller e Clayton por fazerem parte da minha vida. E aos irmãos que ganhei Gisele e Kennedy por surgirem em minha vida.

Ao Tammam que foi muito mais que companheiro nesta caminhada.

Ao Centro de Ensino Superior de Juiz de Fora (CES/JF) e a todos os professores que contribuírem para minha formação.

Ao Departamento de Fisiologia do Instituto de Biociências da Universidade de São Paulo e a todos os seus integrantes e professores que participaram do meu crescimento pessoal e principalmente professional.

À CAPES, CNPq e FAPESP pelo apoio financeiro. 


\section{Lista de Abreviaturas}

$\mu \mathrm{L}$

5-HT

5-HTP

5-MCA-NAT

AA-NAT

AMPc

C5a

CD11/CD18

CEUA

COX

DAPI

EDTA

eNOS

EPM

FAP

FITC

GCS

HIOMT

$\mathrm{hMT}_{1}$

$\mathrm{hMT}_{2}$

ICAM-1

IKB

IL-1 $\beta$

IL-2

IL-6

IL-8

IL-12

INF $\gamma$

iNOS

IUPHAR

microlitro

5-hidroxi-triptamina/ serotonina

5-hidroxi-triptofano

5-metoxicarbonilamino- $\mathrm{N}$-acetil-triptamina

enzima arilalquilamina- $\mathrm{N}$-acetiltransferase

adenosina monofosfato cíclico

componentes do sistema complemento

moléculas de adesão da família das $\beta 2$-integrinas

Comissão de Ética no Uso de Animais

ciclooxigenase

4,6-diamidino 2-fenilindol, diidrocloreto

ácido etilenodiaminotetraacético

sintase de óxido nítrico endotelial

erro padrão da média

fator de ativação plaquetária

isotiocianato de fluoresceína

gânglio cervical superior

hidroxi-indol-O-metiltransferase

receptor humano de melatonina do subtipo 1

receptor humano de melatonina do subtipo 2

molécula de adesão intracelular tipo 1

proteína inibitória kappa B

interleucina- 1 betta

interleucina-2

interleucina-6

interleucina- 8

interleucina-12

Interferon gamma

sintase de óxido nítrico induzida

União Internacional de Farmacologia 
LPS lipopolissacarídeo

M

molar

MEL

melatonina

$\mathrm{mM}$

milimolar

$\mathrm{MT}_{1}$

receptor de melatonina do subtipo 1

$\mathrm{MT}_{2}$

receptor de melatonina do subtipo 2

$M T_{3}$

receptor de melatonina do subtipo 3

MTT

(3-(3-4,5-dimetiltiazol-2yl)-2,5-difenil brometo de tetrazolina)

NA

noradrenalina

NAS

$\mathrm{N}$-acetilserotonina

NFKB

Fator de transcrição nuclear kappa B

NLS

sítio de sinalização

$\mathrm{nM}$

nanomolar

NO

óxido nítrico

NPV

núcleo paraventricular

NSQ

núcleos supraquiasmáticos

PBS

Tampão fosfato

PCL

fosfolipase C

PE

ficoeritrina

PECAM-1

moléculas de adesão de células endoteliais e plaquetas tipo 1

PKC- $\alpha$

proteína cinase $\mathrm{C}$ alfa

$\mathrm{pM}$

picomolar

PMN

polimorfonucleares

QR2

quinona redutase 2

ROR

receptor órfão para ácido retinóide

RZR

receptor $\mathrm{Z}$ para ácido retinóide

TAD

domínio transativador

TGF- $\beta$

fator de crescimento e transformação-beta

TLR4

receptor de membrana (toll-like receptor 4 )

TMB

tetrametilbenzidina

TNF

fator de necrose tumoral

VCAM-1

moléculas de adesão de células vasculares 


\section{ÍNDICE}

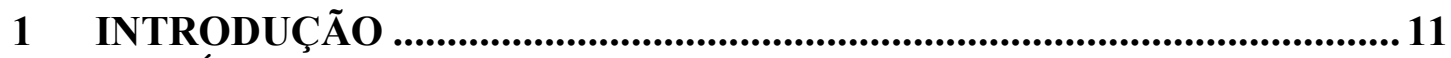

1.1 CÉLULAS ENDOTELIAIS VASCULARES .......................................... 11

1.2 PROCESSO INFLAMATÓRIO …………………................................ 12

1.2.1 Eventos vasculares e mediadores da inflamação aguda ....................... 13

1.2.2 Eventos celulares e moléculas de adesão ............................................ 14

1.2.3 Fator de transcrição NFKB ................................................................ 17

1.3 LIPOPOLISSACARÍDEO (LPS) COMO INDUTOR DA INFLAMAÇÃO

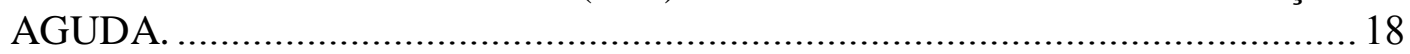

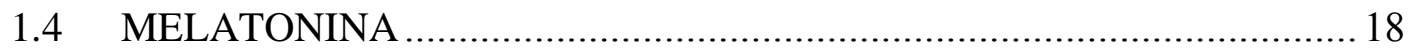

1.4.1 Produção e regulação da liberação de melatonina ............................... 19

1.4.2 Biossíntese da melatonina .................................................................. 21

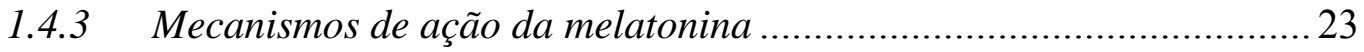

1.4.4 Receptores de melatonina ....................................................................2 24

1.4.5 Ações intracelulares da melatonina .....................................................2

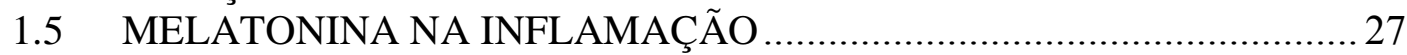

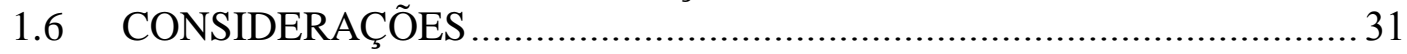

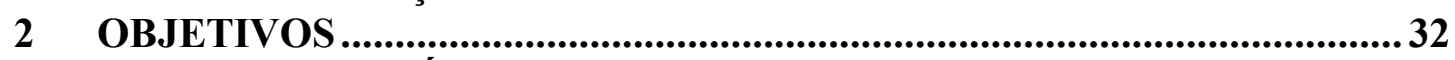

3 MATERIAL E MÉTODOS.................................................................33

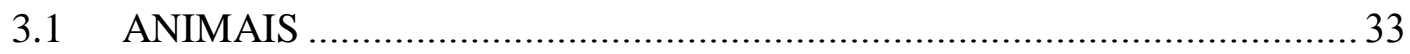

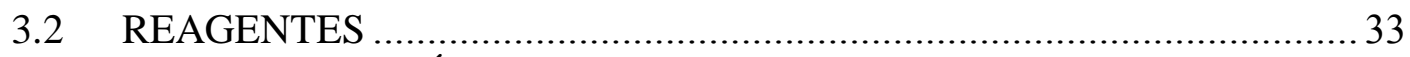

3.3 CULTURA DE CÉLULAS ENDOTELIAIS …………………………......... 34

3.4 ENSAIO DE EXCLUSÃO POR AZUL DE TRIPAN …………………..... 35

3.5 ENSAIO DE ATIVIDADE METABÓLICA (MTT) ....................................37

3.6 OBTENÇÃO DOS NEUTRÓFILOS ...................................................... 37

3.7 ENSAIO DE ADESÃO NEUTRÓFILO-ENDOTÉLIO IN VITRO .............38

3.8 IMUNOCITOQUÍMICA PARA MOLÉCULAS DE ADESÃO (PECAM-1) 39

3.9 IMUNOCITOQUÍMICA PARA MOLÉCULAS DE ADESÃO (ICAM-1) 40

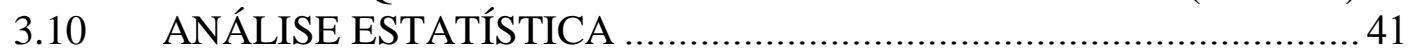

4 RESULTADOS .................................................................................................42

4.1 EFEITO DA MELATONINA NA PROLIFERAÇÃO DE CÉLULAS

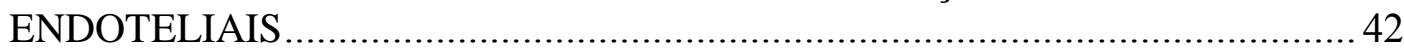

4.2 PADRONIZAÇÃO DO ENSAIO DE ADESÃO NEUTRÓFILO-

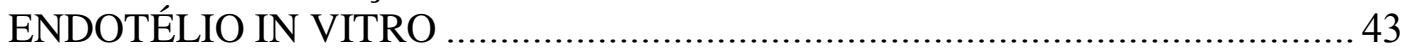

4.2.1 Determinação da concentração de células endoteliais.......................... 43

4.2.2 Determinação da concentração de neutrófilos...................................... 44

4.2.3 Efeito do LPS na adesão de neutrófilos ............................................. 45

4.2.4 Efeito do LPS na expressão de PECAM-1 ……….......................... 46

4.2.5 Efeito do LPS na expressão de ICAM-1 ……................................... 48

4.3 EFEITOS DA MELATONINA …………………................................4 49

4.3.1 Adesão de neutrófilos ...................................................................... 49

4.3.2 Expressão de moléculas de adesão PECAM-1 e ICAM-1......................51

5 DISCUSSÃO ................................................................................................56

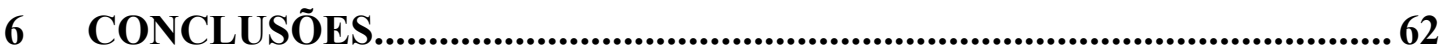

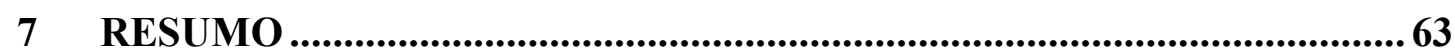

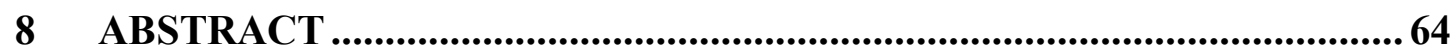

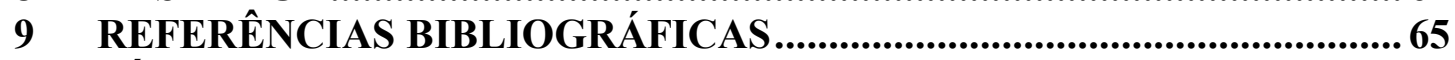

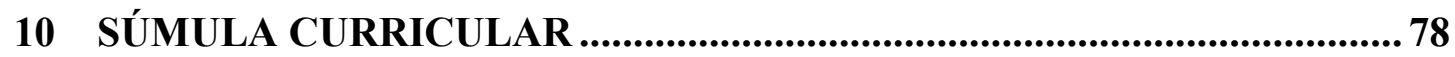




\section{INTRODUÇÃO}

\subsection{CÉLULAS ENDOTELIAIS VASCULARES}

As células endoteliais revestem o interior dos vasos sanguíneos. São responsáveis pela regulação da homeostase vascular estando em contato direto com o sangue e com as células musculares lisas. São sensíveis às mudanças na composição e no fluxo sanguíneo. Participam de processos fisiológicos e fisiopatológicos e têm a capacidade de produzir e responder a diferentes moléculas sinalizadoras (Cook-Mills e Deem, 2005).

O estudo da função endotelial vem sendo feito tanto em preparações isoladas de órgãos, como em culturas de células. No caso de preparações isoladas de órgãos, podem-se mencionar os estudos clássicos e pioneiros de Furchgott, que deram a este pesquisador o Prêmio Nobel de Medicina de 1998. Naqueles experimentos foi verificado que a retirada do endotélio de uma preparação de aorta isolada impedia o efeito relaxante da acetilcolina (Carneiro et al., 1991; Furchgott, 1998). Trabalhos posteriores esclareceram que a acetilcolina atua diretamente sobre receptores muscarínicos localizados nas células endoteliais promovendo o aumento de cálcio intracelular e a ativação da sintase de óxido nítrico endotelial (eNOS). Estes trabalhos pioneiros mostraram que estas células eram essenciais para o controle do tônus vascular (Busse et al., 1985) e, portanto, da pressão arterial. Trabalhos subsequentes demonstraram que esta monocamada celular é também responsável pela migração de células sanguíneas para o tecido e pela própria angiogênese (para revisão, Fajardo, 1989).

O estudo da função endotelial envolve diferentes técnicas buscando o entendimento de suas reações. Para tanto tem sido utilizada a técnica de cultura in vitro das mesmas.

Os estudos com células em cultura permitem avaliar diretamente a participação destas em fenômenos fisiopatológicos. No entanto, a retirada das células do tecido pode criar situações artificiais, fazendo com que seus resultados sejam 
sempre cotejados com os obtidos com os tecidos intactos. A cultura primária é preparada de tecidos retirados de um organismo, evitando alterações que possam ocorrer ao se multiplicar as células in vitro. Para a obtenção destas células, muitos autores usam enzimas capazes de digerir proteínas responsáveis pela interação célulacélula (Ryan et al., 1982). Outra forma de obter células endoteliais em cultura é permitir que estas migrem do tecido para o substrato de cultura de forma espontânea (Chen et al., 1995). Neste caso, não há perda de várias proteínas de membrana, pois não são utilizadas enzimas proteolíticas.

Em vista do exposto, para o entendimento da relevância das células endoteliais em um processo, é interessante que estas sejam analisadas de forma independente, em cultura, mas resguardando as proteínas que são expressas na face extracelular da membrana plasmática, visto que muitas destas são receptores para agentes exógenos.

\subsection{PROCESSO INFLAMATÓRIO}

Os seres vivos estão constantemente expostos à entrada de patógenos através da pele, das mucosas, e de outros órgãos e tecidos, os quais podem comprometer as funções do organismo, ou até mesmo causar sua morte (Voltarelli, 1994). Estes possuem mecanismos de defesa em resposta a estímulos agressivos, que podem ser físicos, químicos ou biológicos.

O processo inflamatório tem como objetivo a destruição, isolamento ou diluição do agente agressor por intermédio de reações teciduais, principalmente vasculares, podendo ser então considerado uma reação de defesa local. Neste contexto, as células endoteliais são de extrema importância, pois fazem a interface entre o sangue e o tecido, contribuindo para a detecção dos organismos invasores.

A resposta inflamatória evolui no tempo, permitindo caracterizar fases definidas que em alguns momentos são concomitantes (Robbins et al., 1986). A primeira é chamada de fase pró-inflamatória, iniciada pela detecção de padrões moleculares associados a patógenos, vasodilatação local, rolamento, adesão e transmigração de leucócitos. Estes fenômenos vêm acompanhados de aumento da permeabilidade vascular havendo, portanto, extravasamento de líquido. Do ponto de 
vista físico nota-se vermelhidão, formação de pápula e na dependência dos mediadores liberados, pode haver prurido. Concomitantemente, mas um pouco defasada no tempo inicia-se a fase antiinflammatória, através da produção de glicocorticóides devido à ativação do eixo hipotálamo-hipófise-adrenal, e da produção de citocinas antiinflamatórias. Esta fase tem duração mais longa e tem como objetivo a resolução do problema. Este processo de defesa é chamado de resposta inflamatória aguda, ou resposta imune-inata. O resultado final do processo inflamatório agudo pode ser a cura ou, se o agente agressor persistir, pode se transformar em inflamação crônica (Rang et al., 2001).

Existem ocasiões em que o processo inflamatório pode interferir seriamente na função do órgão atacado, podendo levá-lo a uma condição mais prejudicial que a inicial, ocorrendo perda do controle da resposta. Assim, a inflamação assume um papel destrutivo, prejudicial ao organismo. Outras vezes, os mecanismos que distinguem as células autógenas das células invasoras falham, e o sistema imunológico ataca as próprias células do organismo. Como resultado desses processos pode ocorrer doenças como, diabetes mellitus, esclerose múltipla, cirrose hepática e artrites reumatóides. Nesta situação, a inflamação não é mais considerada uma reação de defesa local, mas sim uma reação de resposta maléfica ao organismo acometido. A intensidade da resposta inflamatória e o tempo de duração determinam diferentes graus ou fases de reação nos tecidos, caracterizando uma inflamação como aguda ou crônica (Rang et al., 2001).

\subsubsection{Eventos vasculares e mediadores da inflamação aguda}

O processo inflamatório agudo induz alterações metabólicas em vários órgãos e sistemas. Estas alterações são mediadas pela liberação de substâncias químicas, causando uma cascata complexa de eventos bioquímicos e celulares. Dentre estes estão: a vasodilatação produzida por mediadores como histamina e prostaglandinas, formados através da interação do patógeno com o tecido; o aumento da permeabilidade vascular mediado, além da histamina, pelo fator de ativação plaquetária (FAP); recrutamento e migração de leucócitos para o tecido, mediados, 
entre outros, por componentes do sistema complemento C5a que é fortemente quimiotáxico; e o aumento do metabolismo celular. Cada uma dessas alterações está relacionada a um ou mais tipos de manifestações clínicas. A dor é causada pela liberação dos mediadores solúveis, pelo extravasamento de fluidos e pelo influxo celular. O calor é determinado pelo aumento do metabolismo celular, pelo aumento do fluxo sanguíneo e pela vasodilatação. O rubor é ocasionado pelos mesmos eventos do calor. O tumor se forma através da vasodilatação, do extravasamento de fluidos e do influxo celular. Esses sintomas se expressam em parte ou em sua totalidade dependendo do local onde ocorre o processo inflamatório, podendo acontecer interferência ou alteração na função do tecido, como a limitação de movimentos quando a inflamação afeta as articulações (Robbins et al., 1986; Rang et al., 2001).

Independentemente da natureza do estímulo desencadeante, as células ativadas do sistema fagocítico mononuclear (monócitos circulantes e macrófagos teciduais) iniciam a cascata de eventos da reação da fase aguda secretando, em uma etapa inicial, citocinas pró-inflamatórias da família da interleucina-1 beta, interleucina-6 (IL-6) e o fator de necrose tumoral (TNF), as quais podem agir isoladamente ou em combinação com hormônios (Baumann et al., 1990). Localmente, essas moléculas agem sobre células da matriz ou estroma tecidual, principalmente fibroblastos e células endoteliais, causando a liberação de um segundo conjunto de citocinas que incluem IL-6, interleucina-8 (IL-8), proteínas inflamatórias e quimiotáxicas de macrófagos. As proteínas quimiotáxicas, em conjunto com a interleucina-1, IL-8 e o fator de crescimento e transformação-beta (TGF- $\beta$ ), atraem para o foco inflamatório monócitos e neutrófilos, os quais secretam um terceiro conjunto de citocinas que retroalimentam o processo inflamatório (Baumann e Gauldie, 1994).

\subsubsection{Eventos celulares e moléculas de adesão}

Macrófagos e células dendríticas residentes, quando ativados liberam fatores que induzem a migração de leucócitos para os tecidos afetados. A migração leucocitária é feita através da transmigração endotelial por um processo conhecido 
como diapedese (Nourshargh et al., 2006). A adesão dos leucócitos às células endoteliais e sua posterior migração de acordo com Alexander e Granger (2000) é mediada por moléculas de adesão especializadas que são expressas tanto nas células endoteliais quanto nos leucócitos.

Os neutrófilos são os primeiros a chegar ao tecido inflamado, visto que migram através do endotélio de forma ativa (Cook-Mills e Deem, 2005, figura 1). Os neutrófilos normalmente circulam pelo centro da corrente sanguínea. Moléculas que sinalizam a montagem de uma resposta inflamatória aguda induzem a marginalização dos neutrófilos que rolam sobre a camada endotelial. A seguir pode ocorrer a adesão e transmigração destas células. Neste processo de diapedese os neutrófilos são ativados e ocorre a indução da transcrição de genes responsáveis pela síntese de proteínas envolvidas na resposta inflamatória.

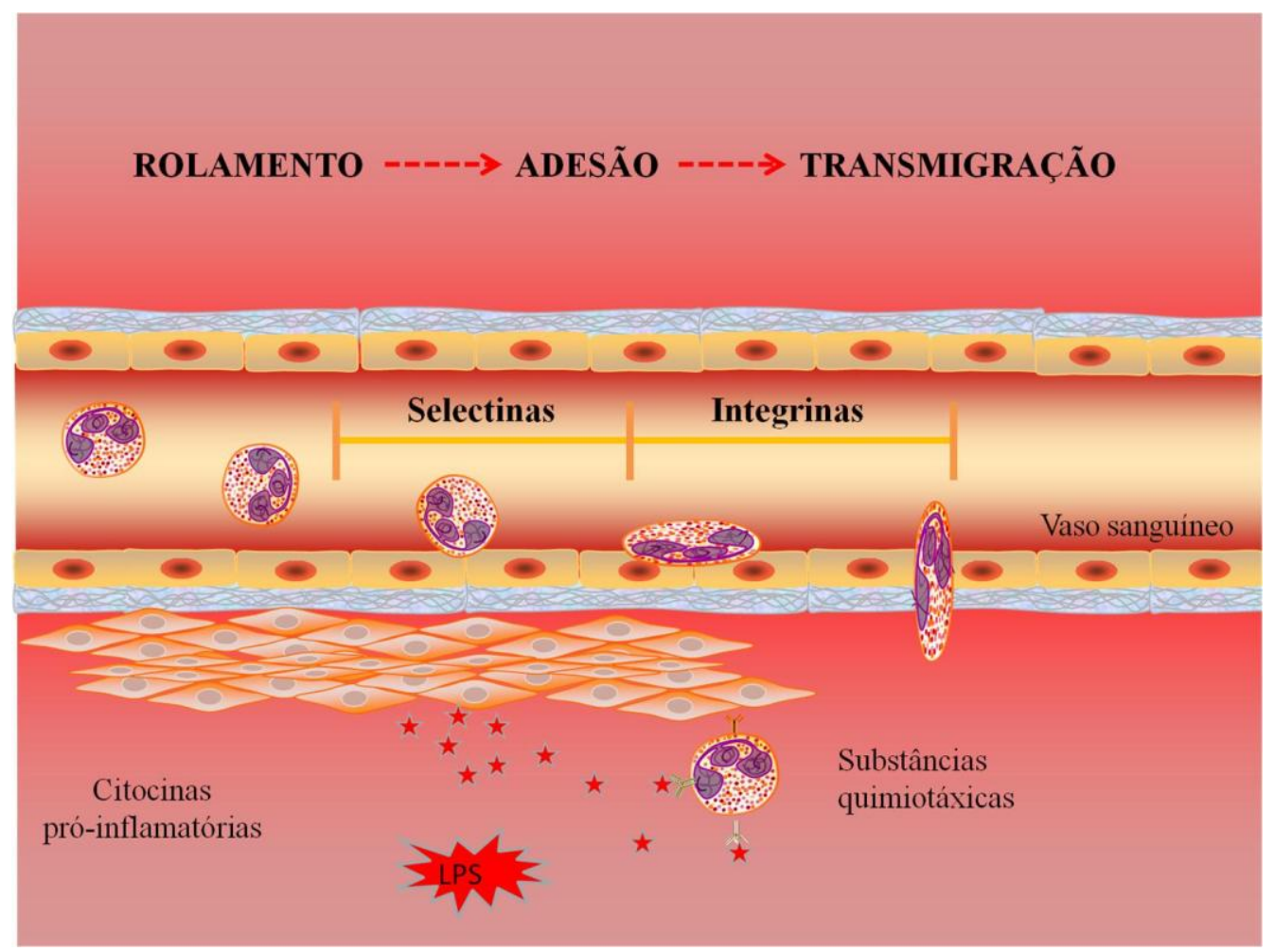

Figura 1: Migração de neutrófilos. Os leucócitos circulantes marginalizam e transmigram de acordo com estímulos nocivos. Por exemplo, após ativação por LPS, neutrófilos que circulam no centro da corrente sanguínea marginalizam, rolam e aderem na camada endotelial, antes de transmigrarem para o tecido. Estes eventos são mediados por interação entre moléculas de adesão expressas na membrana plasmática dos neutrófilos e das células endoteliais ativadas. O processo de rolamento é mediado por moléculas de adesão da família das selectinas que apresentam uma força fraca de ligação permitindo que os neutrófilos rolem pela parede do vaso. Após o rolamento, os neutrófilos passam a interagir com o endotélio através de integrinas e imunoglobulinas, responsáveis pela firme adesão dos neutrófilos ao endotélio e sua posterior migração para o tecido acometido. A liberação de moléculas quimiotáxicas pelo tecido lesado faz com que estas células migrem diretamente para o alvo da lesão. 
Dependendo do tipo de tecido e de estimulo inflamatório, diferentes subconjuntos de moléculas de adesão celular podem ser envolvidos no processo. $\mathrm{Na}$ fase inicial da inflamação, ocorre uma desaceleração transitória de neutrófilos nas vênulas pós-capilares, mediada por moléculas de adesão da família das selectinas, das quais existem três descritas. A L-selectina presente em leucócitos, as P-selectinas presentes em células endoteliais e plaquetas, e as E-selectinas presentes apenas em células endoteliais. Estas moléculas possuem um papel sequencial no rolamento de neutrófilos (Eppihimer et al., 1996) e possuem uma força de ligação fraca, permitindo assim o arraste dos neutrófilos rolando sobre o endotélio. Posteriormente, a "aderência firme" de neutrófilos à parede do vaso ocorre através da interação de integrinas CD11/CD18 ( $\beta 2$-integrinas) com ligantes endoteliais como a molécula de adesão intracelular tipo 1 (ICAM-1). Esta etapa requer ativação de CD11/CD18 vinculada à exposição dos neutrófilos a uma variedade de moléculas quimiotáxicas, como fator de ativação plaquetário ou IL-8. Por último, ocorre a transmigração dos neutrófilos para os tecidos, um processo que exige tanto um estímulo quimiotáxico quanto o empenho das moléculas de adesão de células endoteliais e plaquetas tipo 1 (PECAM-1).

Estudos em que estas moléculas de adesão foram nocauteadas confirmam diversos papeis funcionais, como na montagem da resposta inflamatória podendo torná-las alvos importantes para o desenvolvimento de novas terapêuticas conta, por exemplo, o choque séptico. Em camundongos nocauteados para a molécula PECAM1 e expostos ao LPS de maneira sistêmica, foi observado que estes foram mais sensíveis ao LPS do que os camundongos selvagens, apresentando um aumento da permeabilidade vascular causando uma perda exagerada do volume sanguíneo e queda brusca da pressão arterial (Maas et al., 2005). No caso de camundongos nocauteados para a molécula ICAM-1 e expostos a uma injúria (queimadura) apresentaram uma inflamação pulmonar (quantidade de neutrófilos) significativamente menor quando comparados com camundongos selvagens, indicando um papel fundamental na inflamação (Bird et al., 2010). Estudos deste tipo demonstram que o bloqueio das moléculas de adesão pode efetivamente inibir a montagem de uma resposta inflamatória. Apesar de não ser do escopo desta dissertação é preciso registrar que o padrão de moléculas de adesão pode variar de acordo com o tipo de inflamação (Albelda et al., 1994). 


\subsubsection{Fator de transcrição NFKB}

O fator de transcrição NFKB (do inglês nuclear factor kappa B), compreende uma família de proteínas que atuam sob a forma de dímeros que quando ligados à proteína inibitória kappa B (IKB), é mantido no citoplasma. A ativação deste fator requer a degradação da proteína inibitória, tornando disponível o sítio de sinalização (sigla em inglês NLS) para que haja a translocação nuclear deste fator.

As proteínas NFKB são divididas em dois grupos, um que contém domínio transativador (sigla em inglês TAD), responsável pela indução da transcrição gênica e outro cujos componentes não possuem esta sequência. São conhecidas duas proteínas que não contém TAD (p50 e p52) e cinco que contém TAD (RelA, RelB, cRel, p100 e p105) (Baeuerle e Baltimore, 1996). Os dímeros formados a partir de proteínas que contém TAD regulam positivamente a transcrição dos genes alvos, enquanto que as que não contém TAD bloqueiam esta transcrição.

No caso da resposta inflamatória aguda há ativação do dímero p50/RelA, que induz um pacote de genes responsáveis por esta resposta (Ghosh e Hayden, 2008). Entre estes encontram-se genes que codificam moléculas de adesão, citocinas, enzimas responsáveis por produção de oxigênio livre e de óxido nítrico (NO). Todas estas substâncias são importantes para o combate do agente agressor. Além disso, o gene que codifica a proteína IKB, que mantém os dímeros sequestrados no citoplasma também é controlado por NFKB. Neste caso, é uma transcrição tardia e é considerado um dos fatores importantes para o encerramento da resposta. Em suma, este importante fator de transcrição é responsável pelo desencadeamento da resposta de defesa e por seu término (Ghosh e Hayden, 2008).

O NFKB está presente em diversos tipos celulares. Sua via de sinalização é ativada por diferentes estímulos, sendo que os principais são: citocinas como o TNF e interleucinas como a IL-1 $\beta$ e a IL-2, fatores de crescimento, sinalizadores de apoptose e de proliferação celular (Ghosh e Karin, 2002), bem como por lipopolissacarídeos (LPS) (Akira e Takeda, 2004). Em células imunocompetentes, a ativação da via do NFKB induz a transcrição de citocinas pró-inflamatórias, de moléculas de adesão VCAM-1 e ICAM-1, de enzimas como a sintase de óxido nítrico induzida (iNOS) e a ciclooxigenase (COX). Todos exercem papel importante durante a montagem de uma resposta inflamatória (O’Neill e Kaltschmidt, 2007). Apesar de tudo isso, para tantos 
estímulos, existem apenas três diferentes vias de sinalização de NFKB. Em resumo, esta via de sinalização é central na mediação de uma resposta inflamatória aguda.

\subsection{LIPOPOLISSACARÍDEO (LPS) COMO INDUTOR DA INFLAMAÇÃO AGUDA.}

O LPS é um lipopolissacarídeo de bactérias Gram negativas constituído por uma porção lipídica (lipídio A) e por duas cadeias de açúcar. A porção lipídica interage com receptores de membrana TLR4 (do inglês, "Toll-like receptor 4") (Akira e Takeda, 2004). A ativação destes receptores desencadeia a via de transcrição do NFKB que, como dito anteriormente, é central no desenvolvimento de uma resposta imune inata (Kawai e Akira, 2006; Carmody e Chen, 2007; Lu et al., 2008). Quando injetado localmente LPS aumenta o rolamento, adesão, e a migração de neutrófilos devido ao aumento da expressão de moléculas de adesão (Andonegui et al., 2002). Este aumento induzido por LPS não ocorre em camundongos "knockout" para TLR4 e CD14 (Andonegui et al., 2002). Foi verificado em nosso laboratório que a ativação da via NFKB em células endoteliais, mantidas em cultura, induzida por LPS promove a expressão de iNOS e de NO (Tamura et al., 2009).

\subsection{MELATONINA}

Embora a glândula pineal seja conhecida a mais de 2000 anos, somente nos últimos 50 anos foram divulgados relatos sobre suas funções. Em 1958, o grupo de pesquisadores liderados por Aaron B. Lerner isolou a partir da glândula pineal de bovinos uma substância ativa que quando injetada na pele de anfíbios promovia a mudança de coloração causada pela agregação de melanina dentro dos melanóforos desses animais (Lerner et al., 1958). Dessa forma, caracterizou-se tal substância ativa como melatonina (N-acetil-5-metoxi-triptamina). Desde então houve grande interesse nos estudos dessa substância, abrindo campo para diversas linhas de pesquisas. 
Contudo, muitas funções da glândula pineal e da melatonina ainda continuam a ser descobertas (Karasek e Winczyk, 2006).

A melatonina é um hormônio produzido pela glândula pineal na fase de escuro do ciclo claro/escuro ambiental, possuindo um ritmo de liberação bem definido. Este hormônio vem sendo bem estudado durante as últimas décadas e já se sabe que também pode ser produzido por outras células e tecidos participando de diversas funções fisiológicas e fisiopatológicas. Sua função mais conhecida é como "marcador do tempo", indicando ao organismo as fases do dia e da noite e também das estações do ano. O papel da melatonina como "molécula fotoperiódica" foi caracterizado em estudos sobre a reprodução sazonal de algumas espécies, embora a sua influência reguladora em humanos continue sob investigações.

Estudos experimentais acerca de suas propriedades citoprotetoras indicam que a melatonina tem um potencial para ser usada como medicamento no tratamento de doenças neurodegenerativas como doença de Alzheimer, esclerose lateral amiotrófica e isquemia cerebral. A melatonina ainda possui propriedades oncostáticas, e também atua no sistema imunológico (Pandi-Perumal et al., 2006). Nos últimos anos, estudos acerca de suas funções mostraram que a melatonina é um eficaz antioxidante, atuando como um sequestrador de radicais livres presentes no organismo, bem como regulando várias enzimas antioxidantes (Poeggeler et al., 1994; Esposito et al., 2008).

\subsubsection{Produção e regulação da liberação de melatonina}

Um relógio endógeno que marque o tempo mesmo na ausência dos ciclos exógenos é importante na adaptação dos seres vivos às variações ambientais. Esses ritmos têm influência sobre funções bioquímicas, psíquicas e/ou fisiológicas do organismo. Desta forma, os ritmos biológicos circadianos não ocorrem como uma resposta direta às informações do meio, mas sim por controle de um relógio endógeno, que é sincronizado com as variações do ambiente (Roenneberg e Merrow, 2002). Indivíduos que possuem danos no relógio endógeno central (núcleos supraquiasmáticos - NSQ) podem tornar-se arrítmicos e adquirir distúrbios do sono 
(Hastings et al., 2007), além de apresentar diminuição de atividade reprodutiva (Beaver et al., 2002).

Nos mamíferos existe uma projeção neural que vai da retina ao NSQ e, quando a retina recebe iluminação, o ritmo do relógio é ajustado. Quando a luz incide em fotorreceptores da retina (chamados melanopsina), ativa neurônios que se projetam sobre o NSQ. Estes neurônios formam a via retino-hipotalâmica. O NSQ, por sua vez, projeta-se para outro núcleo hipotalâmico, o chamado núcleo paraventricular (NPV). A luz estimula o NPV através de neurônios que liberam o neurotransmissor ácido gama-aminobutírico (GABA), que silencia este núcleo. No escuro, os neurônios do NSQ são ativados liberando sobre o NPV o neurotransmissor glutamato, que excita outros neurônios desencadeando uma resposta. Esta resposta segue pela medula e ativa o gânglio cervical superior. Este é um gânglio simpático que estimula a glândula pineal. A glândula pineal libera o hormônio melatonina, que sinaliza ao organismo que está escuro. (para revisar, Simonneaux e Ribelayga, 2003)

A produção de melatonina pela pineal é regulada pelo relógio central e a duração de sua produção é inversamente proporcional à duração do fotoperíodo, com pico máximo ocorrendo na fase de escuro (Arendt, 1998), independentemente de os animais apresentarem atividade diurna ou noturna (Simonneaux e Ribelayga, 2003).

$\mathrm{Na}$ fase de escuro, a noradrenalina liberada pelos terminais nervosos simpáticos é o sinal neuroendócrino que leva à indução da transcrição gênica da enzima arilalquilamina-N-acetiltransferase (AA-NAT) (Klein et al.,1997) levando à síntese de melatonina. (Gerdin et al., 2004). Este complexo sistema pode ser observado na figura 2. Como a estimulação simpática da glândula é bloqueada pela luz, o hormônio melatonina sintetizado pelas glândulas pineais de vertebrados é também chamado de hormônio do escuro. Reiter em 1983 caracterizou a melatonina como um relógio e um calendário visto que sendo sintetizada apenas no escuro, informa ao organismo a alternância entre o dia e a noite; e tendo a duração de sua produção aumentada nas noites longas, permite que o organismo diferencie o inverno do verão.

Atualmente sabe-se que a melatonina também pode ser produzida por outras células e tecidos, como a retina, ou atuando como um hormônio de ação local, não necessariamente de maneira rítmica, como nos casos da medula óssea (Tan et al., 1999), trato gastrintestinal de ratos (Bubenik et al., 1992), células imunocompetentes 
(Carrillo-Vico et al., 2004; Pontes et al., 2006), além de fígado, rim e baço de roedores e primatas (Menendez-Pelaez et al., 1993).

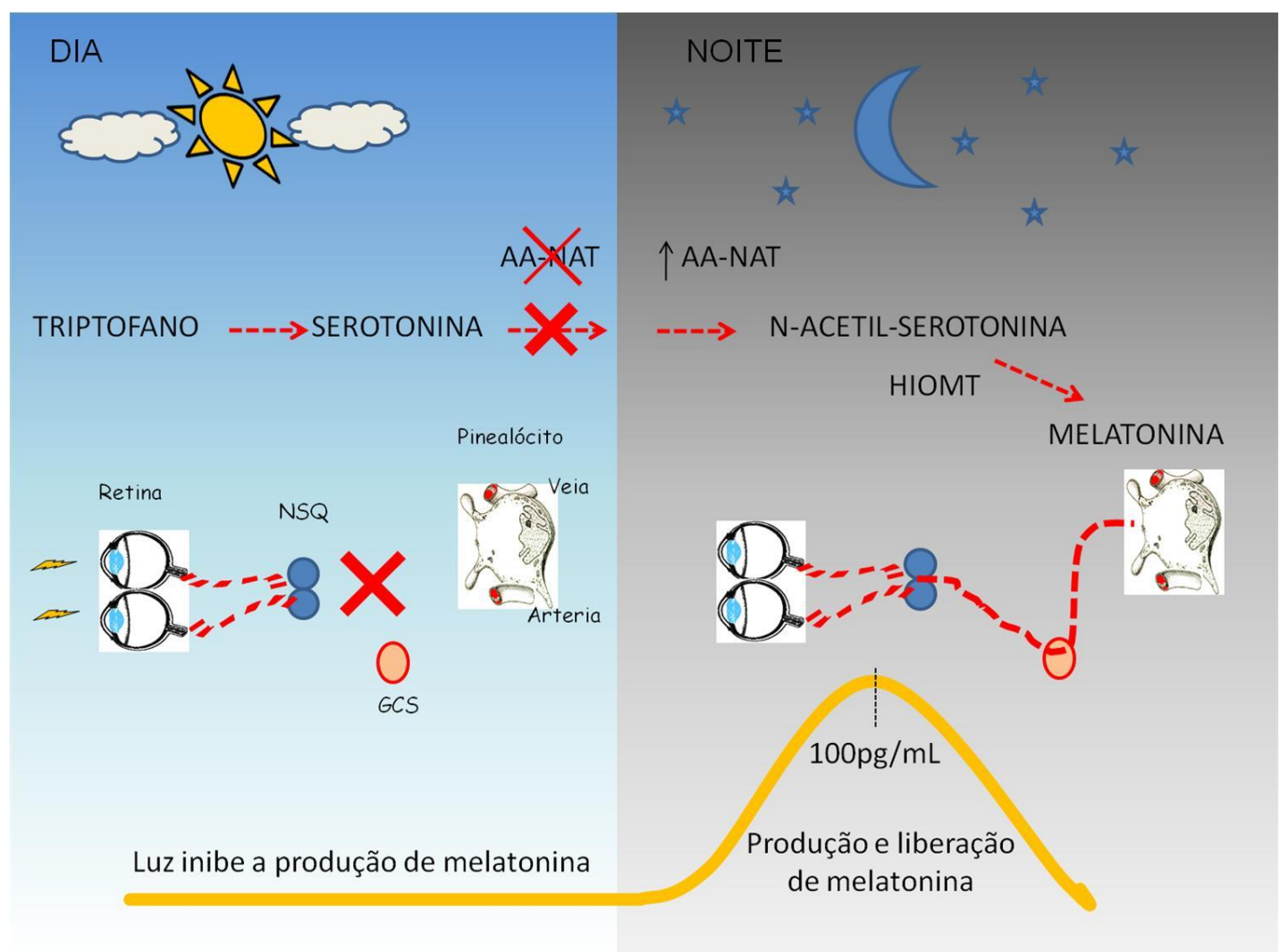

Figura 2: Modulação da produção e liberação de melatonina pela glândula pineal: Neurônios cujos corpos celulares estão na retina projetam-se para os núcleos supraquiasmáticos (NSQ) do hipotálamo que, através de uma via polissináptica, atinge o glânglio cervical superior. A partir daí fibras simpáticas projetam-se para a pineal e a ativação de adrenoceptores nos pinealócitos leva à transcrição do gene da enzima AA-NAT. Durante o dia (lado esquerdo) a luz impede a ativação do NSQ. No escuro (lado direito) esta via neuronal é ativada levando à produção de melatonina. A melatonina é o hormônio que marca o escuro.

AA-NAT $=$ arilalquilamina $\mathrm{N}$ acetiltransferase; HIOMT= hidroxi-indol-O-metiltransferase; GCS= gânglio cervical superior.

\subsubsection{Biossíntese da melatonina}

A melatonina é uma substância altamente conservada nos reinos animal e vegetal. A produção da melatonina na glândula pineal é feita pelos pinealócitos.

A biossíntese da melatonina tem início com a formação e absorção do aminoácido triptofano. O triptofano é convertido em 5-hidroxi-triptofano (5-HTP) 
pela enzima triptofano hidroxilase 1 que é então descarboxilado pela enzima 5-HTP descarboxilase formando a serotonina (5-hidroxi-triptamina ou 5-HT). Em seguida, ocorre a $\mathrm{N}$-acetilação da serotonina transformando-a em N-acetilserotonina (NAS), através da enzima arilalquilamina $\mathrm{N}$-acetiltransferase (AA-NAT), enzima chave na síntese da melatonina. Esta é a enzima regulada pela luz através de uma via polissinátpica. O passo final da via é a metilação de NAS em melatonina, através da enzima hidroxi-indol-orto-metiltransferase (HIOMT) (figura 3). Esta é a enzima que tem a menor velocidade de reação e portanto, deve ser considerada responsável pelo passo limitante na síntese de melatonina. No entanto, do ponto de vista fisiológico a enzima chave é a AA-NAT porque tem sua síntese e atividade reguladas pela luz. Após sua síntese, a melatonina é liberada na circulação sanguínea e no líquor (Markus et al., 2003; Claustrat et al., 2005; Reiter et al., 2010).

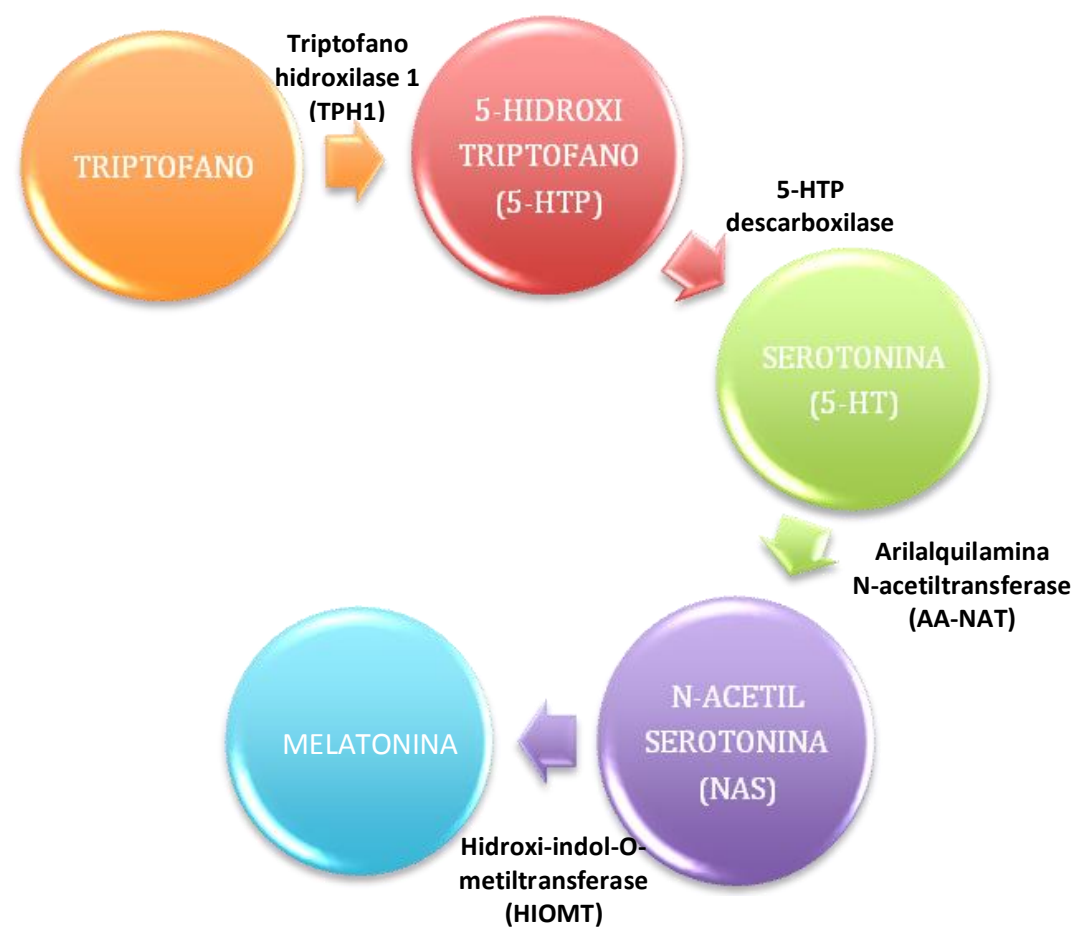

Figura 3: Biossíntese de melatonina a partir do aminoácido triptofano. O triptofano é convertido em 5-hidroxi-triptofano (5-HTP) pela enzima triptofano hidroxilase 1 que é então descarboxilado pela enzima aminoácido aromático descarboxilase formando a serotonina (5-hidroxi-triptamina ou 5-HT). Em seguida ocorre a $\mathrm{N}$-acetilação da serotonina transformando-a em $\mathrm{N}$-acetilserotonina (NAS), através da enzima arilalquilamina $\mathrm{N}$-acetiltransferase (AA-NAT), enzima chave na síntese da melatonina. Por fim, ocorre a metilação de NAS em melatonina, através da enzima hidroxi-indol-orto-metiltransferase (HIOMT). Após isso a melatonina é liberada na circulação sanguínea. (Reiter et al., 2010) 
A produção normal de melatonina pode ser alterada por vários fatores como: patologias cardiovasculares, hipertensão e isquemia (Paulis e Simko, 2007) e também em pacientes que sofreram paratireoidectomia. Estes pacientes apresentaram um aumento da secreção noturna de melatonina (Kancheva et al., 2008), demontrando uma relação entre pineal e glândula paratireóide.

\subsubsection{Mecanismos de ação da melatonina}

A melatonina tem a capacidade de atravessar facilmente a membrana das células, pois possui um alto coeficiente de partição óleo/água (Shida et al., 1994). Por conta desta característica, a melatonina possui vários alvos intracelulares, indicando que sua ação biológica também acontece em vários níveis diferentes, através da interação com receptores, enzimas e outras proteínas, tendo como consequência uma grande diversidade de efeitos (Costa et al., 1995; Markus e Tamura, 2009). A melatonina exerce alguns de seus efeitos através da ligação com alta afinidade a um grupo de receptores acoplados à proteína G. Assim, a presença desses receptores faz com que não sejam necessárias concentrações altas de melatonina para haver uma resposta fisiológica.

Os sítios de ligação para melatonina estão presentes em várias regiões do organismo, por exemplo, no sistema nervoso central, artérias cerebrais, em diversos tecidos periféricos, como nas glândulas adrenais, glândulas mamárias, no trato gastrointestinal, nos órgãos linfóides primários e secundários, coração, dentre outros. (Vanecek, 1988; Carneiro et al., 1993; Ekmekcioglu et al., 2001; Ekmekcioglu et al., 2003)

Os mecanismos de ação da melatonina variam de acordo com o modelo estudado e, principalmente, de acordo com a concentração de melatonina necessária para obtenção de seus efeitos (Markus e Tamura, 2010). Por este motivo os inúmeros mecanismos de ação possíveis tem sido um grande desafio para o estudo dos efeitos fisiológicos da melatonina. 


\subsubsection{Receptores de melatonina}

Receptores de membrana de melatonina foram inicialmente definidos em função das suas características farmacológicas e cinéticas. Os conhecidos têm sete domínios transmembrânicos e fazem parte da superfamília dos receptores acoplados à proteína G (Reppert, 1997).

De acordo com as normas de nomenclatura descritas pela IUPHAR (“International Union for Pharmacology"), inicialmente foram descritos dois tipos de receptores para melatonina, classificados como ML1 ou ML2, de acordo com as diferenças farmacológicas da ligação à 2-[ $\left.{ }^{125} \mathrm{I}\right]$-iodomelatonina. Os sítios de ligação do tipo ML1 foram clonados e pertencem à família de receptores acoplados à proteína G, enquanto os sítios de ligação para ML2 ainda não foram clonados, dificultando sua localização. Os receptores ML1 agem principalmente inibindo a formação de AMPc, sendo esta inibição sensível à toxina pertussis, sugerindo um receptor acoplado à proteína $\mathrm{G}_{\mathrm{i}} / \mathrm{G}_{\mathrm{o}}$ (Dubocovich, 1988).

No final da década de 90, foram identificadas três isoformas de receptores, MEL1a, MEL1b e MEL1c, associadas aos sítios de ligação do tipo ML1, sendo aceitas como uma via importante de transdução da informação trazida pela melatonina e expressos em locais diferenciados. Os receptores MEL1a são observados no hipotálamo, NSQ e hipófise tuberalis de uma variedade de animais, incluindo o homem, assim como os receptores MEL1b são expressos na retina e cérebro de mamíferos, enquanto os receptores MEL1c não apresentam expressão em mamíferos, sendo descritos apenas em anfíbios, peixes e aves (Reppert, 1997). Posteriormente, as nomenclaturas utilizadas para os subtipos de receptores foram modificadas pela IUPHAR, o primeiro receptor clonado, MEL1b, passou a ser chamado $\mathrm{MT}_{2}$, os receptores MEL1a passaram a $\mathrm{MT}_{1}$ e os do subtipo $\mathrm{ML}_{2}$ passaram a ser denominados $M T_{3}$ (Dubocovich et al., 2000). A IUPHAR apenas classifica receptores de mamíferos, por isso o receptor MEL1c não possui novo nome.

Os receptores para melatonina clonados até o momento $\left(\mathrm{MT}_{1}\right.$ e $\left.\mathrm{MT}_{2}\right)$, sensíveis à toxina pertussis, promovem a redução dos níveis de AMP cíclico por inibir a enzima adenilil ciclase. No entanto, considerando-se que nos últimos anos tem sido demonstrado que subunidades $\beta \gamma$ acopladas à proteína $G_{i}$ podem ativar fosfolipase $\mathrm{C}$ (da sigla em inglês PCL), levando à liberação de cálcio do retículo, este 
mecanismo, ainda que não demonstrado, também poderia teoricamente contribuir para a resposta dos receptores de melatonina dos subtipos $\mathrm{MT}_{1}$ e $\mathrm{MT}_{2}$. (Markus et al., 2003).

A clonagem de receptores de melatonina a partir de cDNA, resultou no desenvolvimento de linhagens recombinantes. Quando os receptores de melatonina humanos foram clonados $\left(\mathrm{hMT}_{1}\right.$ e $\left.\mathrm{hMT}_{2}\right)$ e expressos em uma variedade de células, demonstrou-se sua ação inibitória sobre a formação de AMPc induzida por forskolina (Reiter, 2003).

Os mecanismos de ação dos receptores $\mathrm{MT}_{1}$ e $\mathrm{MT}_{2}$ são dependentes do local em que se encontram, já que apresentam uma grande variedade de vias celulares descritas, como ativação da PCL, levando a uma cascata de sinalização que resulta no aumento da concentração intracelular de cálcio. Também existem ações diretas e/ou indiretas sobre a regulação de canais na membrana, além da regulação da enzima adenilil-ciclase, resultando na modulação da concentração de AMPc (Masana e Dubocovich, 2001).

Além do ritmo de síntese de melatonina, a densidade de receptores também apresenta variação rítmica. No núcleo supraquiasmático e na pars tuberalis da hipófise a densidade de proteína e de RNAm para receptores de melatonina apresenta uma variação com o ciclo claro/escuro ambiental. No caso da pars tuberalis da hipósife foi evidente que este ritmo é devido a uma ação da melatonina sobre o próprio sistema receptor (Guerrero et al., 2000).

É importante ressaltar que as ações da melatonina podem ocorrer via diferentes sistemas de recepção, tais como receptores de membrana e processos bioquímicos intracelulares. O próprio sistema de recepção pode variar ao longo do dia, conferindo outra forma de modulação das funções fisiológicas (Markus et al., 2003).

Nosjean e colaboradores (2000) purificaram o receptor de melatonina $M T_{3}$ a partir do rim de hamster sírio e apresentaram sua posterior identificação como sendo homólogo à quinona redutase 2 (QR2) no homem, além de possuírem uma localização intracelular. A enzima QR2 foi caracterizada como apresentando 95\% de similaridade, com base em sequência humana, com 57 dos 71 aminoácidos idênticos ao do receptor $M T_{3}$. O análogo da molécula de melatonina, 5-metoxicarbonilaminoN-acetil-triptamina (5-MCA-NAT) se liga seletivamente a sítios $M T_{3}$ em rins, 
testículos e cérebro de hamster, mas não é capaz de ligar a sítios $\mathrm{MT}_{1}$ em retina de aves (Dubocovich, 1985).

\subsubsection{Ações intracelulares da melatonina}

Um dos efeitos mais conhecidos e bem estudados de altas concentrações de melatonina é a capacidade de atuar como antioxidante. Os radicais livres possuem alta reatividade, o que leva à oxidação de moléculas estruturais e essenciais para a atividade celular. Estudos apontam que a melatonina e moléculas afins têm propriedades de sequestrar radicais livres, podendo neutralizar e reduzir a concentração dos mesmos em sistemas biológicos e químicos. Além de uma ação antioxidante direta, a melatonina é capaz também de agir sinergicamente com outros antioxidantes conhecidos, tais como vitamina E e ácido ascórbico (Reiter, 1995; Tan et al.,2003).

A produção de melatonina diminui gradativamente com a idade e, da mesma forma, os efeitos dos radicais livres também estão envolvidos com o envelhecimento. Estudos realizados por Reiter (1995) têm sugerido que a concentração de melatonina mantida em um nível elevado poderia retardar o envelhecimento e as alterações relacionadas ao câncer. Além disso, a melatonina tem sido descrita como um potente suplemento antioxidante no tratamento de câncer, podendo proteger contra danos celulares causados por agentes cancerígenos (Reiter et al., 1997).

É notório que a maior parte dos efeitos farmacológicos da melatonina necessite de altas doses, enquanto as concentrações plasmáticas estão presentes no intervalo picomolar, porém estudos realizados por Benot e colaboradores (1999) sugerem que a melatonina poderia exibir propriedades antioxidantes mesmo em níveis fisiológicos.

Por se tratar de uma molécula anfipática, como já dito, a melatonina também possui ações intracelulares e um dos principais mecanismos de ação observados em baixas concentrações é a capacidade de ligação à calmodulina, ligação esta de alta afinidade, sugerindo uma relevância fisiológica (Benítez-King et al., 1991; BenítezKing e Antón-Tay , 1993). Benítez-King e Antón-Tay (1993) analisaram dados 
relacionando a interação da melatonina com a calmodulina e demonstraram que sua interação pode permitir a modulação rítmica de muitas funções celulares. Considerando que a calmodulina participa da maioria dos eventos intracelulares em vertebrados superiores, por possuir capacidade de ligação e regulação em uma grande diversidade de proteínas-alvos, incluindo enzimas, canais iônicos, receptores e proteínas do citoesqueleto, a interação melatonina-calmodulina pode interferir em diversas modificações de funções celulares. A melatonina inibe a atividade da adenilil-ciclase dependente de cálcio-calmodulina em miotubos de rato em cultura e da isoforma constitutiva da sintase do óxido nítrico em cerebelo de ratos (Pozo et al., 1997; De Almeida-Paula et al., 2005)

Os processos dependentes de calmodulina podem ser modulados pela disponibilidade de cálcio, por antagonistas da calmodulina e por modificações póstransducionais, como sua própria fosforilação. A melatonina é um antagonista endógeno da calmodulina. Soto-Vega e colaboradores (2004) caracterizaram a fosforilação da calmodulina por PKC- $\alpha$ e sua estimulação por melatonina in vitro, reconstituindo em um sistema enzimático, onde a melatonina aumenta a fosforilação de calmodulina e PKC- $\alpha$.

Além dos efeitos cronobióticos, oncostáticos e antioxidantes, a melatonina atua também promovendo efeitos no sistema imunológico, regulando a expressão de vários genes imunomoduladores de citocinas incluindo TNF, bem como os níveis de IL-1 $\beta$ e interferon gamma (INF $\gamma$ ) (Liu et al., 2001).

\subsection{MELATONINA NA INFLAMAÇÃO}

A interação entre o sistema neuroendócrino e o sistema imunológico é essencial para a resposta adaptativa de um organismo contra os desafios ambientais. Neste contexto, a pineal e seu neurohormônio melatonina desempenham um papel importante, sendo um dos responsáveis por manter a homeostase interna em vertebrados (Maestroni, 2001; Skwarlo-Sonta, 2002). Nosso laboratório vem desenvolvendo desde 2007 o conceito do "eixo imune-pineal" (Markus et al., 2007). A pineal responderia à citocinas e hormônios ligados a resposta imune e as células 
imunocompetentes seriam alvos da melatonina. Este conceito ainda foi ampliado para mostrar que em determinadas condições especiais, como durante a montagem da resposta inflamatória, a melatonina passaria a ser produzida por células imunocompetentes (Markus e Ferreira, 2011).

$\mathrm{O}$ primeiro relato sobre a interação entre a glândula pineal e o sistema imunológico descreve uma desorganização do timo em ratos pinealectomizados no primeiro dia de vida (Csaba et al., 1965). Vários aspectos da reação imunológica, como número de células e suas subpopulações, proliferação dos linfócitos, níveis plasmáticos de diferentes citocinas e índice fagocítico, exibem pronunciada ritmicidade (Petrovsky e Harrison, 1997).

Alterações diurnas e sazonais da atividade do sistema imunológico são controladas pelas concentrações de melatonina plasmática, que é uma função da secreção pineal (Skwarlo-Sonta et al., 2003). Por outro lado, células imunocompetentes como linfócitos e fagócitos são fontes de melatonina (CarrilloVico et al., 2004, Pontes et al., 2006). Já foi demonstrado que os linfócitos dispõem de toda a maquinaria necessária para sintetizar melatonina. Portanto, a melatonina pode ter uma ação parácrina ou autócrina independente da produção pineal (CarrilloVico et al., 2004).

A melatonina induz a produção de interleucina 2 (IL-2) em linfócitos ativados. Este efeito é mediado por receptores de membrana de melatonina, visto que o luzindol, bloqueador não seletivo de receptores de melatonina MT1 e MT2, bloqueia a produção de IL-2 por linfócitos ativados (Lardone et al., 2009). Por outro lado, a melatonina produzida pela pineal também é capaz de modular os níveis plasmáticos de IL-2, IL-6 e IL-12. O acompanhamento das concentrações plasmáticas de melatonina e IL-2 no plasma de mulheres que sofreram cesariana mostra que até 15 dias após a cirurgia, quando a produção noturna de melatonina está abolida, não há ritmo de IL-2. Após o $15^{\circ}$ dia ocorre a volta do ritmo diário de IL-2, com maiores concentrações à noite, que é simultânea ao aumento da concentração noturna de melatonina (Pontes et al., 2007). Certamente, estes dados recentes que demonstram o mecanismo de controle de produção de IL-2 por melatonina devem ser base para os achados de Maestroni, revistos há dez anos (Maestroni, 2001), que propunha que melatonina exerce uma ação auxiliadora do sistema imune em animais e seres humanos. 
Em 2007, o nosso grupo propôs a existência de uma relação coordenada entre a produção de melatonina pela glândula pineal e pelas células imunocompetentes e que esta última é dependente da sinalização de padrões moleculares associados a patógenos e de citocinas e hormônios envolvidos na resposta imunológica (Markus et $a l ., 2007)$. Esta conversa cruzada foi denominada de eixo imune-pineal (figura 4).

Durante o estudo dos efeitos da melatonina sobre a migração de leucócitos in vivo foi observado que esta indolamina reduzia em $50 \%$ o rolamento e a adesão de leucócitos à parede endotelial de vênulas pós-capilares de ratos com altíssima eficácia (Lotufo et al., 2001). A concentração efetiva para a redução de $50 \%$ do rolamento estava na faixa de $\mathrm{pM}$ e da adesão, na faixa de nM. Portanto, concentrações encontradas no plasma à noite levariam a uma diminuição da quantidade de células capazes de migrar para o tecido. Como os estudos foram feitos em ratos, foi formulada a hipótese de que na montagem de uma resposta inflamatória, ou resposta imunológica inata, haveria a supressão da produção de melatonina pela glândula pineal, permitindo uma montagem eficiente da resposta inflamatória. Conforme a resposta de defesa prosseguisse, a melatonina produzida pelas células imunocompetentes ativadas teria uma ação parácrina, inclusive reduzindo a migração celular quando esta já não se fizesse tão necessária. Na fase de recuperação, outro grupo de moléculas ou um diferente estado de ativação dos pinealócito, criariam as condições necessárias para a restauração do ritmo diário de melatonina (figura 4).

No momento, vários dos elementos do eixo imune-pineal já estão esclarecidos. Foi demonstrado que LPS e TNF, agindo em receptores localizados nos pinealócitos induzem a translocação do fator NFKB para o núcleo e este é responsável pela inibição da transcrição do gene da AA-NAT (Fernandes et al., 2006, da Silveira Cruz-Machado et al., 2010). Por outro lado, glicocorticoides, atuando diretamente sobre os pinealócitos bloqueiam o efeito do NFKB potenciando a produção de melatonina (Ferreira et al., 2005, Fernandes et al., 2009). Do outro lado do eixo, foi demonstrado que a incubação de fagócitos do colostro humano com bactéria Eschirichia coli, ou zimosan, leva à produção de melatonina (Pontes et al., 2006). 


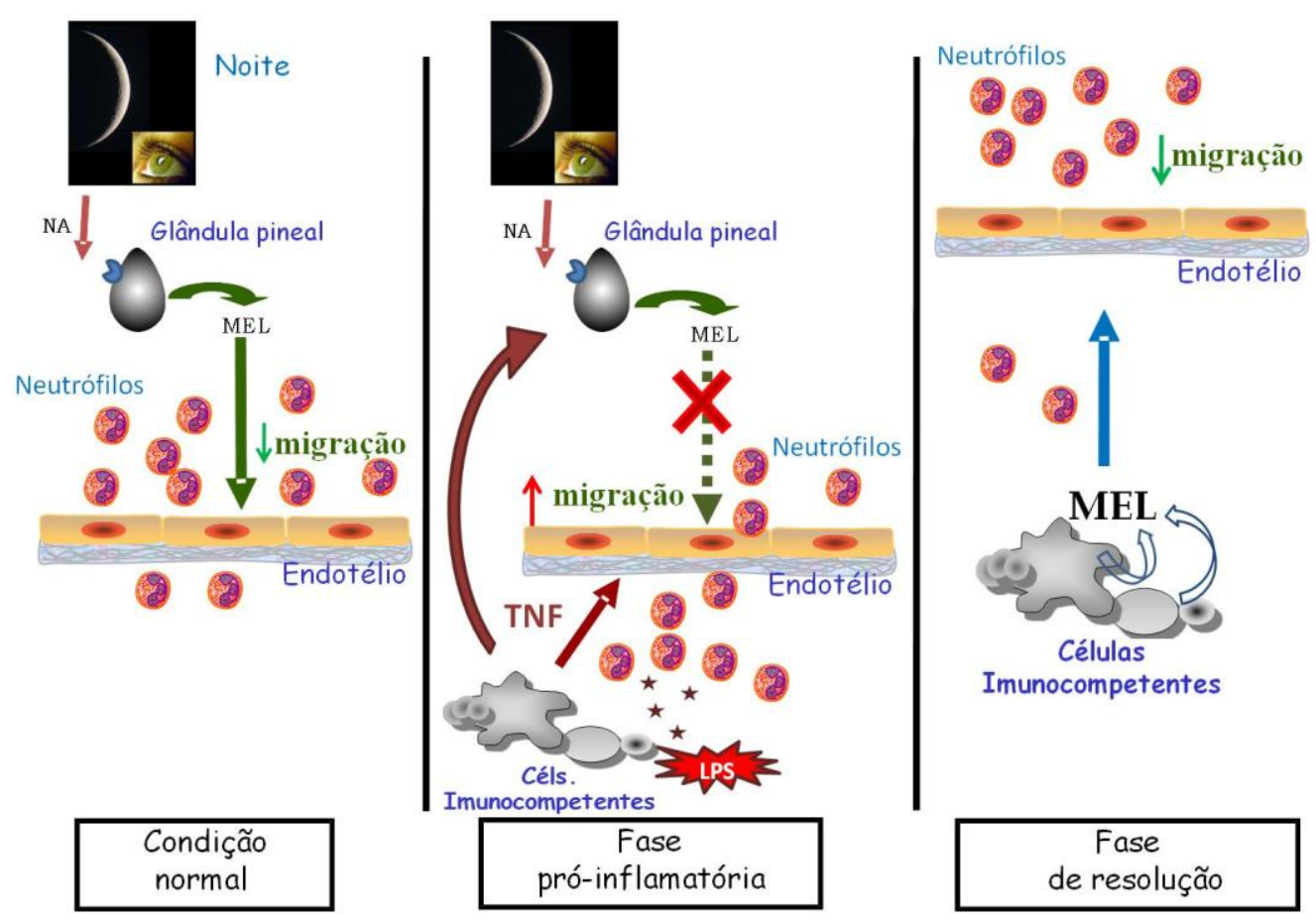

Figura 4: Eixo imune-pineal. Em condições normais, a melatonina liberada pela pineal inibe a migração de neutrófilos sendo esta muito baixa ou inexistente. No começo de uma resposta inflamatória induzida, por exemplo, por LPS, citocinas pró-inflamatórias como o TNF são liberadas na circulação que vão atuar sobre a glândula pineal inibindo a produção de melatonina (fase próinflamatória). Quando a melatonina é bloqueada, seus efeitos antiinflamatórios sobre as células endoteliais não ocorrem. Este bloqueio admite a montagem da resposta inflamatória, permitindo a migração de neutrófilos para o tecido infectado. Na medida em que a inflamação se resolve (fase de resolução), as células imunocompetentes produzem e liberam melatonina localmente. A melatonina presente vai ter uma ação parácrina inibindo migração dos neutrófilos. NA= noradrenalina, MEL= melatonina, $\mathrm{TNF}=$ fator de necrose tumoral, $\mathrm{LPS}=$ lipopolissacarídeo.

Como comentado anteriormente a melatonina é um dos fatores endógenos que controlam a migração de células sanguíneas através da camada endotelial. Certamente, vários outros fatores, tais como os próprios glicocorticoides liberados pela adrenal controlam esta migração celular (Farsky et al., 1995). Desta forma, o endotélio é um alvo direto da modulação hormonal. O entendimento de quais os efeitos ocorrem devido a uma ação da melatonina sobre estas células pode ser alcançado pelo estudo em sistemas isolados. 


\subsection{CONSIDERAÇÕES}

Nesta introdução fica evidente a complexidade dos efeitos da melatonina e a multiplicidade de mecanismos de ação possíveis. Portanto, o estudo dos efeitos da melatonina em modelos bem definidos, certamente facilitará o entendimento de seu efeito em situações fisiológicas e fisiopatológicas. Em consequência, este trabalho teve como objetivo o estudo, em um modelo in vitro de células endoteliais, do efeito da melatonina sobre a expressão de moléculas de adesão na interação neutrófiloendotélio utilizando o LPS como estimulador dessa interação. 


\section{OBJETIVOS}

Caracterizar o efeito da melatonina sobre a interação neutrófilo-endotélio em um sistema in vitro. Para tanto, foi determinado o efeito da melatonina sobre:

$>$ a interação neutrófilo-endotélio induzida por LPS;

$>$ a expressão das moléculas de adesão ICAM-1 e PECAM-1 induzida por LPS. 


\section{MATERIAL E MÉTODOS}

\subsection{ANIMAIS}

Foram utilizados ratos da linhagem Wistar adultos, machos, pesando entre 200 e 300 g (3 meses aproximadamente), provenientes do biotério do Instituto de Biociências - USP. Os animais são mantidos em ciclo claro-escuro de 12/12 horas (luzes acesas às 07h00 e apagadas às 19h00), recebendo ração e água “ad libitum” até o momento do experimento.

A realização dos experimentos foi de acordo com os princípios éticos de utilização de animais. Os protocolos experimentais foram aprovados pela Comissão de Ética no Uso de Animais (CEUA) do Instituto de Biociências da Universidade de São Paulo (protocolo 080/2008).

\subsection{REAGENTES}

Foram utilizados os seguintes reagentes e fármacos:

- Álcool etílico - Merck (São Paulo,SP, Brasil).

- Anticorpo monoclonal de rato para ICAM-1 (CD-54) conjugado à isotiocianato de fluoresceína (FICT) - BD Pharmingen (San Diego, CA, EUA).

- Anticorpo monoclonal de rato para PECAM-1 (CD-31) conjugado à ficoeritrina (PE) - BD Pharmingen (San Diego, CA, EUA).

- Azul de tripan $(0,4 \%)$ - Cellgro (Manassas, VA, EUA)

- EDTA (ácido etileno diamino tetracético) - Sigma-Aldrich (St. Louis, Missouri, EUA).

- Gentamicina - GIBCO BRL Products (Grand Island, NY, EUA). 
- LPS (Escherichia coli, sorotipo 0127:B8) - Sigma-Aldrich (St. Louis, Missouri, EUA).

- Luzindol (N-acetil-2-benzitriptamina) - Sigma-Aldrich (St. Louis, Missouri, EUA).

- Meio de cultura “Dulbecco's Modified Eagle Medium” (DMEM) - GIBCO BRL Products (Grand Island, NY, EUA).

- Melatonina (N-acetil-5-metoxi-triptamina) - Sigma-Aldrich (St. Louis, Missouri, EUA).

- Pancreatina - GIBCO BRL Products (Grand Island, NY, EUA).

- Percoll - Sigma-Aldrich (St. Louis, Missouri, EUA).

- Peróxido de hidrogênio $\left(\mathrm{H}_{2} \mathrm{O}_{2}\right)$ - Invitrogen Life Tecnology (Carlsbad, CA, EUA).

- Soro fetal bovino - GIBCO BRL Products (Grand Island, NY, EUA).

- Tetrametilbenzidina (TMB ) - Sigma-Aldrich (St. Louis, Missouri, EUA).

Todos os reagentes utilizados apresentavam grau de pureza analítico. Melatonina e luzindol foram estocados na concentração de $10 \mathrm{mM}$ em etanol 3\% e $100 \%$, respectivamente. Todos os reagentes restantes foram estocados em $\mathrm{H}_{2} \mathrm{O}$ deionizada e purificada por sistema Milli-Q. Os estoques foram diluídos no dia do experimento.

\subsection{CULTURA DE CÉLULAS ENDOTELIAIS}

Células endoteliais provenientes do músculo cremaster foram isoladas de acordo com o método de Chen e colaboradores, (1995) modificado por Lotufo e colaboradores, (2001). Os ratos foram sacrificados por decaptação. Os animais foram banhados em etanol 70\% e o cremaster retirado em ambiente estéril, lavado em PBS (composição em g/L: $\mathrm{NaCl}$ 7,3; $\mathrm{Na}_{2} \mathrm{HPO}_{4}$ 2,865; $\mathrm{NaH}_{2} \mathrm{PO}_{4}$ 0,276; $\mathrm{KCl}$ 0,3826) e cortados em pequenos pedaços de aproximadamente 2 x $2 \mathrm{~mm}$. Em cada poço de uma placa de 24 poços foram colocados dois pedaços de tecido. Após o tempo necessário para aderir ao fundo (aproximadamente 5 minutos) os tecidos foram cobertos com 
meio de cultura DMEM suplementado com soro fetal bovino (20\%). As placas foram mantidas em estufa $\left(37^{\circ} \mathrm{C}, 5 \% \mathrm{CO}_{2}\right)$ e os tecidos retirados após 48 horas. De acordo com Chen e colaboradores (1995), quando o tecido é incubado por 48 horas, apenas células sanguíneas e células endoteliais migram para a placa. Com as trocas de meio subsequentes, as células sanguíneas são eliminadas. Este procedimento foi comprovado e caracterizado por nosso grupo utilizando marcadores específicos de células endoteliais (anti-fator de Von Willebrand e anti-CD31) (Tamura et al. 2006).

Células endoteliais migradas do tecido foram mantidas no mesmo ambiente até atingir confluência, trocando-se o meio a cada 48 horas. O tempo para atingir a confluência era de aproximadamente 14 dias. As células foram suspensas utilizando a enzima pancreatina $2,5 \mathrm{~g} / \mathrm{mL}$ e utilizadas de acordo com os protocolos descritos a seguir.

\subsection{ENSAIO DE EXCLUSÃO POR AZUL DE TRIPAN}

Para avaliar a proliferação celular foi utilizado o ensaio de exclusão por azul de tripan. A cultura primária foi feita de acordo com protocolo descrito anteriormente. A estratégia experimental está descrita a seguir.

Após entrarem em confluência as células foram replaqueadas na concentração de $10^{4}$ células por poço em sete placas de 24 poços, totalizando 168 poços. Cada placa continha 6 poços com os seguintes tratamentos:

1 - meio de cultura

2 - veículo de melatonina $10^{-4} \mathrm{M}$

3 - melatonina $10^{-4} \mathrm{M}$

4 - melatonina $10^{-9} \mathrm{M}$

$\mathrm{O}$ meio de cultura de cada tratamento era trocado a cada $48 \mathrm{~h}$ e, portanto, as células foram tratadas nos dias zero, 2, 4 e assim sucessivamente até o fim das contagens.

A cada dia, durante 16 dias retiramos três poços de cada tratamento em mesma placa para proceder ao teste de exclusão por azul de tripan (figura 5). Foram colocados $30 \mu \mathrm{l}$ contendo as células em eppendorf na presença de $2 \mu \mathrm{l}$ de solução de 
azul de tripan $(0,4 \%$ em salina). Após 5 minutos transferimos $14 \mu \mathrm{l}$ desta solução contendo as células para câmara de Neubauer onde foi realizada a contagem das células coradas (não viáveis) e não coradas (viáveis). Este experimento foi repetido três vezes, portanto foi feito com culturas de células de três animais distintos.

\section{Dia 0}
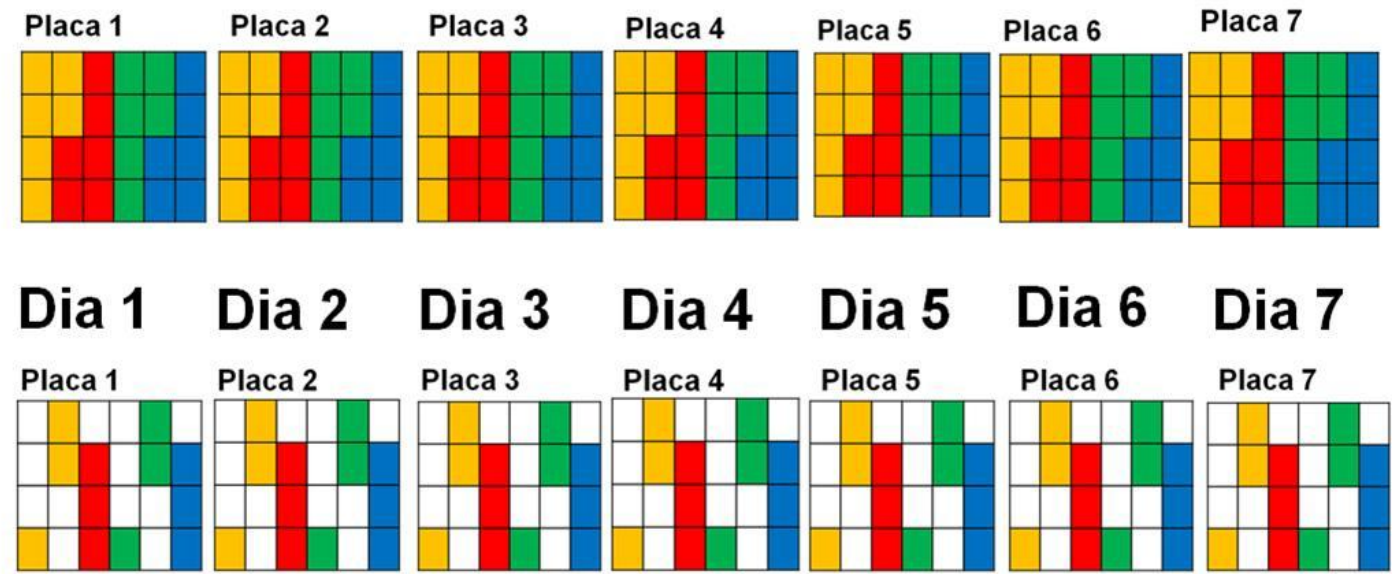

\section{Dia 8 Dia 9 Dia 10 Dia 13 Dia 14 Dia 15 Dia 16}

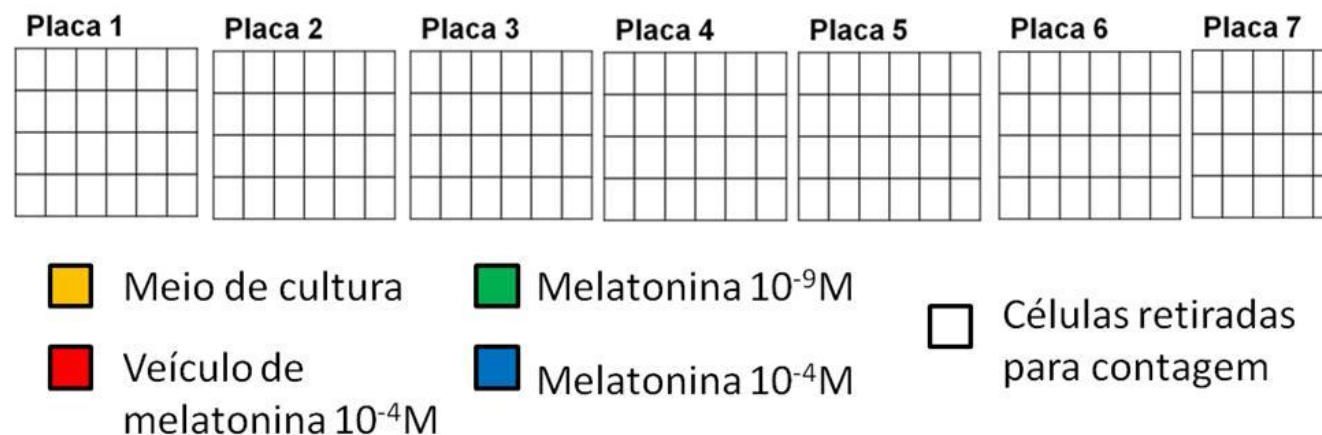

Figura 5: Protocolo de contagem com azul de tripan para avaliar a proliferação das células endoteliais. Após entrarem em confluência, as células foram replaqueadas (dia 0 ) na concentração de $10^{4}$ células por poço em 7 placas de 24 poços, formando quatro grupos distintos: amarelo - meio de cultura, vermelho - veículo de melatonina $10^{-4} \mathrm{M}$, verde - células tratadas com melatonina $10^{-9} \mathrm{M} \mathrm{e}$ azul - células tratadas com melatonina $10^{-4} \mathrm{M}$. A cada dia que se seguiu as células de três poços diferentes de cada grupo tratado foram retiradas para a contagem (branco) em azul de tripan. Cada dia esses poços eram retirados de placas diferentes até terminar as 7 placas. Nos dias 11 e 12 não houve contagem. 


\subsection{ENSAIO DE ATIVIDADE METABÓLICA (MTT)}

$O$ teste de MTT (3-(3-4,5-dimetiltiazol-2yl)-2,5-difenil brometo de tetrazolina), descrito originalmente por Mosmann (1983), foi usado para avaliar a viabilidade celular. Enzimas mitocondriais ativas apenas em células vivas são capazes de transformar o substrato tetrazolínico de cor amarela em formazan, que tem cor azul. Portanto, a leitura espectrofotométrica pode levar a uma avaliação da atividade metabólica das células e com isto permitir inferências sobre a viabilidade celular.

Para avaliar a atividade metabólica das células endoteliais ao longo do tempo foi utilizado o seguinte protocolo: células endoteliais em diferentes concentrações $\left(10^{3}, 5 \times 10^{3}, 10^{4}, 5 \times 10^{4}\right.$ e $10^{5}$ células/poço) foram aplicadas em placas de 96 poços. $\mathrm{O}$ meio era trocado a cada 48 horas e este procedimento foi repetido com células provenientes de três animais diferentes.

O ensaio de MTT foi realizado em células cultivadas por 1, 2, 3 ou 4 dias. No dia do experimento as placas foram centrifugadas a $200 \mathrm{~g}, 4^{\circ} \mathrm{C}$ por 10 minutos. Foi retirado todo o sobrenadante, adicionado $100 \mu \mathrm{l}$ de solução contendo MTT (5 mg/mL) em meio de cultura (na proporção de 1:9) e as placas foram incubadas por 4 horas em estufa $\left(5 \%\right.$ de $\left.\mathrm{CO}_{2}, 37^{\circ} \mathrm{C}\right)$. Após o período de incubação foi adicionado $100 \mu \mathrm{de}$ DMSO (dimetilsulfoxido, 100\%), mantendo as placas em agitação por 30 minutos para homogeneizar. A leitura colorimétrica foi feita em espectrofotômetro a $540 \mathrm{~nm}$ (“SpectraMAX 250, Molecular Device, CA, EUA”)

\subsection{OBTENÇÃO DOS NEUTRÓFILOS}

Neutrófilos foram obtidos a partir do sangue retirado com seringa com $100 \mu 1$ de EDTA $(0,5 \mathrm{M}, \mathrm{pH} 8,0)$ da aorta de ratos machos anestesiados por inalação de éter. Os polimorfonucleares foram recuperados por extração de "Percoll": $5 \mathrm{~mL}$ de sangue adicionado a $3 \mathrm{~mL}$ de "Percoll" diluído 56\% em PBS. Após uma centrifugação de 40 minutos (900 xg), a interface contendo os polimorfonucleares foi retirada e os eritrócitos lisados por choque hipotônico através de uma centrifugação (1500 rpm, 
$4^{\circ} \mathrm{C}, 10$ minutos) em solução de lise contendo em g/L: $\mathrm{NH}_{4} \mathrm{Cl}$ 8,3; $\mathrm{NaHCO}_{3}$ 1,0. Este método permite a obtenção de uma solução com aproximadamente $80 \%$ de neutrófilos. As células foram ressuspensas em solução salina "Hanks" balanceada (HBSS, composição em g/L: $\mathrm{NaCl} 8,1 ; \mathrm{KCl} \quad 0,4 \quad \mathrm{KH}_{2} \mathrm{PO}_{4} \quad 0,06 ; \mathrm{CaCl}_{2}$ 0,21; $\mathrm{MgSO}_{4} .7 \mathrm{H}_{2} \mathrm{O}$ 0,24; $\mathrm{NaHCO}_{3}$ 0,25; $\mathrm{Na}_{2} \mathrm{HPO}_{4}$ 0,07; glicose 1,0 ) na concentração de $5.10^{4}$ células $/ \mathrm{mL}$.

\subsection{ENSAIO DE ADESÃO NEUTRÓFILO-ENDOTÉLIO IN VITRO}

Células endoteliais plaqueadas em placas de 96 poços foram mantidas em estufa $\left(37^{\circ} \mathrm{C}, 5 \% \mathrm{CO}_{2}\right)$ até atingir confluência (aproximadamente 5 dias). Antes de iniciar o teste com fármacos as células endoteliais foram lavadas com solução “Hanks". O efeito da melatonina sobre a ativação da interação neutrófilo-endotélio induzida por LPS foi determinado em células incubadas com LPS $(0,1-10 \mu \mathrm{g} / \mathrm{mL})$ por 2 horas, na presença ou ausência de melatonina $(1 \mathrm{nM}$ e $100 \mu \mathrm{M})$. O tratamento agudo de melatonina foi de 2 horas, iniciado junto com LPS, e no tratamento crônico, as células endoteliais foram incubadas com melatonina por 16 dias. Neste caso as células foram replaqueadas em placas de 24 poços contendo ou não melatonina de acordo com cada grupo e o meio foi trocado a cada 48 horas, sempre repondo as soluções. Após os 16 dias, as células foram novamente replaqueadas em placas de 96 poços (para a realização do experimento) por mais 4 dias totalizando 20 dias de incubação. O grupo controle foi obtido icubando-se as células endoteliais pelo mesmo período na presença do veículo dos fármacos em estudo (tampão fosfato contendo 0,5\% de álcool etílico), por $2 \mathrm{~h}$ e/ou 20 dias. Após estes tratamentos, as células foram lavadas novamente com solução de "Hanks" e os neutrófilos adicionados (50 $\mu \mathrm{L}$ contendo $5.10^{4}$ de neutrófilos) foram incubados por 30 minutos. Após este período os neutrófilos não aderidos foram retirados em outra lavagem com solução de "Hanks".

A quantidade de polimorfonucleares aderidos foi avaliada usando ensaio colorimétrico para dosagem da enzima mieloperoxidase, segundo o protocolo: incubação por 5 minutos com tetrametilbenzidina (TMB, $25 \mu \mathrm{L}, 1,6 \mathrm{mM}$ ) seguida de incubação por 2 minutos com $\mathrm{H}_{2} \mathrm{O}_{2}(100 \mu \mathrm{L}, 0,5 \mathrm{mM})$. A velocidade da reação foi 
reduzida pela adição de $\mathrm{H}_{2} \mathrm{SO}_{4}(50 \mu \mathrm{L}, 1 \mathrm{M}$, ) e a absorbância determinada em espectrofotômetro de placa a $450 \mathrm{~nm}$. A quantidade de células aderidas foi determinada utilizando-se uma curva padrão com quantidades conhecidas de neutrófilos (Tamura et al. 2010 - figura 6 reprodução de figura ilustrativa).
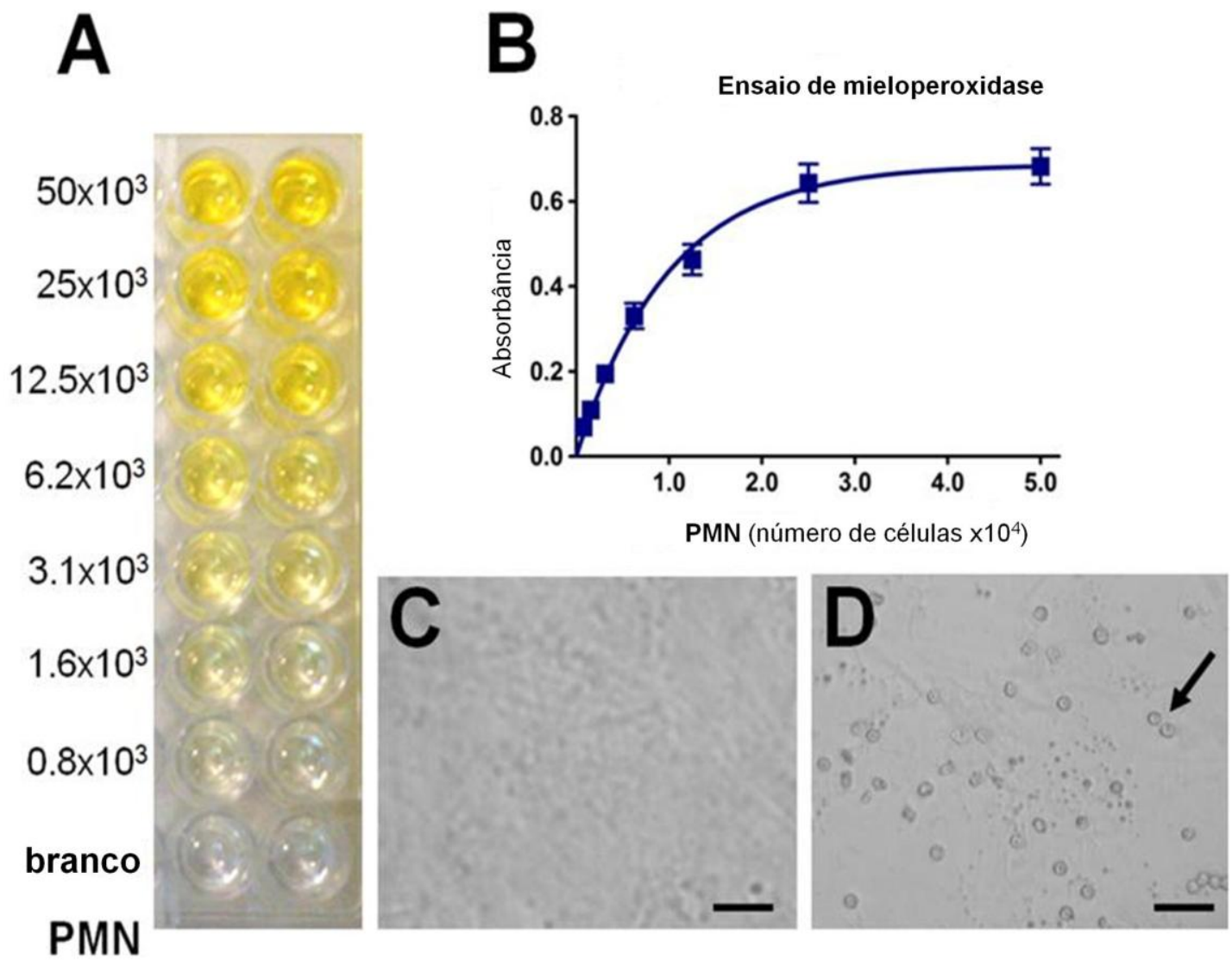

Figura 6: Curva padrão de calibração do ensaio de adesão de neutrófilos em células endoteliais. A - Imagem representativa de doses decrescentes de neutrófilos até o branco (poço sem neutrófilos) para a realização da curva padrão do ensaio de mieloperoxidase. B - Média de curvas padrões obtidas em diferentes dias experimentais. Imagens representativas de $\mathbf{C}$ - células endoteliais em confluência e D - com neutrófilos aderidos às células endoteliais. Seta indica neutrófilo aderido às células endoteliais. Barra de escala $=50 \mu \mathrm{m}$. PMN $=$ polimorfonucleares. Fonte: adaptado de Tamura et al., 2010 .

\subsection{IMUNOCITOQUÍMICA PARA MOLÉCULAS DE ADESÃO (PECAM-1)}

As células endoteliais foram plaqueadas na concentração de $1 \times 10^{4}$ células por poço, em placas próprias para imunocitoquímica e incubadas por 48 horas em estufa a $37^{\circ} \mathrm{C}, 5 \% \mathrm{CO}_{2}$. Após este período as células foram incubadas com LPS $(1 \mu \mathrm{g} / \mathrm{ml}, 2$ 
horas, $37^{\circ} \mathrm{C}, 5 \% \mathrm{CO}_{2}$ ) seguida de incubação com anticorpo para PECAM-1 (anti$\mathrm{CD} 31)$ conjugado à molécula fluorescente $\mathrm{PE}\left(80 \mu \mathrm{l}\right.$, diluição 1:50, 20 minutos, $\left.4^{\circ} \mathrm{C}\right)$. As placas foram lavadas com PBS, seguido de solução fixadora (metanol + acetona 1:1, 15 minutos, $-20^{\circ} \mathrm{C}$ ). As células foram novamente lavadas com PBS (3 vezes) e posteriormente montadas em lâminas com solução glicerol (1:1 diluída em PBS). A análise da imunomarcação foi realizada através de microscopia confocal (LSM 510; Carl Zeiss, Jena, Germany). A marcação foi excitada a $543 \mathrm{~nm}$ e as fluorescências foram emitidas a $560-575 \mathrm{~nm}$.

\subsection{IMUNOCITOQUÍMICA PARA MOLÉCULAS DE ADESÃO (ICAM-1)}

As células endoteliais foram plaqueadas na concentração de $10^{4}$ células por poço, em placas próprias para imunocitoquímica e incubadas por 48 horas em estufa a $37^{\circ} \mathrm{C}, 5 \% \mathrm{CO}_{2}$. Após este período as células foram incubadas com LPS $\left(37^{\circ} \mathrm{C}, 5 \%\right.$ $\mathrm{CO}_{2}$; concentrações e tempo indicados nos gráficos) seguida da incubação com anticorpo para ICAM-1 conjugado ao fluorescente FITC (80 $\mu$ l, diluição 1:75, 20 minutos, $4^{\circ} \mathrm{C}$ ). As placas foram lavadas com PBS, seguido de solução fixadora (metanol + acetona $1: 1,15$ minutos, $\left.-20^{\circ} \mathrm{C}\right)$. As células foram novamente lavadas com PBS (3 vezes) e posteriormente montou-se as lâminas com solução glicerol (1:1 diluída em PBS). A análise da imunomarcação foi realizada através de microscopia confocal (LSM 510; Carl Zeiss, Jena, Germany). A marcação foi excitada a $488 \mathrm{~nm}$ (laser argônio) e as fluorescências foram emitidas a 515-530 nm.

Para a quantificação da expressão de PECAM-1 e ICAM-1, três campos de cada lâmina contendo de 4-8 células foram selecionados aleatoriamente. Após isso, a área de cada célula foi selecionada e a fluorescência emitida foi quantificada utilizando-se o aplicativo ROI do próprio microscópio confocal. 


\subsection{ANÁLISE ESTATÍSTICA}

Os dados estão apresentados como média \pm erro padrão da média (EPM). A comparação das médias entre dois grupos foi feita pelo teste "t de Student" e entre mais que dois grupos foram comparados por análise de variância de amostras independentes seguida do teste de "Newman-Keuls". A probabilidade de 5\% $(\mathrm{p}<0,05)$ foi considerada como diferença significativa entre os grupos. As curvas concentraçãoresposta foram obtidas através de regressão não-linear. Toda a análise estatística foi feita por meio do "software GraphPad Prism ${ }^{\circledR}$ " versão 5.00 (GraphPad Software®). 


\section{RESULTADOS}

\subsection{EFEITO DA MELATONINA NA PROLIFERAÇÃO DE CÉLULAS ENDOTELIAIS}

Com o objetivo de caracterizar que os resultados observados sobre o efeito da melatonina na expressão de proteína em culturas de células endoteliais não fosse consequência de um efeito sobre a proliferação celular, as culturas foram tratadas cronicamente com melatonina $\left(10^{-9} \mathrm{M}\right.$ e $\left.10^{-4} \mathrm{M}\right)$. A avaliação da proliferação celular pelo método de azul de tripan mostrou que apenas após 16 dias melatonina inibiu significantemente $(\mathrm{p}<0,05)$ o crescimento celular (figura 7). Nos demais experimentos apresentados, melatonina foi incubada por apenas duas horas.

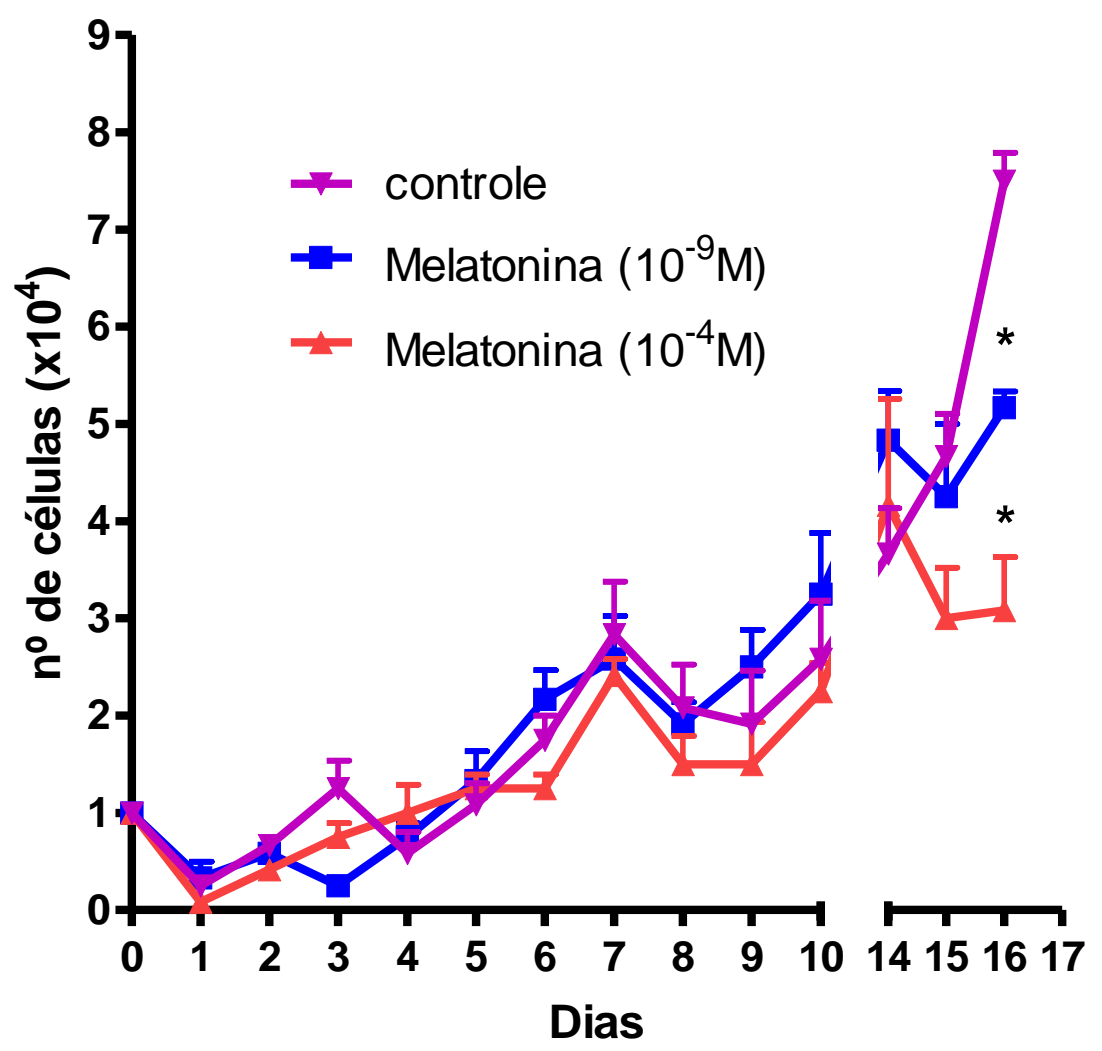

Figura 7: Efeito da melatonina na proliferação de células endoteliais tratadas cronicamente. As células endoteliais foram tratadas com melatonina nas concentrações: $10^{-9} \mathrm{M}$ ou $10^{-4} \mathrm{M}$, ou veículo, por 16 dias consecutivos sendo reposta a cada 48 horas. Valores representados pela média \pm e.p.m. de 3 poços distintos por animal. $\mathrm{N}=3$ animais.

* - significativamente diferente do controle $(\mathrm{p}<0,05)$. 


\subsection{PADRONIZAÇÃO DO ENSAIO DE ADESÃO NEUTRÓFILO-ENDOTÉLIO IN VITRO}

\subsubsection{Determinação da concentração de células endoteliais}

Inicialmente foi realizada a padronização dos ensaios com o intuito de estabelecer condições ideais de cultivo. Para tanto, determinamos a concentração ideal de células endoteliais a serem utilizadas no ensaio para um crescimento mais homogênio das mesmas entre os diferentes grupos. Células endoteliais em diferentes concentrações $\left(10^{3}, 5 \times 10^{3}, 10^{4}, 5 \times 10^{4}\right.$ e $10^{5}$ células/poço) foram plaqueadas e incubadas por 1, 2, 3 e 4 dias, realizando-se o ensaio de MTT.

Os resultados apresentados na figura 8 mostram que diferentes concentrações de células plaqueadas leva a um aumento progressivo do número de células e também altera o tempo para que estas alcancem a confluência. As concentrações de $10^{4}, 5 \times 10^{4}$ e10 5 atingiram a comfluência no quarto dia de cultivo, provavelmente a concentração de $10^{5}$ tenha atingido essa confluência no terceiro dia. Em experimentos anteriores realizados por nosso grupo havia sido verificado que quando as células eram plaqueadas na concentração de $10^{4}$ células/poço a confluência era atingida entre cinco ou seis dias de cultura (comunicação pessoal Eduardo Koji Tamura). Portanto, nas outras concentrações utilizadas as células demorariam mais que quatro dias para atingirem a confluência.

Podemos observar no gráfico que as concentrações experimentais ideais seriam as de $10^{4}$ e $5 \times 10^{4}$ células/poço por apresentarem um crescimento homogênio, sem muita morte celular inicial. Portanto utilizamos a concentração de $10^{4}$ células/poço nos experimentos seguintes. 


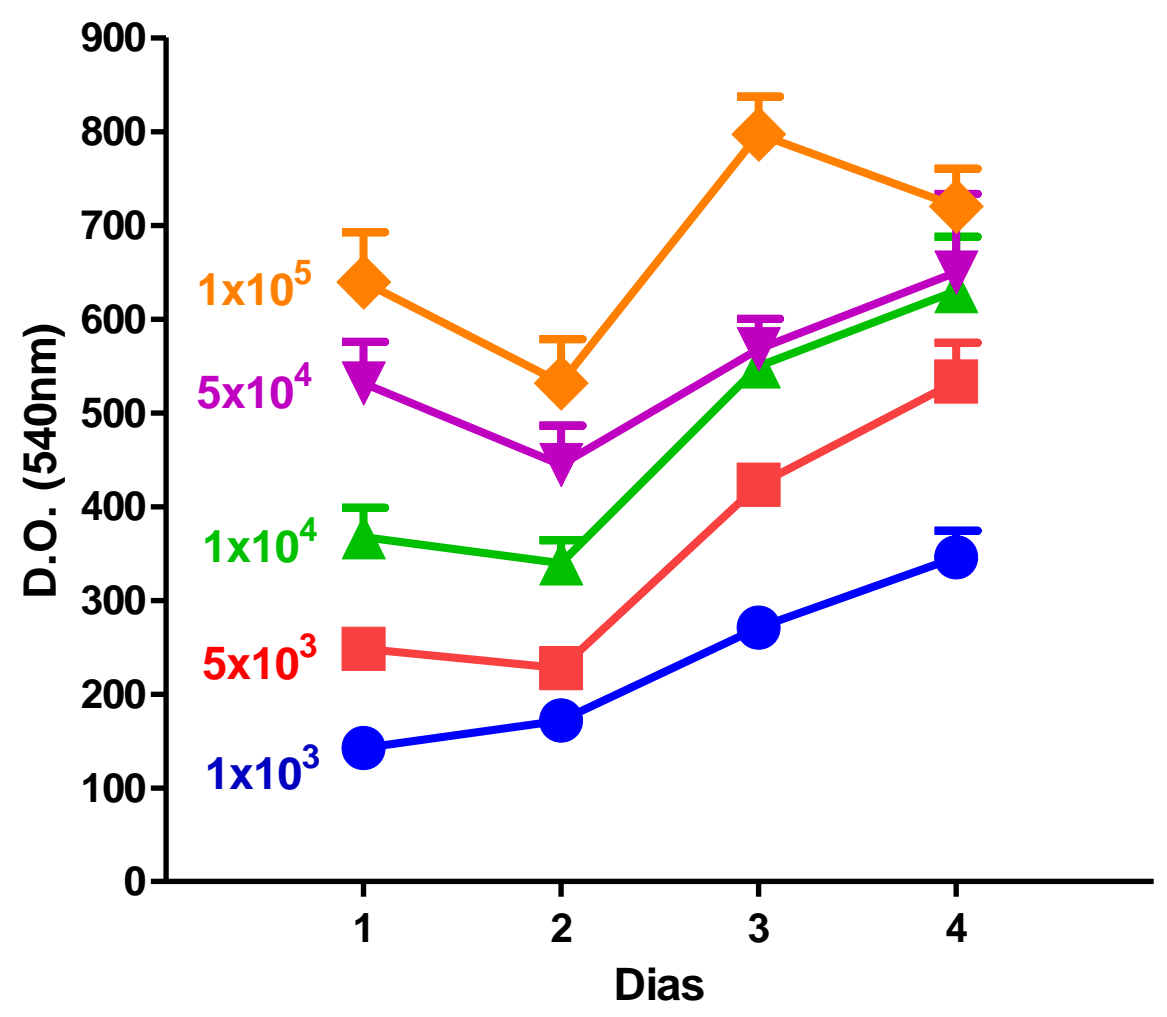

Figura 8: Relação do crescimento celular ao longo do tempo. Células endoteliais em diferentes concentrações $\left(10^{3}, 5 \times 10^{3}, 10^{4}, 5 \times 10^{4}\right.$ e $10^{5}$ células/poço) foram plaqueadas em três placas de 96 poços (cada placa continha células de ratos diferentes) e incubadas de 1-4 dias seguindo os procedimentos normais para manter a cultura (trocando-se o meio a cada 48 horas). $\mathrm{O}$ ensaio de MTT foi realizado a cada dia durante 4 dias.

\subsubsection{Determinação da concentração de neutrófilos}

Em placas contendo células endoteliais foram adicionadas quantidades crescentes de neutrófilos (800 a 50.000) e observada a sua aderência. O número de neutrófilos aderidos às células endoteliais aumentou de maneira dependente da quantidade de neutrófilos adicionados a elas (figura 9). A adesão foi calculada usando-se uma curva padrão de calibração em poços contendo quantidades conhecidas de neutrófilos. Nos experimentos subsequentes foi utilizado um total de $5 \times 10^{4}$ neutrófilos, visto que foi observada uma boa distinção entre a reação corada na ausência e presença de neutrófilos. 


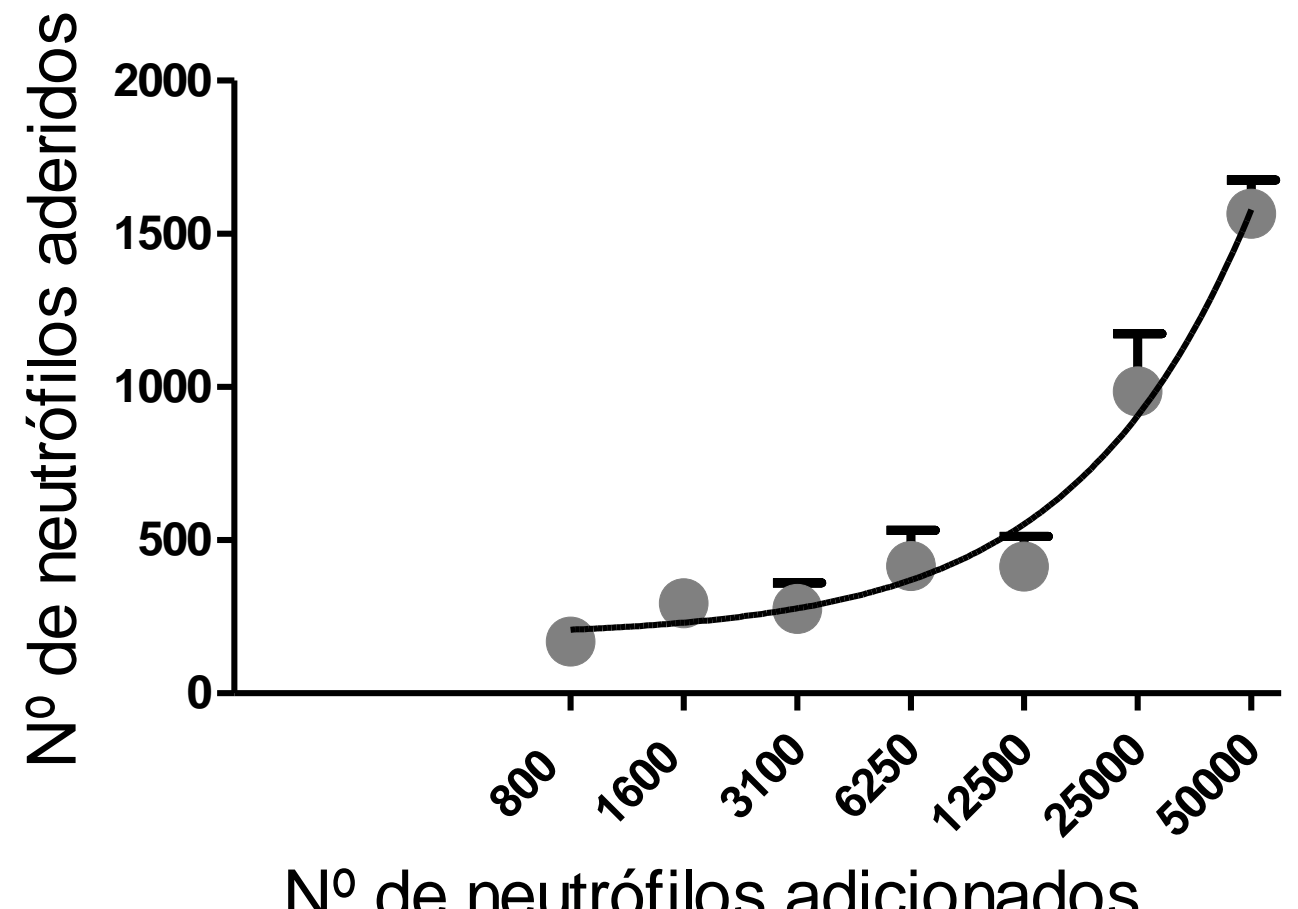

Figura 9: Relação entre quantidade de neutrófilos adicionados e aderidos em placas contendo células endoteliais. Este ensaio foi repetido com culturas de células endoteliais obtidas de dois ratos, processadas em períodos diferentes. Cada ponto representa valores medidos em 8 a 16 poços diferentes. Valores apresentados por média \pm e.p.m. A curva foi traçada de acordo com um ajuste não linear.

\subsubsection{Efeito do LPS na adesão de neutrófilos}

Estes experimentos foram realizados dois protocolos: um incubando somente as células endoteliais, e outro incubando tanto as células endoteliais quanto os neutrófilos com LPS. Para o primeiro protocolo, as células endoteliais foram incubadas com LPS por duas horas, seguida de lavagem com "Hanks" e incubação com os neutrófilos por mais 30 minutos na ausência de LPS. No outro protocolo, houve uma incubação prévia das células endoteliais (2 horas) e dos neutrófilos (5 minutos) com LPS seguida de co-incubação dos dois tipos celulares ainda na presença de LPS por mais 30 minutos. Em ambos os protocolos LPS induziu um aumento da adesão de neutrófilos à cultura de células endoteliais dependente da concentração 
(figura 10). O máximo de resposta em ambos os protocolos foi observado com a concentração de $1,0 \mu \mathrm{g} / \mathrm{mL}$ de LPS.

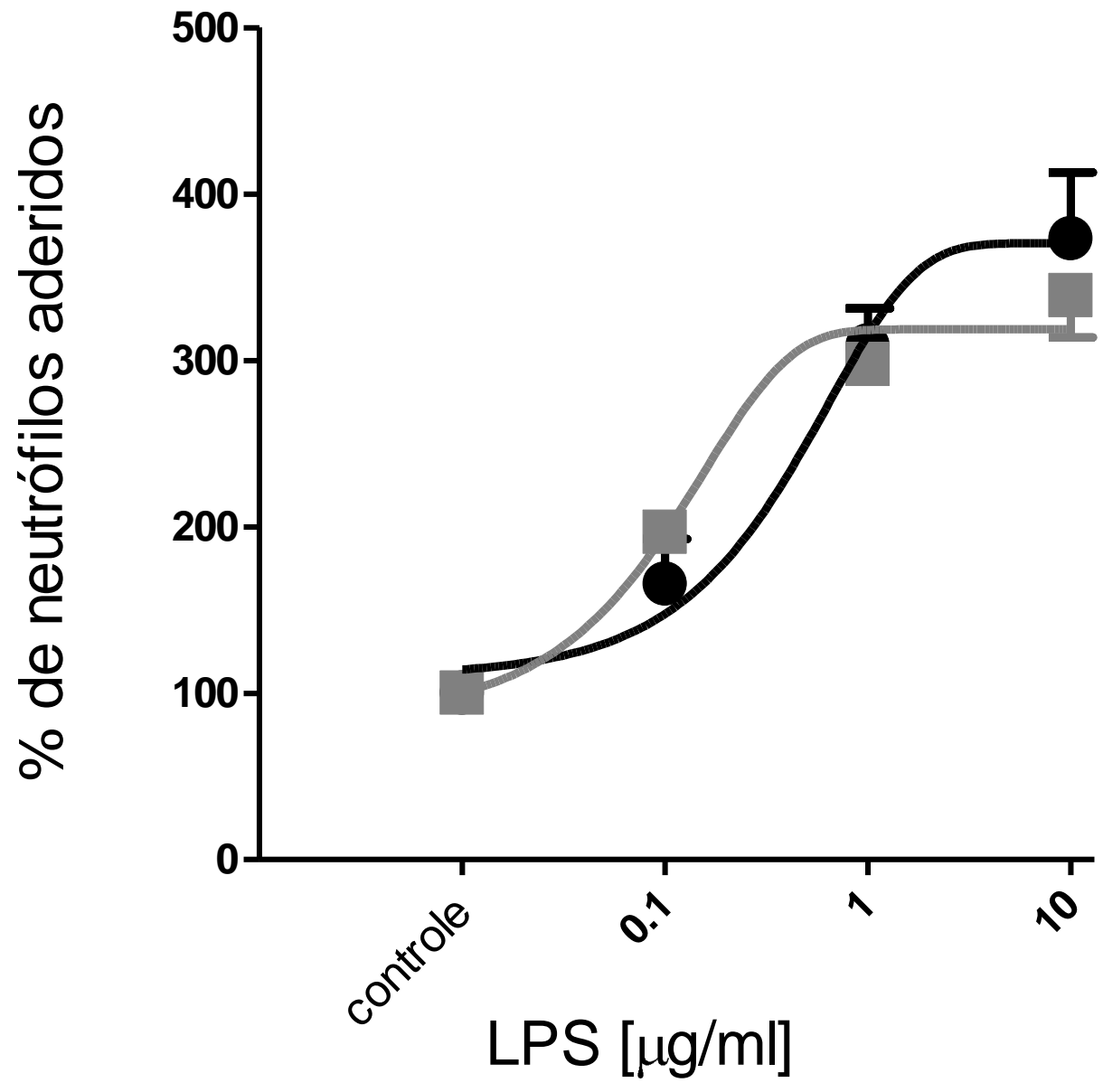

Figura 10: Curva concentração-resposta de LPS sobre a adesão de células endoteliais. As células endoteliais foram estimuladas com LPS nas concentrações 0,$1 ; 1,0$ e $10 \mu \mathrm{g} / \mathrm{ml}$ por duas horas. Em cinza (quadrado), somente as células endoteliais foram incubadas com LPS (2 horas). Em preto (círculo), tanto as células endoteliais (2 horas) como os neutrófilos (5 minutos) foram incubados com LPS. Após o período de incubação os neutrófilos foram adicionados às células endoteliais para aderirem por 30 minutos. Dados apresentados como média \pm e.p.m. medidos de 8 poços distintos de 3 culturas diferentes. A curva foi traçada de acordo com um ajuste não linear seguindo uma equação sigmóide.

\subsubsection{Efeito do LPS na expressão de PECAM-1}

PECAM-1 é uma molécula de adesão expressa constitutivamente em células endoteliais servindo como um de seus marcadores (Dong et al., 1997). O ensaio de 
imunocitoquímica foi realizado com células endoteliais $\left(10^{4}\right.$ células no início do experimento) cultivadas por 48 horas e incubadas com LPS por 2 horas nas concentrações 0,$1 ; 1,0$ e $10 \mu \mathrm{g} / \mathrm{ml}$. A análise da expressão de PECAM-1 foi realizada por microscopia confocal. O efeito máximo de expressão dessas moléculas foi observado com a concentração de LPS $1,0 \mu \mathrm{g} / \mathrm{ml}$ e a resposta foi mantida com a máxima concentração utilizada de $10 \mu \mathrm{g} / \mathrm{ml}$ (figura 11).

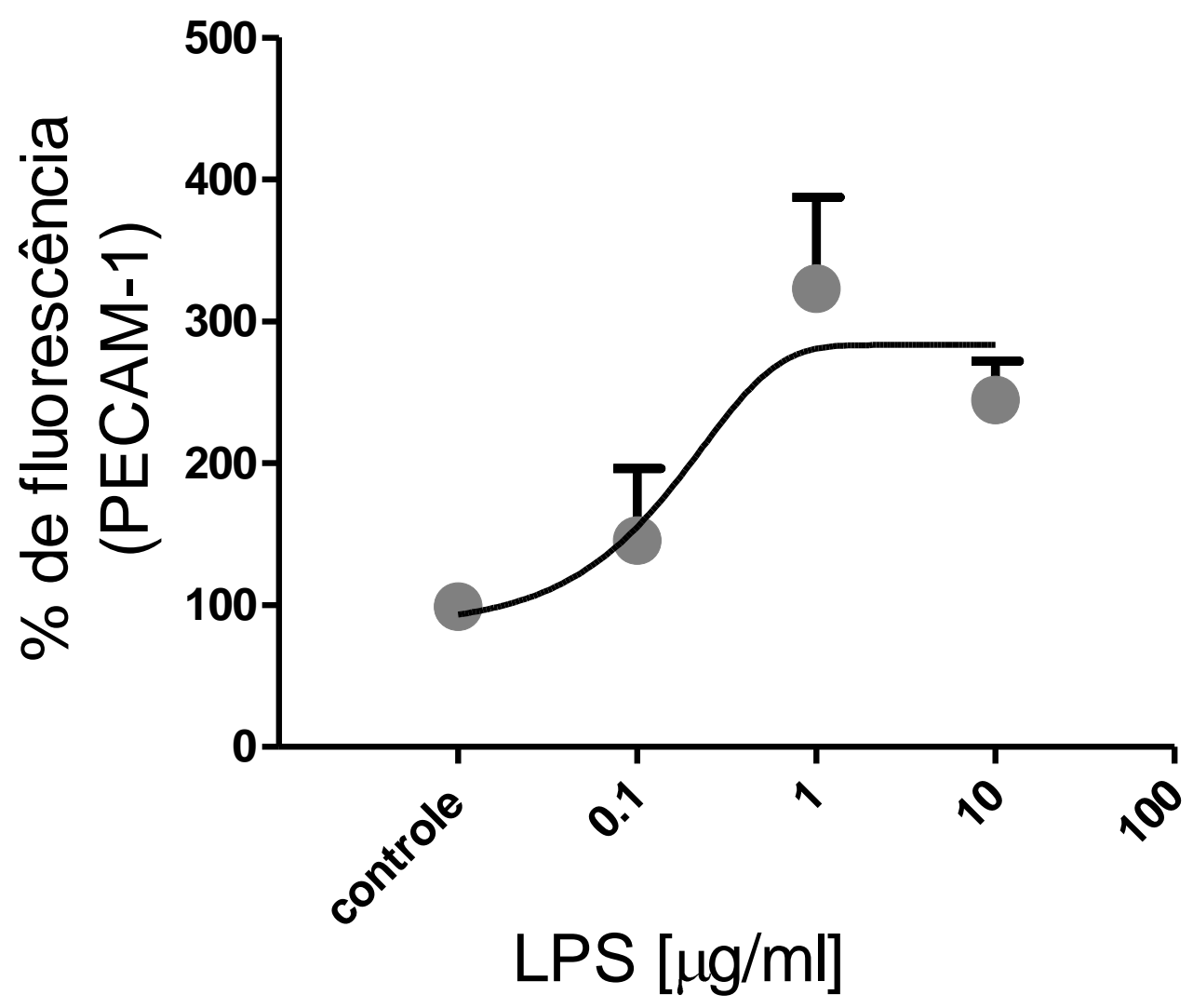

Figura 11: Curva dose-resposta de LPS sobre a expressão de moléculas de adesão PECAM-1. As células endoteliais cultivadas em placas para imunocitoquímica foram estimuladas com LPS nas concentrações 0,$1 ; 1,0$ e $10 \mu \mathrm{g} / \mathrm{ml}$ por 2 horas. Após este período as células foram incubadas com anticorpo para PECAM-1 (diluição 1:75) conjugado à molécula fluorescente PE, por 20 minutos a $4^{\circ}$ C. As células foram fixadas e a quantificação foi feita por microscopia confocal, medida em 5 a 10 células distintas, para cada grupo de 3 culturas diferentes Os dados estão expressos como média \pm e.p.m e foram ajustados por regressão não linear. 


\subsubsection{Efeito do LPS na expressão de ICAM-1}

As células endoteliais $\left(10^{4}\right.$ células/poço) foram cultivadas por 48 horas em placas próprias para imunocitoquímica. Após esse período foram incubadas com LPS na concentração $1,0 \mu \mathrm{g} / \mathrm{ml}$ nos diferentes tempos (30 minutos, 1 e 2 horas) e a leitura feita em microscopia confocal. O gráfico abaixo (figura 12) mostra que, com 30 minutos, o aumento da expressão de ICAM-1 é máximo entrando em um platô nos dois tempos seguintes.

Considerando que 2 horas de LPS foi suficiente para aumentar a expressão de ICAM-1, PECAM-1 e adesão de neutrófilos, passamos a usar este tempo para analisar o efeito da melatonina.

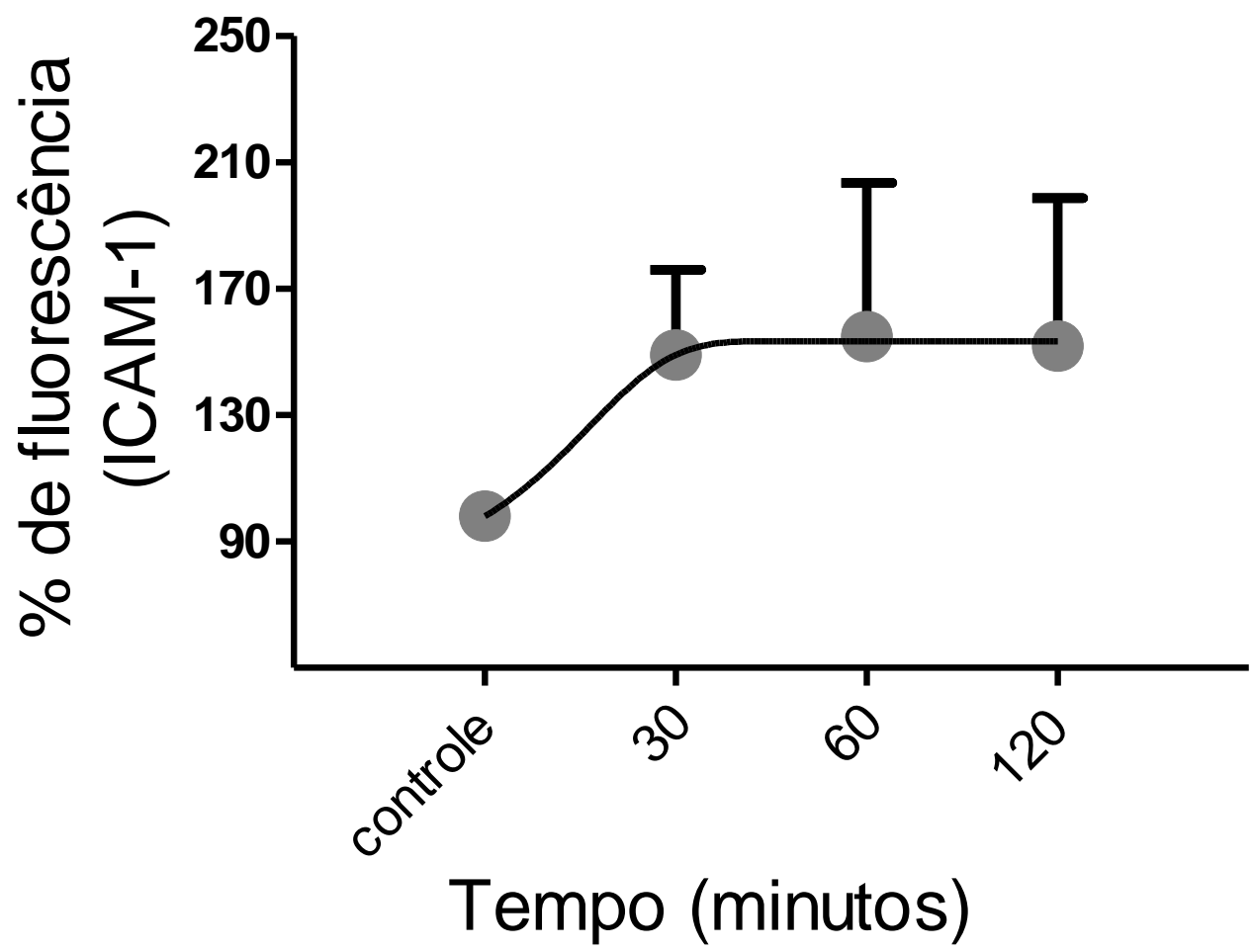

Figura 12: Curva de tempo da expressão de moléculas de adesão ICAM induzida por LPS. As células endoteliais cultivadas em placas para imunocitoquímica foram estimuladas com LPS $1 \mu \mathrm{g} / \mathrm{ml}$, por 30 minutos, 1 e 2 horas. Após estes períodos as células foram incubadas com anticorpo para ICAM-1 (diluição 1:50) conjugado à molécula fluorescente FITC por 20 minutos a $4^{\circ} \mathrm{C}$. As células foram fixadas e a quantificação foi feita por microscopia confocal, medida em 7 a 10 células distintas, para cada grupo de 3 culturas diferentes. Os dados estão expressos como média \pm e.p.m e foram ajustados por regressão não-linear. 


\subsection{EFEITOS DA MELATONINA}

\subsubsection{Adesão de neutrófilos}

O estímulo de células endoteliais com LPS $1,0 \mu \mathrm{g} / \mathrm{ml}$ por 2 horas aumentou significativamente a capacidade de aderir neutrófilos quer em células endoteliais incubadas apenas com meio de cultura quer nas incubadas com melatonina por 20 dias (tratamento crônico, trocando-se o meio com melatonina a cada 48 horas) (figura 13). A incubação das células endoteliais por apenas duas horas com melatonina $\left(10^{-9}\right.$ $\mathrm{M}$ ou $10^{-4} \mathrm{M}$ ) inibiu o efeito do LPS (figuras 13 e 14). Portanto, melatonina incubada de forma aguda é capaz de inibir o efeito estimulante de LPS. Além disso, a incubação com melatonina por longos prazos não leva a processos de dessensibilização. Considerando que a melatonina poderia estar sendo metabolizada in vitro já que a troca de meio era feita a cada 48 horas, podemos concluir que o efeito da melatonina sobre o aumento da adesão de neutrófilos em células endoteliais, nessas condições, pode ser reversível. 


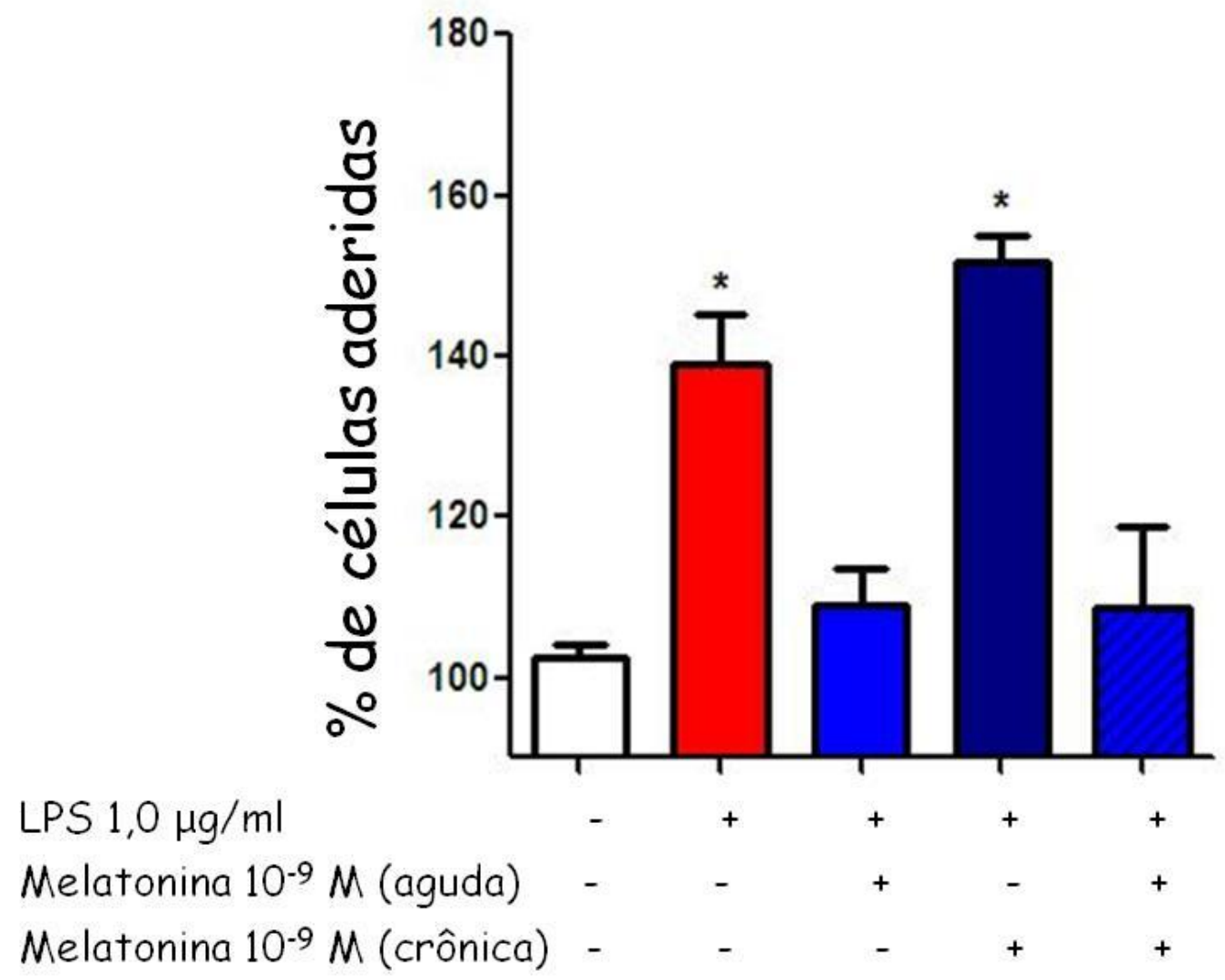

Figura 13: Efeito do tratamento agudo ( 2 horas) e crônico (20 dias) da melatonina sobre a adesão de neutrófilos em células endoteliais in vitro. Células endoteliais tratadas ou não com LPS $1 \mu \mathrm{g} / \mathrm{ml}$ (2 horas) foram incubadas simultaneamente, ou por 20 dias com melatonina $10^{-9} \mathrm{M}$. Durante o tratamento crônico, o meio contendo melatonina foi trocado a cada 48 horas. Após os períodos de incubação, neutrófilos $\left(5 \times 10^{4}\right)$ foram adicionados para aderirem por 30 minutos. A quantidade de neutrófilos aderidos foi medida através de reação de mieloperoxidase. Os valores são expressos como porcentagem de células aderidas considerando como normalizador o grupo não tratado (100\%). Os dados demonstram média \pm e.p.m da porcentagem de células aderidas obtidas em 4 culturas diferentes. Para cada cultura foram plaqueados 4 a 8 poços na mesma condição experimental.

* - significativamente iguais entre si e significativamente diferentes de todos os outros grupos $(\mathrm{P}<0,05)$. 


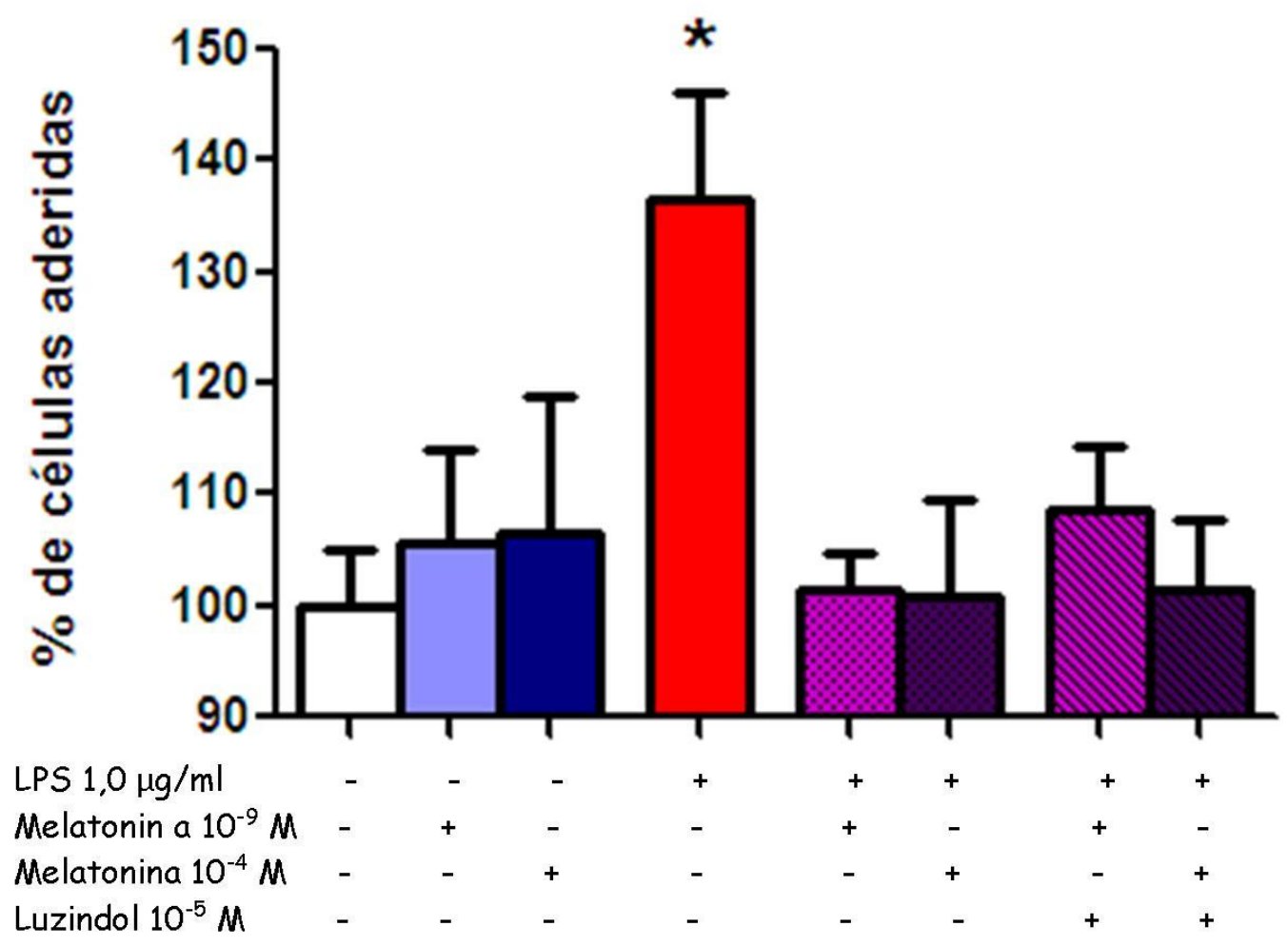

Figura 14: Efeito da melatonina e do antagonista luzindol sobre a adesão de neutrófilos. Células endoteliais foram incubadas por 2 horas com LPS $1,0 \mu \mathrm{g} / \mathrm{ml}$ na presença ou ausência de melatonina $\left(10^{-9} \mathrm{M} \mathrm{e} 10^{-4} \mathrm{M}\right)$, sendo alguns grupos pré-incubados por 1 hora com o antagonista competitivo de melatonina, luzindol $\left(10^{-5} \mathrm{M}\right)$. A seguir foram adicionados $5 \times 10^{4}$ neutrófilos. A quantidade de neutrófilos aderidos após 30 minutos de sua adição foi medida através de reação de mieloperoxidase. Os valores são expressos como porcentagem de células aderidas considerando como normalizador o grupo não tratado $(100 \%)$. Os dados demonstram média \pm e.p.m da porcentagem de células aderidas obtidas em 4 culturas diferentes. Para cada cultura foram plaqueados 4 a 8 poços na mesma condição experimental.

* - significativamente diferente de todos os outros grupos $(\mathrm{P}<0,05)$.

\subsubsection{Expressão de moléculas de adesão PECAM-1 e ICAM-1}

Células endoteliais $\left(10^{4}\right)$ foram cultivadas por $48 \mathrm{~h}$ em placas próprias. As células foram incubadas com LPS (2h) nas concentrações 0,$1 ; 1,0$ e $10 \mu \mathrm{g} / \mathrm{ml}$ e melatonina $10^{-9}$ e $10^{-4} \mathrm{M}(2 \mathrm{~h})$. A análise da expressão de moléculas de adesão PECAM-1 e ICAM-1 foi realizada através de ensaios de imunocitoquímica, e a leitura feita em microscopia confocal. 
Nas figuras 15 e 16 são apresentadas imagens representativas da expressão de PECAM-1 e ICAM-1, respectivamente, para a incubação com LPS seguido de tratamento com a menor concentração de melatonina.

Os resultados mostram que melatonina inibe o aumento da expressão de moléculas de adesão (PECAM-1 e ICAM-1) em células endoteliais em cultura induzido por LPS e este efeito ocorre tanto em concentrações baixas $\left(10^{-9} \mathrm{M}\right)$ quanto em concentrações mais altas de melatonina $\left(10^{-4} \mathrm{M}\right)$ (figuras 17 e 18 ).

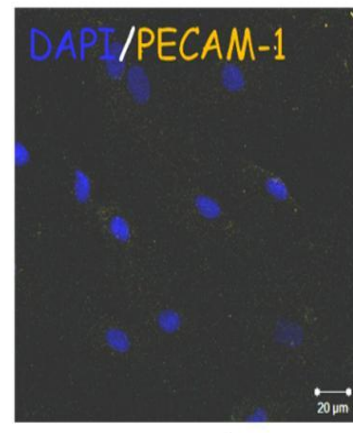

controle

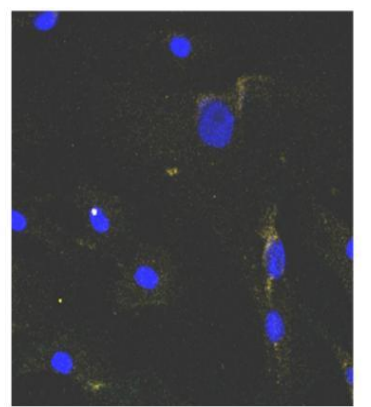

LPS $0,1 \mu \mathrm{g} / \mathrm{ml}$

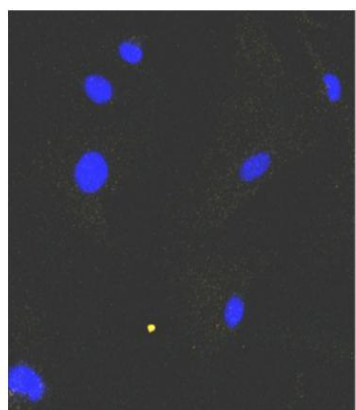

LPS $0,1 \mu \mathrm{g} / \mathrm{ml}+$

Melatonina $10^{-9} \mathrm{M}$

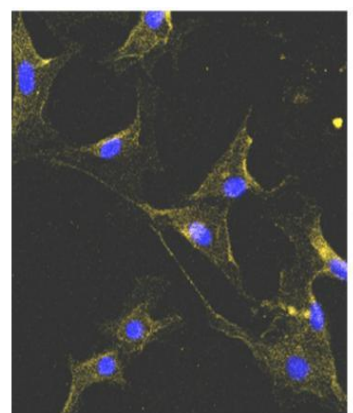

LPS $1,0 \mu \mathrm{g} / \mathrm{ml}$

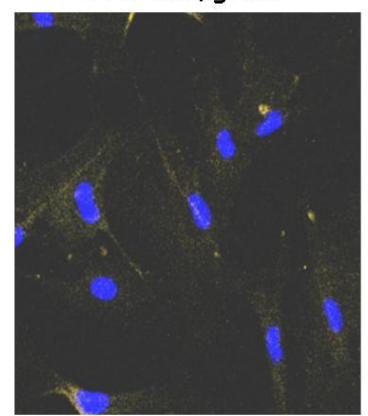

LPS $1,0 \mu \mathrm{g} / \mathrm{ml}+$

Melatonina $10^{-9} \mathrm{M}$

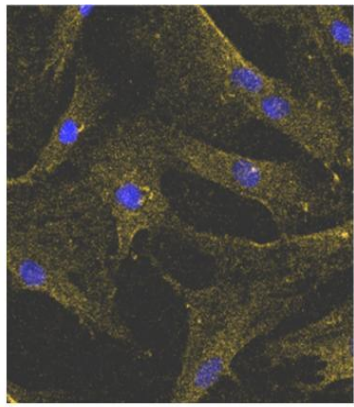

LPS $10,0 \mu \mathrm{g} / \mathrm{ml}$

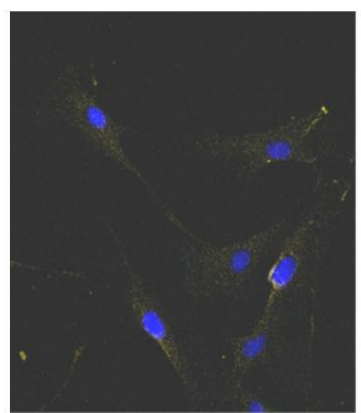

LPS $10,0 \mu \mathrm{g} / \mathrm{ml}+$

Melatonina $10^{-9} \mathrm{M}$

Figura 15: Imagem representativa do efeito da melatonina sobre a expressão de PECAM-1 induzida por LPS. As células endoteliais $\left(1 \times 10^{4}\right)$ foram cultivadas por 48 horas em placas próprias para imunocitoquímica. Após esse período as células foram incubadas com LPS ( 2 horas) nas concentrações 0,$1 ; 1$ e $10 \mu \mathrm{g} / \mathrm{ml}$ e melatonina $10^{-9} \mathrm{M}$ (2 horas). A leitura foi feita em microscopia confocal. Em azul, 4,6-diamidino 2-fenilindol, diidrocloreto (DAPI), marcador nuclear. Em amarelo, moléculas de adesão PECAM-1. 


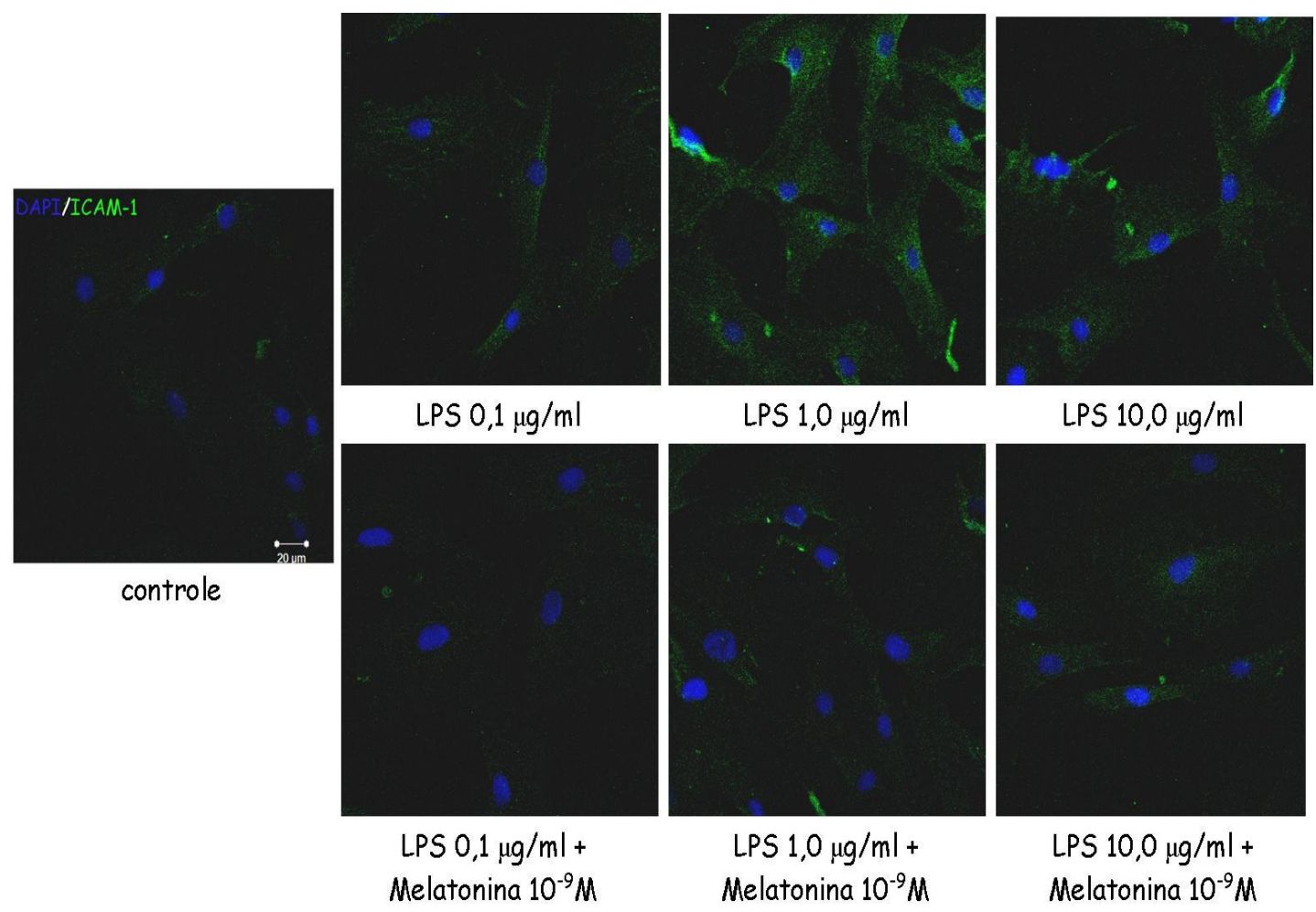

Figura 16: Imagem representativa do efeito da melatonina sobre a expressão de ICAM-1 induzida por LPS. As células endoteliais $\left(1 \times 10^{4}\right)$ foram cultivadas por 48 horas em placas próprias para imunocitoquímica. Após esse período as células foram incubadas com LPS (2 horas) nas concentrações 0,$1 ; 1$ e $10 \mu \mathrm{g} / \mathrm{ml}$ e melatonina $10^{-9} \mathrm{M}$ (2 horas). A leitura foi feita em microscopia confocal. Em azul, 4,6-diamidino 2-fenilindol, diidrocloreto (DAPI), marcador nuclear. Em verde, moléculas de adesão ICAM-1.

Avaliamos então se o efeito da melatonina em inibir a expressão de moléculas de adesão era devido à ativação de seus receptores de membrana $\left(\mathrm{MT}_{1}, \mathrm{MT}_{2}\right.$ e $\left.M T_{3}\right)$. Para isso, usamos o luzindol, um bloqueador não seletivo dos receptores de membrana de melatonina (figuras 17 e 18).

As células endoteliais $\left(10^{4}\right.$ células/poço) foram cultivadas por 48 horas em placas próprias para imunocitoquímica. As células foram pré-incubadas com luzindol $10^{-5} \mathrm{M}$ (concentração capaz de inibir todos os receptores de membrana de melatonina) por 1 hora e posteriormente foi adicionado LPS $(1 \mu \mathrm{g} / \mathrm{ml})$ e/ou melatonina $10^{-9} \mathrm{M} \mathrm{e}$ $10^{-4} \mathrm{M}$ por 2 horas. A leitura foi feita em microscopia confocal.

Os dados mostram que tanto para inibir a expressão de PECAM-1 quanto ICAM-1 a melatonina não atua via receptores de membrana, pois o bloqueio dos mesmos com luzindol não foi capaz de reverter a ação da melatonina. 


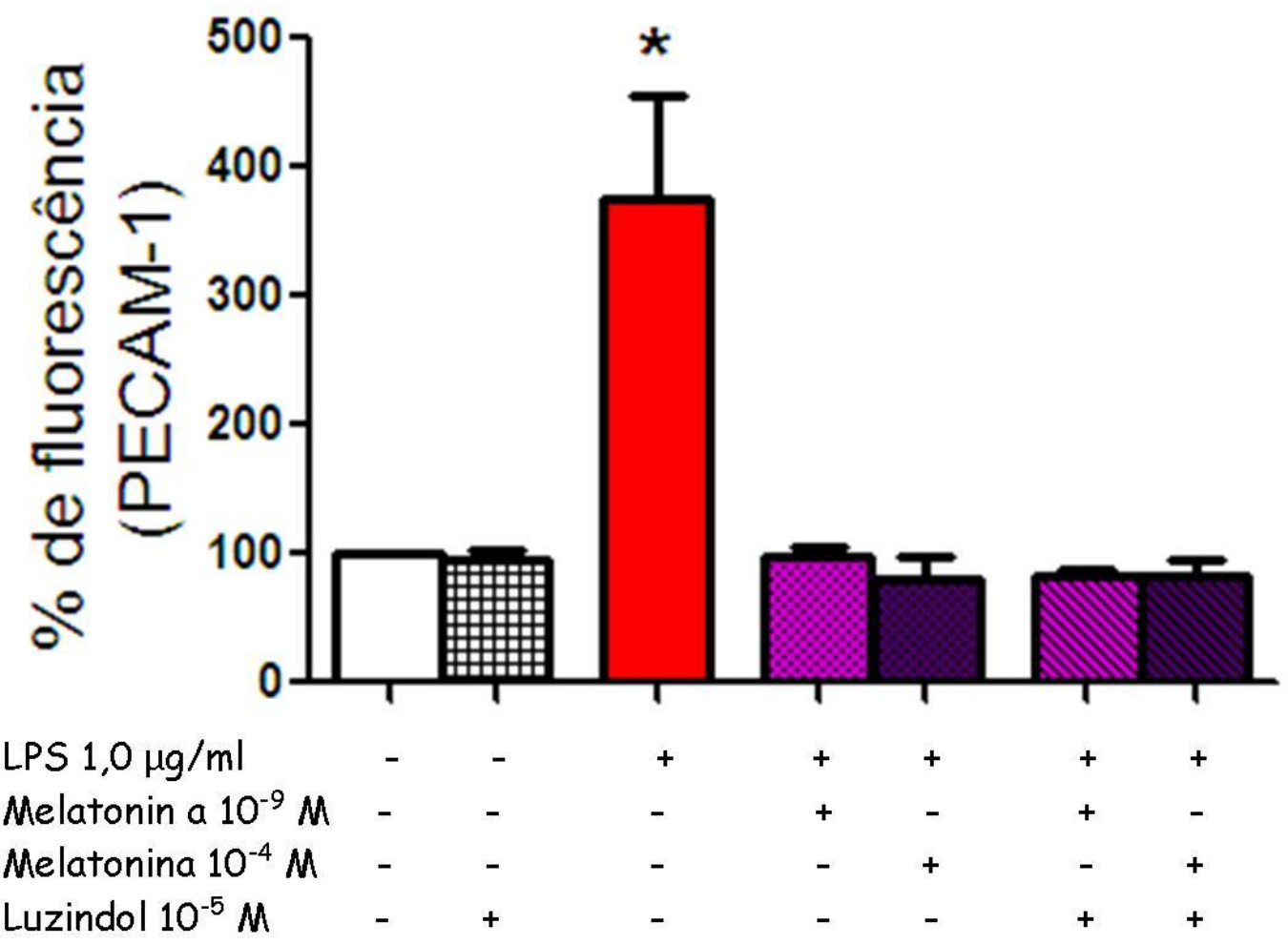

Figura 17: Efeito da melatonina e de luzindol sobre a expressão de PECAM-1 induzida por LPS. As células endoteliais $\left(10^{4}\right.$ células/poço) foram cultivadas por 48 horas em placas próprias para imunocitoquímica. As células endoteliais foram incubadas com LPS $(1,0 \mu \mathrm{g} / \mathrm{ml})$ na presença de melatonina $\left(10^{-9} \mathrm{M}\right.$ ou $\left.10^{-4} \mathrm{M}\right)$ ou veículo. $\mathrm{O}$ antagonista de receptores de melatonina, luzindol $\left(10^{-5}\right.$ M), foi pré-incubado por 1 hora. A leitura foi feita em microscopia confocal. Os dados demonstram média \pm e.p.m da porcentagem de expressão de PECAM-1 obtidas em 4 culturas diferentes. Para cada cultura foram plaqueados 4 a 8 poços na mesma condição experimental.

* - significativamente diferente de todos os outros grupos $(\mathrm{P}<0,05)$. 


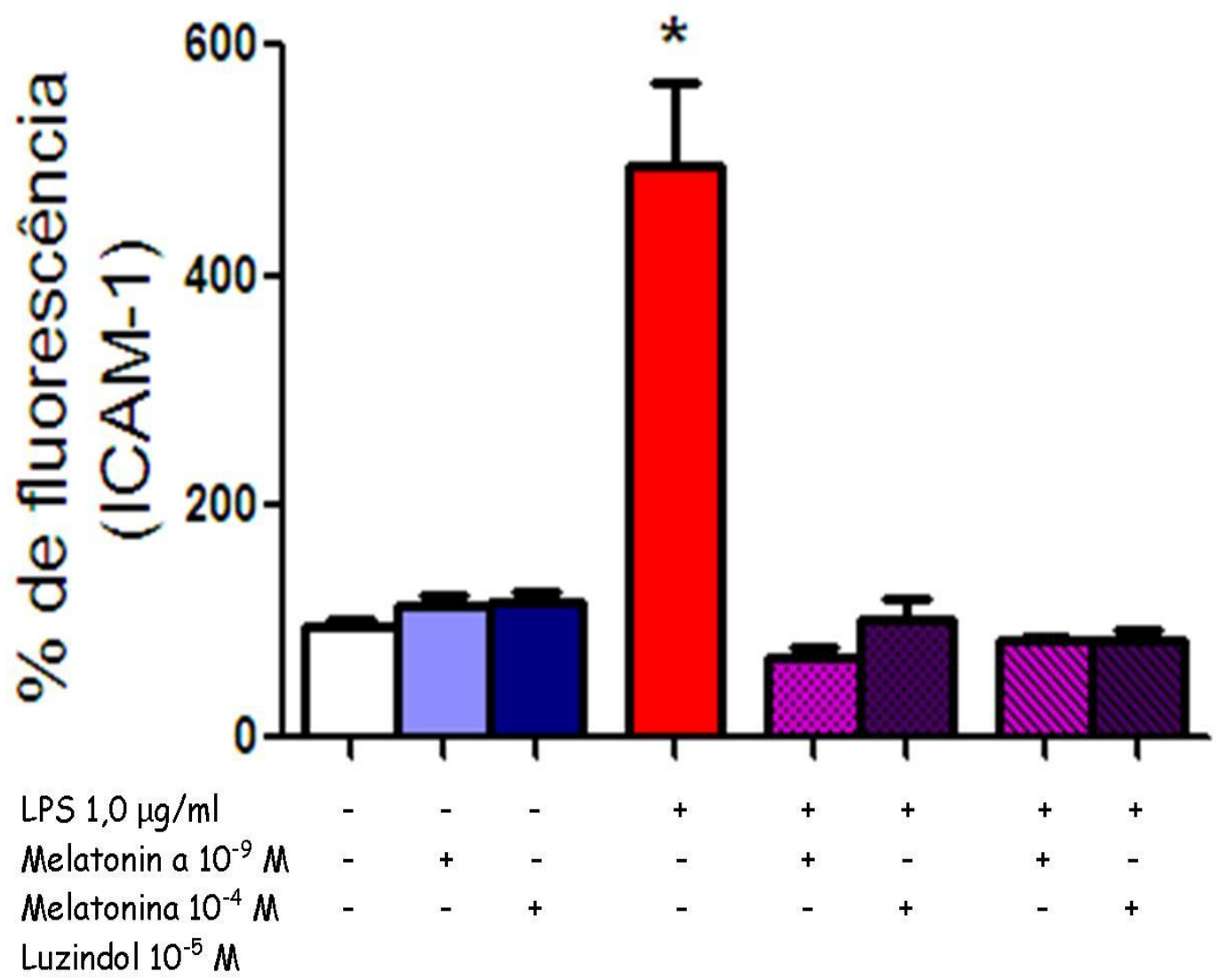

Figura 18: Efeito da melatonina e de luzindol sobre a expressão de ICAM-1 induzida por LPS. As células endoteliais $\left(10^{4}\right.$ células/poço) foram cultivadas por 48 horas em placas próprias para imunocitoquímica. As células endoteliais foram incubadas com LPS $(1,0 \mu \mathrm{g} / \mathrm{ml})$ na presença de melatonina $\left(10^{-9} \mathrm{M}\right.$ ou $\left.10^{-4} \mathrm{M}\right)$ ou veículo. $\mathrm{O}$ antagonista de receptores de melatonina, luzindol $\left(10^{-5} \mathrm{M}\right)$, foi préincubado por 1 hora. A leitura foi feita em microscopia confocal. Os dados demonstram média \pm e.p.m da porcentagem de expressão de ICAM-1 obtida em 4 culturas diferentes. Para cada cultura foram plaqueados 4 a 8 poços na mesma condição experimental.

*- significativamente diferente de todos os outros grupos $(\mathrm{P}<0,05)$ 


\section{DISCUSSÃO}

Células endoteliais em cultura têm sido importante fonte de informação sobre a interação entre substâncias presentes na corrente sanguínea e a reatividade ou permeabilidade vascular. Apesar da retirada das células de seu meio natural, o uso de células isoladas permite avaliar as mesmas como alvos diretos de substâncias circulantes. A retirada das células para cultura pode causar a perda de algumas de suas funções, criando uma situação artificial, podendo tornar os resultados contraditórios aos encontrados in vivo. No intuito de manter a integridade das células, as culturas foram feitas de acordo com protocolo elaborado inicialmente por Chen e colaboradores (1995), o qual não utiliza nenhuma substância proteolítica que possa prejudicar a membrana das células cultivadas, esperando que elas migrem por conta própria do tecido para a placa de cultura. Assim, evitamos a perda de suas funções normais.

O ensaio funcional utilizado neste trabalho avaliou o número de neutrófilos aderidos às células endoteliais cultivadas, revelado a partir de uma reação colorimétrica da enzima mieloperoxidase. Esta é uma enzima presente apenas nos neutrófilos e não nas células endoteliais. Em vista da variabilidade observada neste ensaio, fez parte desta dissertação de mestrado caracterizar condições controladas para o uso das células endoteliais em cultura. Inicialmente foi avaliado se a melatonina alteraria a cultura celular utilizada em nossos experimentos, visto que em outros modelos celulares a melatonina tem efeito antiproliferativo, como de células provenientes de tumores de mama sensíveis a estrógenos e de células de melanoma $S$ 91 (Kiefer et al., 2002; Kadekaro et al., 2004). Interessante notar que em ambos os tipos celulares a superexpressão de receptores para melatonina $\mathrm{MT}_{1}$ aumentava o efeito antiproliferativo da melatonina.

Ao avaliar as curvas de crescimento de células endoteliais, caracterizadas a partir da expressão de PECAM-1 (Dong et al., 1997), na presença de melatonina (10

${ }^{-9}$ e $10^{-4} \mathrm{M}$ ) verificamos que esta indolamina só é capaz de inibir significativamente o crescimento de células endoteliais após 16 dias de cultivo (reveja na figura 7). Portanto, da mesma forma como observado em algumas células tumorais (Martín et al.,2006; Moretti et al., 2000) e células endoteliais derivadas de cordão umbilical 
humano (Cui et al., 2006), as células endoteliais derivadas de músculo cremaster de rato não tem seu número alterado por incubação de duas horas com melatonina. Este efeito antiproliferativo in vitro da melatonina pode ser alvo para diversos estudos com o intuito de entender melhor este mecanismo para futuros estudos contra o câncer, pois sabemos que o crescimento do câncer se dá devido a vasta irrigação das células cancerosas pela formação de novos vasos sanguíneos ao redor das mesmas (Gardlik et al., 2011). Caso a melatonina seja capaz de inibir o crescimento desses novos vasos, as células cancerígenas não terão mais fonte de alimentação, podendo causar a inibição de seu crescimento e/ou sua morte.

Ainda com o intuito de estabelecer condições ideais de cultivo determinamos a concentração ideal de células endoteliais a serem utilizadas no ensaio para um crescimento mais homogêneo das mesmas. Entre os cuidados com este tipo de cultura celular, também é importante salientar a hora de morte dos animais doadores, visto que a atividade das células endoteliais em cultura varia de acordo com as condições do animal doador (Marçola, 2011). Os experimentos apresentados neste trabalho foram todos realizados com animais sacrificados entre $11 \mathrm{~h} 00$ e $13 \mathrm{~h} 00$. Os resultados mostraram que dependendo da concentração de células endoteliais colocadas na placa de cultura o tempo para que estas alcancem a confluência se altera. As concentrações $10^{4} .5 \times 10^{4}$ células/poço atingiram a confluência no quarto dia de cultivo. Escolhemos a concentração menor de células endoteliais para todos os nossos experimentos.

Tendo estabelecido essas condições de cultivo, passamos a analizar o efeito do LPS sobre a interação neutrófilo-endotélio. Dados da literatura mostram que o LPS é capaz de aumentar a adesão de neutrófilos e a expressão de moléculas de adesão em células endoteliais se injetado localmente no animal (Andonegui et al., 2002). Nestes casos, não sabemos se o efeito observado é devido a uma ativação apenas das células endoteliais ou se ao injetar a substância no animal ocorre toda uma reação melhor fundamentada espaço e temporalmente. Para entendermos esse efeito, foram realizados dois protocolos: 1) incubando-se apenas as células endoteliais com LPS antes da exposição aos neutrófilos; 2) incubando-se ambas as células, endoteliais e neutrófilos, simultaneamente com LPS. Nossos dados mostraram que não houve diferença entre os dois protocolos. Portanto, nos demais experimentos optamos por realizar o pré-tratamento somente das células endoteliais. Em resumo, o tratamento de 
células endoteliais em cultura com LPS aumenta a capacidade de adesão de neutrófilos.

Nossos experimentos com expressão de moléculas de adesão (PECAM-1 e ICAM-1) mostram que LPS induz a expressão de ambas as moléculas. Todas estas proteínas sabidamente fazem parte do conjunto de moléculas responsáveis pela montagem da resposta inflamatória, cujos genes podem ser ativados por LPS via interação com receptores TLR4 e a translocação nuclear do fator de transcrição NFKB (Hebeda et al., 2011; Kim et al., 2011). De acordo com o observado para a expressão de iNOS (Tamura et al., 2009), a máxima adesão de neutrófilos e expressão de PECAM-1 foi atingida com LPS $1 \mu \mathrm{g} / \mathrm{ml}$. Portanto, esta concentração foi usada em todos os experimentos subsequentes.

Após verificarmos o efeito do LPS em nossas culturas passamos para o objetivo principal deste trabalho que foi avaliar o efeito da melatonina na interação neutrófilo-endotélio induzido por LPS. Nossos dados mostram o tratamento das células endoteliais por duas horas com melatonina $\left(10^{-9}\right.$ e $\left.10^{-4} \mathrm{M}\right)$ foi capaz de inibir tanto a adesão de neutrófilos quanto a expressão de moléculas de adesão (PECAM-1 e ICAM-1) com ambas as concentrações. Após isso, utilizamos um bloqueador não seletivo para receptores de melatonina, luzindol $\left(10^{-5} \mathrm{M}\right)$, para verificarmos se seu efeito inibitório era mediado por seus receptores de membrana. Os dados mostram que luzindol não foi capaz de reverter o efeito inibitório da melatonina tanto no aumento da adesão de neutrófilos quanto na expressão de moléculas de adesão.

Melatonina em concentrações próximas às utilizadas neste trabalho $\left(10^{-4} \mathrm{M}\right)$ também é capaz de inibir a expressão de iNOS e a produção de NO induzidas por LPS em células endoteliais (Tamura et al., 2009) e em macrófagos murinos (Gilad et al., 1998). Além disso, foram observados efeitos da melatonina sobre a produção cosntitutiva de óxido nítrico nas células endoteliais independentes da ativação de receptores nessa mesma concentração (Tamura et al., 2006; Silva et al., 2007). Estes efeitos da melatonina são mediados pela inibição da via de transcrição NFKB (Gilad et al., 1998, Tamura et al., 2009). Os dados obtidos com luzindol sugerem que os efeitos aqui analisados não são mediados pelos receptores de melatonina clássicos (MT1, MT2 ou MT3). Segundo Dubocovich e colaboradores (1998), a concentração de luzindol aqui utilizada $\left(10^{-5} \mathrm{M}\right)$ seria suficiente para bloquear de forma inespecífica todos os subtipos de receptores. Em retina isolada de coelho foi visto que 
luzindol $\left(4 \times 10^{-7} \mathrm{M}\right)$ bloqueou os efeitos mediados por receptores de melatonina $\mathrm{MT}_{1} \mathrm{e}$ $\mathrm{MT}_{2}$ (Dubocovich et al.,1997). Em linhagens de células transfectadas, a concentração de $1 \times 10^{-7} \mathrm{M}$ de luzindol foi capaz de inibir o receptor $\mathrm{MT}_{1}$ e com $0,1 \times 10^{-7} \mathrm{M}$ inibiu o receptor $\mathrm{MT}_{2}$ (Dubocovich et al., 1997). Apesar dos receptores de melatonina do subtipo $\mathrm{MT}_{2}$ serem mais sensíveis ao luzindol que os $\mathrm{MT}_{1}$, reforçamos que a concentração aqui utilizada deveria bloquear todos os subtipos.

A expressão de moléculas de adesão induzida por LPS é mediada por ativação de TLR4 e ativação de NFKB (Gay e Gangloff, 2007, Pober e Sessa, 2007), considerando isso, um mecanismo de ação que poderia explicar o efeito da melatonina sobre as células endoteliais seria o bloqueio da translocação nuclear de NFKB (Chuang et al., 1996, Gilad et al., 1998, Tamura et al., 2009, Cecon et al., 2010).

Os dados de inibição da adesão de neutrófilos por melatonina "in vitro" feita no presente trabalho comparados com os dados obtidos por microscopia intravital (Lotufo et al., 2001) mostra uma incongruência. Enquanto os efeitos da melatonina "in vitro" não foram bloqueados por luzindol, os efeitos "in vivo" foram bloqueados por este antagonista e o perfil farmacológico de seus efeitos sugere que a inibição do rolamento de neutrófilos sobre as células endoteliais de vênulas pós capilares seria mediado por receptores $\mathrm{MT}_{2}$, e o efeito da melatonina bloqueando a adesão de neutrófilos seria mediada por receptores de melatonina $M T_{3}$ (Lotufo et al., 2001). Neste ponto, é preciso salientar que os estudos "in vivo" foram feitos usando o LTB4 (Leucotrieno B4) e o LPS. Desta forma, não podemos descartar que a melatonina poderia atuar sobre receptores de membrana também em células endoteliais isoladas, mas podemos inferir que o efeito desta indolamina sobre LPS é mediado por outro mecanismo de ação.

Avaliamos também o efeito do tratamento crônico com melatonina e observamos que ao tratarmos as células endoteliais por 20 dias com melatonina $\left(10^{-9}\right.$ M), esta perdeu seu efeito inibitório da adesão de neutrófilos e da expressão de moléculas de adesão induzidos por LPS. No entanto, ao recolocarmos melatonina, nessas mesmas células tratadas cronicamente, 2 horas antes do experimento, seu efeito voltou a ocorrer.

Já foi demonstrado in vivo que os receptores de melatonina $\mathrm{MT}_{2}$ são passíveis de dessensibilização após ativação crônica (Hazlerigg et al., 1993; Mackenzie et al., 
2002), e no nosso trabalho verificamos que mesmo após o tratamento crônico com melatonina seguida de tratamento agudo seu efeito ainda é observado, sugerindo mais uma vez que o efeito da melatonina poderia não ser via ativação de receptores. Apesar da expressão de receptores $\mathrm{MT}_{2}$ já ter sido observada na camada íntima da artéria caudal de ratos (Masana et al., 2002), nas células endoteliais obtidas do cremaster de ratos (utilizadas neste trabalho) não foram encontrados tais receptores (Silva et al., 2007). Portanto, as ações da melatonina observadas podem ocorrer tanto de maneira dependente quanto independente da ativação de seus receptores de membrana, o que irá diferir esta maneira será o modelo utilizado e a molécula estimuladora.

Podemos destacar ainda que apesar dos dados obtidos neste trabalho serem insuficientes para descartar uma participação de receptores de membrana, visto que não foi feito um estudo farmacodinâmico completo da interação ligante-receptor, a melatonina tem a capacidade de atravessar facilmente a membrana das células, devido ao alto coeficiente de partição óleo/água (Shida et al., 1994). Por conta desta característica, a melatonina possui vários alvos intracelulares, sendo capaz, por exemplo, de se ligar com alta afinidade à calmodulina podendo interferir em diversos processos fisiológicos, e de se ligar a receptores nucleares das famílias ROR (receptor órfão para ácido retinóide) e RZR (receptor Z para ácido retinóide) (para revisão, Luchetti et al., 2010),. Assim, além de seus receptores próprios, a interação com outras proteínas e enzimas, possibilita à melatonina uma diversidade muito grande de efeitos (revisto por Markus et al., 2003).

Nossos dados permitem concluir que o estímulo de células endoteliais in vitro com LPS é capaz de aumentar tanto a expressão de moléculas de adesão (PECAM-1 e ICAM-1) quanto a adesão de neutrófilos em células endoteliais. O tratamento das células endoteliais com melatonina, tanto em concentrações próximas as encontradas no pico plasmático noturno $\left(10^{-9} \mathrm{M}\right)$ quanto em altas concentrações $\left(10^{-4} \mathrm{M}\right)$ foi capaz de inibir ambas as respostas. O tratamento contínuo com melatonina $\left(10^{-9} \mathrm{M}\right)$ ao longo de 20 dias não é capaz de inibir o aumento da adesão neutrofílica induzida por LPS, e quando a melatonina é recolocada duas horas antes do experimento a inibição volta a ocorrer. 
Em resumo, o presente trabalho mostra que a melatonina atua sobre células endoteliais de forma reversível bloqueando a adesão de neutrófilos e a expressão de moléculas de adesão nas mesmas, induzidas por LPS (figura 19).

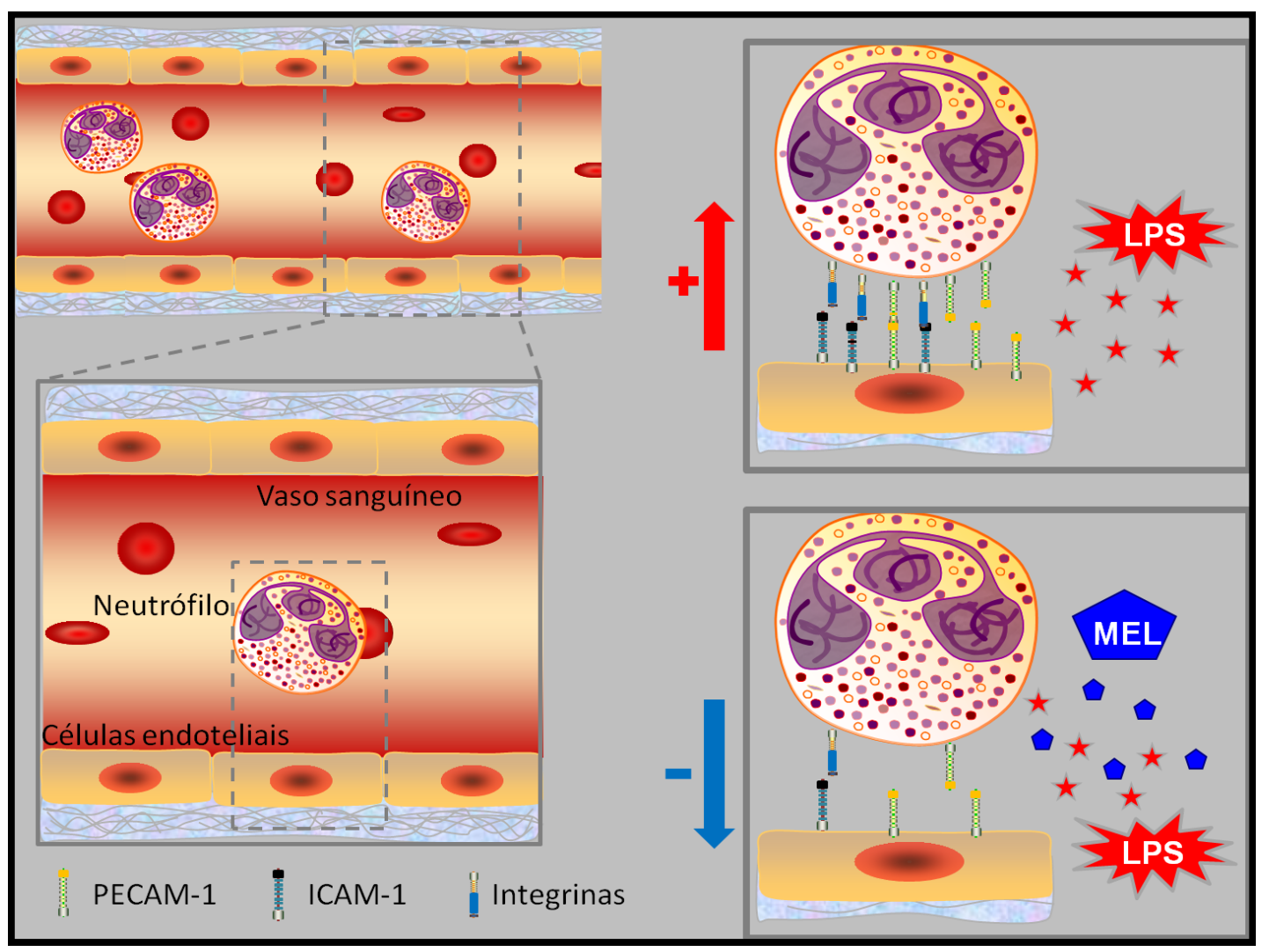

Figura 19: LPS aumenta a expressão de moléculas de adesão e melatonina inibe esse aumento. Durante um processo inflamatório agudo iniciado por exemplo, por LPS há um aumento da expressão de moléculas de adesão tanto PECAM-1 quanto ICAM-1. Quando as células endoteliais são tratadas com melatonina por 2 horas esse aumento é inibido. LPS= Lipopolissacarídeo, MEL= melatonina, PECAM-1 = moléculas de adesão de células endoteliais e plaquetas tipo 1 , ICAM-1= molécula de adesão intracelular tipo 1. 


\section{CONCLUSÕES}

- $\quad$ LPS aumenta a adesão de neutrófilos em células endoteliais in vitro

- $\quad$ Melatonina aguda inibe a adesão induzida por LPS.

- Melatonina crônica não tem efeito sobre a adesão induzida por LPS

- $\quad$ LPS aumenta a expressão de moléculas de adesão PECAM-1 e ICAM

- Melatonina bloqueia o aumento da expressão de moléculas de adesão induzido por LPS.

- Melatonina não é capaz de inibir a proliferação de células endoteliais com duas horas de incubação.

- Luzindol não bloqueou o efeito da melatonina em inibir a adesão e a expressão de moléculas de adesão. 


\section{RESUMO}

Melatonina, indolamina amplamente distribuída entre os seres vivos, é o hormônio da glândula pineal e também é produzida de forma parácrina por células imunocompetentes estimuladas. A produção de melatonina pela glândula pineal ocorre apenas no escuro e este hormônio serve para marcar a existência e a duração da noite. A monocamada de células endoteliais que reveste os vasos sanguíneos forma uma interface entre o sangue e os tecidos sendo, portanto, um sensor da presença de melatonina circulante. Essas células participam de diversos processos fisiológicos e fisiopatológicos, como na migração dos leucócitos durante a montagem de uma resposta inflamatória. Neste caso as células endoteliais são capazes de responder a padrões moleculares associados a patógenos tais como, lipopolissacarídeos (LPS) de bactérias Gram negativas. Melatonina circulante modula a interação leucócito endotélio em ratos e a expressão de moléculas de adesão em células endoteliais cultivadas. Este trabalho foi planejado com o objetivo de entender o efeito da melatonina sobre células endoteliais. Para tanto, todos os estudos foram feitos em células cultivadas ativadas ou não com LPS. Todos os ligantes foram administrados diretamente às culturas de células. Verificamos que LPS promove a expressão de moléculas de adesão (PECAM-1 e ICAM-1) e aumenta a adesão de neutrófilos. Melatonina $\left(10^{-9}\right.$ e $\left.10^{-4} \mathrm{M}, 2 \mathrm{~h}\right)$ inibe ambas as respostas. Um tratamento crônico com melatonina (20 dias) não dessensibiliza a resposta. Portanto, nossos dados mostram claramente que o efeito da melatonina se dá diretamente sobre as células endoteliais, abrindo a perspectiva de um estudo direto dos mecanismos de ação envolvidos nos efeitos gerados pela melatonina. 
Melatonin, an indoleamine widely distributed among living beings, is the hormone of the pineal gland and is also produced by stimulated immunocompetent cells. Melatonin, which is konwn as the darkness hormone, is produced at night by the pineal gland. In blood vessels, a monolayer of endothelial cells forms the interface between blood and tissue. This monolayer, which participates in several physiological and pathophysiological processes, is a sensor of circulating substances, including melatonin. Regarding the migration of leukocytes during the initiation of an inflammatory response, endothelial cells are able to respond to molecular patterns associated with pathogens such as lipopolysaccharide (LPS) of Gram-negative bacteria. Circulating melatonin modulates the interaction between leukocytes and endotelial cells and the expression of adhesion molecules. This work was planned in order to understand the effect of melatonin on endothelial cells. All studies were performed in cultured cells activated or not with LPS. All ligands were administered directly to cell cultures. We found that LPS promotes the expression of adhesion molecules (PECAM-1 and ICAM-1) and increases the adhesion of neutrophils to endotelial cells. Melatonin $\left(10^{-9}\right.$ and $10^{-4} \mathrm{M}, 2$ hours $)$ inhibits both responses. A chronic treatment with melatonin (20 days) did not desensitize the response. Therefore, our data clearly show that the effect of melatonin occurs directly on endothelial cells, opening the prospect of a direct study of the mechanisms involved in the effects produced by melatonin. 


\section{REFERÊNCIAS BIBLIOGRÁFICAS}

Albelda S.M., Smith C.W. \& Ward P.A. (1994). Adhesion molecules and inflammatory injury. The FASEB Journal 8: 504-512.

Akira S. \& Takeda K. (2004). Toll-like receptor signaling. Nat. Rev. Immunol. 7: 499-511.

Alexander J.S. \& Granger D.N. (2000) Lymphocyte trafficking mediated by vascular adhesion protein-1: implications for immune targeting and cardiovascular disease. Circulation Research 86: 1190-1192.

Andonegui, G., Goyert, S.M. \& Kubes, P. (2002). Lipopolysaccharide-Induced Leukocyte-Endothelial Cell Interactions: A Role for CD14 Versus Toll-Like Receptor 4 Within Microvessels. J. Immunol. 169: 2111-2119.

Arendt J. (1998). Melatonin and the pineal gland: influence on mammalian seasonal and circadian physiology. Journals of Reproduction and Fertility 3: 13-22.

Baeuerle P.A. \& Baltimore D. (1996). NF-kappa B: ten years after. Cell, 1: 13-20.

Baumann H. \& Gauldie J. (1994) The acute phase response. Immunology Today 15: 74-80.

Baumann H., Jahreis G.P. \& Morella K.K. (1990) Interaction of cytokine- and glucocorticoid-response elements of acute phase plasma protein genes. Journal of Biological Chemistry 36: 2275-2281.

Beaver L.M., Gvakharia B.O., Vollintine T.S., Hege D.M., Stanewsky R. \& Giebultowicz J.M. (2002). Loss of circadian clock function decreases reproductive fitness in males of Drosophila melanogaster. Proceedings of the National Academy Sciences of the United States of America 99: 2134-2139. 
Benítez-King G.,Huerto-Delgadillo L. \& Antón-Tay F. (1991). Melatonin modifies calmodulin cell levels in MDCK and N1E-115 cell lines and inhibits phosphodiesterase activity in vitro. 1-2: 289-292.

Benítez-King G. \& Antón-Tay F. (1993). Calmodulin mediates melatonin cytoskeletal effects. Experientia 8:635-641.

Benot S., Goberna R., Reiter R.J., Garcia-Maurino S., Osuna C. \& Guerrero J.M. (1999). Physiological levels of melatonin contribute to the antioxidant capacity of human serum. Journal of Pineal Research 27: 59-64.

Bird M.D., Morgan M.O., Ramirez L., Yong S., Kovacs E.J. (2010). Decreased pulmonary inflammation after ethanol exposure and burn injury in intercellularadhesion molecule-1 knockout mice. J Burn Care Res. 4: 652-660.

Bubenik G.A., Ball R.O. \& Pang S.F. (1992). The effect of food deprivation on brain and gastrointestinal tissue levels of tryptophan, serotonin, 5hydroxyindoleacetic acid, and melatonin. Journal of Pineal Research 12:7-16.

Busse R., Trogisch G. \& Bassenge E. (1985). The role of endothelium in the control of vascular tone. Basic Res Cardiol. 5: 475-490.

Carmody, R.J. \& Chen, Y.H. (2007). Nuclear Factor-kB: Activation and regulation during Toll-like receptor signaling. Cellular \& Molecular Immunology 4: 3141.

Carneiro R.C., Cipolla-Neto J. \& Markus R.P. (1991). Diurnal variation of the rat vas deferens contraction induced by stimulation of presynaptic nicotinic receptors and pineal function. J Pharmacol Exp Ther. 259: 614-619.

Carneiro R.C., Markus R.P. \& Dubocovich M.L. (1993). 2-[125I]iodomelatonin binding sites in the rat vas deferens. Biol Signals. 4:194-198.

Carrillo-Vico A., Calvo J.R., Abreu P., Lardone P.J., Garcia-Maurino S., Reiter R.J. \& Guerrero J.M. (2004). Evidence of melatonin synthesis by human 
lymphocytes and its physiological significance: possible role as intracrine, autocrine, and/or paracrine substance. The FASEB Journal 18: 537-539.

Cecon E., Fernandes P.A., Pinato L., Ferreira Z.S \& Markus R.P. (2010). Daily variation of constitutively activated nuclear factor kappa $B(N F K B)$ in rat pineal gland. Chronobiol Int. 1: 52-67.

Chen S.F., Fei X. \& Li S.H. (1995). A new simple method for isolation of microvascular endothelial cells avoiding both chemical and mechanical injuries. Microvascular Research 1: 119 - 128.

Chuang J.I., Mohan N., Meltz M.L. \& Reiter R.J. (1996). Effectof melatonin on nfkappa-B DNA- binding activity in the rat spleen. Cell Biol. Int., 20(10):687692.

Claustrat B., Brun J. \& Chazot G. (2005). The basic physiology and pathophysiology of melatonin. Elsevier 9: 11-24.

Cook-Mills, J.M. \& Deem, T.L. (2005). Active participation of endothelial cells in inflammation. Journal of Leukocyte Biology 77: 487-495.

Costa E.J.X., Lopes R.H. \& Lamy-Freund M.T. (1995). Permeability of pure lipid bilayers to melatonin. Journal of Pineal Research 19: 123-126.

Csaba G., Bodoky M. \& Törö I. (1965) Hormonal relationships of mastocytogenesis in lymphatic organs. II. effect of epiphysectomy on the genesis of mast cells. Acta Anatomica 61: 289-296.

Cui, P., Luo, Z., Zhang, H., Su, Y., Li A., Li, H., Zhang, J., Yang, Z. \& Xiu, R. (2006). Effect and mechanism of melatonin's action on the proliferation of human umbilical vein endothelial cells. J Pineal Res. 41:358-62.

da Silveira Cruz-Machado S., Carvalho-Sousa C.E., Tamura E.K., Pinato L., Cecon E., Fernandes P.A., de Avellar M.C., Ferreira Z.S. \& Markus R.P. (2010). 
TLR4 and CD14 receptors expressed in rat pineal gland trigger NFKB pathway. J Pineal Res. 2: 183-192.

de Almeida-Paula L.D., Costa-Lotufo L.V., Ferreira Z.S., Monteiro A.E., Isoldi M.C., Godinho R.O. \& Markus R.P. (2005). Melatonin modulates rat myotubeacetylcholine receptors by inhibiting calmodulin. European Journal of Pharmacology 525: 24-31.

Dong, Q.G., Bernasconi, S., Lostaglio, S., De Calmanovici, R.W., Martin-Padura, I., Breviario, F., Garlanda, C., Ramponi, S., Mantovani, A. \& Vecchi, A. (1997). A general strategy for isolation of endothelial cells from murine tissues. Characterization of two endothelial cell lines from the murine lung and subcutaneous sponge implants. Arterioscler. Thromb. Vasc. Biol. 17: 15991604.

Dubocovich M.L. (1985). Characterization of a retinal melatonin receptor. J. Pharmacol. Exper. Ther. 234: 395-399.

Dubocovich M.L. (1988). Pharmacology and function of melatonin receptors. FASEB J. 12: 2765-2773.

Dubocovich M.L., Masana M.I., Iacob S. \& Sauri D.M. (1997). Melatonin receptor antagonists that differentiate between the human Mel1a and Mel1b recombinant subtypes are used to assess the pharmacological profile of the rabbit retina ML1 presynaptic heteroreceptor. Naunyn Schmiedebergs Arch Pharmacol 3: 365375.

Dubocovich M.L., Yun K., Al-Ghoul W.M., Benloucif S., Masana M.I. (1998). Selective MT2 melatonin receptor antagonists block melatonin-mediated phase advances of circadian rhythms. FASEB J. 12: 1211-1220.

Dubocovich M.L., Cardinali D.P., Delagrange P., Krause D.N., Strosberg A.D.,Sudgen D. \& Yocca F.D. (2000) The IUPHAR Compendium of Receptor 
Characterization and Classification (2nd Edition). D. Girdlestone (Ed.), IUPHAR Media, London.

Ekmekcioglu C., Haslmayer P., Philipp C., Mehrabi M.R., Glogar H.D., Grimm M., Thalhammer T. \& Marktl W. (2001). 24h variation in the expression of the mt1 melatonin receptor subtype in coronary arteries derived from patients with coronary heart disease. Chronobiol Int. 6:973-985.

Ekmekcioglu C., Thalhammer T.,Humpeler S., Mehrabi M.R., Glogar H.D., Hölzenbein T., Markovic O., Leibetseder V.J., Strauss-Blasche G. \& Marktl W. (2003). The melatonin receptor subtype MT2 is present in the human cardiovascular system. J Pineal Res. 1:40-44.

Eppihimer M.J., Wolitzky B., Anderson D.C., Labow M.A. \& Granger D.N. (1996). Heterogeneity of expression of E- and P-selectins in vivo. 79: 560-569.

Esposito E., Iacono A., Muià C., Crisafulli C., Raso G.M., Bramanti P., Meli R. \& Cuzzocrea S. (2008). Signal transduction pathways involved in protective effects of melatonin in C6 glioma cells. Journal of Pineal Research 44: 78-87.

Fajardo L.F. (1989). The complexity of endothelial cells. A review. Am J Clin Pathol. 2: $241-250$.

Fernandes P.A., Cecon E., Markus R.P. \& Ferreira Z.S. (2006). Effect of TNF-alpha on the melatonin synthetic pathway in the rat pineal gland: basis for a 'feedback' of the immune response on circadian timing. Journal of Pineal Research 41: 344-350.

Fernandes P.A., Bothorel B., Clesse D., Monteiro A.W., Calgari C., Raison S., Simonneaux V. \& Markus R.P. (2009). Local corticosterone infusion enhances nocturnal pineal melatonin production in vivo. J Neuroendocrinol 2: 90-97.

Ferreira Z.S., Fernandes P.A., Duma D., Assreuy J., Avellar M.C. \& Markus RP. Corticosterone modulates noradrenaline-induced melatonin synthesis through inhibition of nuclear factor kappa B. J Pineal Res. 3: 182-188. 
Furchgott R.F. (1998). Nitric oxide: from basic research on isolated blood vessels to clinical relevance in diabetes. An R Acad Nac Med (Madr) 2: 317 - 331.

Gardlik R., Celec P. \& Bernadic M. (2011). Targeting angiogenesis for cancer (gene) therapy. Bratisl Lek Listy. 8: 428-434.

Gay, N.J. \& Gangloff, M. (2007). Structure and function of Toll receptors and their ligands. Annu Rev Biochem. 76: 141-165.

Gerdin M.J., Masana M.I., Rivera-Bermudez M.A., Hudson R.L., Earnest D.J., Gillette M.U. \& Dubocovich M.L. (2004). Melatonin desensitizes endogenous MT2 melatonin receptors in the rat suprachiasmatic nucleus: relevance for defining the periods of sensitivity of the mammalian circadian clock to melatonin. The FASEB Journal 18: 1646-1656.

Gilad, E., Wong, H.R., Zingarelli, B., Virág, L., O'Connor, M., Salzman, A.L. \& Szabó, C. (1998). Melatonin inhibits expression of the inducible isoform of nitric oxide synthase in murine macrophages: role of inhibition of NFkappaB activation. FASEB J. 9: 685-693.

Ghosh S. \& Hayden M.S. (2008) New regulators of NF-kappaB in inflammation. Nat Rev Immunol 8:837-848.

Ghosh S. \& Karin M. (2002). Missing pieces in the NF-kappaB puzzle. Cell 109: 8196.

Guerrero H.Y., Gauer F., Schuster C. Pevet P. \& Masson-Pevet M. (2000). Melatonin regulates the mRNA expression of the $\mathrm{mt}(1)$ melatonin receptor in the rat Pars tuberalis. Neuroendocrinology 71: 163-169.

Hastings M., O’Neill J.S. \& Maywood E.S. (2007). Circadian clocks: regulators of endocrine and metabolic rhythms. Journal of endocrinology 195: 187-198.

Hazlerigg DG, Gonzalez-Brito A, Lawson W, Hastings MH, and Morgan PJ (1993). Prolonged exposure to melatonin leads to time-dependent sensitization of 
adenyl-ate cyclase and down-regulates melatonin receptors in pars tuberalis cells fromovine pituitary. Endocrinology 132: 285-292.

Hebeda C.B., Teixeira S.A., Tamura E.K., Muscará M.N., de Mello S.B., Markus R.P. \& Farsky S.H. (2011). Nitric oxide modulates lipopolysaccharide-induced endothelial platelet endothelial cell adhesion molecule expression via interleukin-10. Clin Exp Immunol. 2:172-179.

Kadekaro A.L., Andrade L.N., Floeter-Winter L.M., Rollag M.D., Virador V., Vieira W. \& Castrucci A.M. (2004). MT-1 melatonin receptor expression increases the antiproliferative effect of melatonin on S-91 murine melanoma cells. J Pineal Res. 3: 204-211.

Kancheva R., Sulková S., Svára F., Hill M., Kanchev L. \& Zofková I. (2008). Increase of nocturnal melatonin levels in hemodialyzed patients after parathyroidectomy - a pilot study. Physiological Research/ Academia Scientiarum Bohemoslovaca.

Karasek M. \& Winczyk K. ( 2006). Melatonin in humans. Journal of Physiology and Pharmacology 57: 19-39.

Kawai, T. \& Akira, S. (2006). TLR signaling. Cell Death and Differentiation 13: $816-825$.

Kiefer T., Ram P.T., Yuan L. \& Hill S.M. (2002). Melatonin inhibits estrogen receptor transactivation and cAMP levels in breast cancer cells. Breast Cancer Res Treat. 1: 37-45.

Kim J.E., Lee S., Han K.S. \& Kim H.K. (2011). Aurintricarboxylic acid inhibits the nuclear factor- $\kappa \mathrm{B}$-dependent expression of intercellularcell adhesion molecule1 and endothelial cell selectin on activated human endothelial cells. Blood Coagul Fibrinolysis. 2: 132-139.

Klein D.C., Coon S.L., Roseboom P.H., Weller J.L., Bernard M., Gastel J.A., Zatz M., Iuvone P.M., Rodriguez I.R., Bégay V., Falcón J., Cahill G.M., Cassone 
V.M. \& Baler R. (1997). The melatonin rhythm-generating enzyme: molecular regulation of serotonin $\mathrm{N}$-acetyltransferase in the pineal gland. Recent Prog Horm Res. 52:307-357.

Lardone P.J., Carrillo-Vico A., Molinero P., Rubio A. \& Guerrero J.M. (2009). A novel interplay between membrane and nuclear melatonin receptors in human lymphocytes: significance in IL-2 production. Cell Mol Life Sci. 3: 516-525.

Lerner A.B., Takahashi y., Lee T.H. \& Mori W. (1958). Isolation of melatonin, the pineal gland factor that lightens melanocytes. J. Am. Chem. Soc. 80: 2587.

Liu F., Ng T.B. \& Fung, M.C. (2001). Pineal indoles stimulate the gene expression of immunomodulating cytokines. Journal of Neural Transmission 108: 397-405.

Lotufo, C.M.C., Lopes, C., Dubocovich, M.L., Farsky, S.H.P. \& Markus, R.P. (2001). Melatonin and Nacetylserotonin inhibit leukocyte rolling and adhesion to rat microcirculation. Eur. J. Pharmacol 430: 351-357.

Lotufo, C.M.C., Yamashita, C.E., Farsky, S.H. \& Markus, R.P. (2006). Melatonin effect on endothelial cells reduces vascular permeability increase induced by leukotriene B4. Eur. J. Pharmacol. 534: 258-63.

Lu, Y.C., Yeh, W.C. \& Ohashi, P.S. (2008). LPS/TLR4 signal transduction pathway. Cytokine 42: 145-152.

Luchetti, F., Canonico, B., Betti, M., Arcangeletti, M., Pilolli, F., Piroddi, M., Canesi, L., Papa, S. \& Galli, F. (2010). Melatonin signaling and cell protection function. FASEB J. 24: 3603-3624.

Maas M., Stapleton M., Bergom C., Mattson D.L., Newman D.K. \& Newman P.J. (2005). Endothelial cell PECAM-1 confers protection against endotoxic shock. Am J Physiol Heart Circ Physiol. 1: 159-164.

MacKenzie R.S., Melan, M.A., Passey, D.K. \& Witt-Enderby, P.A. (2002). Dual coupling of MT(1) and MT(2) melatonin receptors to cyclic AMP and 
phosphoinositide signal transduction cascades and their regulation following melatonin exposure. Biochem Pharmacol. 63: 587-95.

Maestroni G.J. (2001). The immunotherapeutic potential of melatonin. Expert Opinion on Invertigational Drugs 10: 467-476.

Markus R.P., Barbosa-Junior E.J.M. \& Ferreira Z.S. (2003). Ritmos biológicos: entendendo as horas, os dias e as estações do ano. Einstein 1: 143-147.

Markus, R.P, Ferreira, Z.S., Fernandes, P.A.C.M. \& Cecon, E. (2007). The Immunepineal axis: huttle between endocrine and paracrine melatonin. Journal of Neuroimmunomodulation 14: 126-133.

Markus, R.P., Tamura, E.K., Fernandes, P.A.C.M., Marçola, M., Monteiro, A.W.A., Cruz-Machado, S.S. (2009) Endothelial cells cultures are preconditioned by environmental lighting, melatonin and lipopolysaccharide treatment. In: XI Congress of the European Biological Rhythms Society, 2009, Strasbourg France. Anais do XI Congress of the European Biological Rhythms Society.

Markus R.P. \& Ferreira Z.S. (2011). The Immune-Pineal Axis: the role of pineal and extra-pineal melatonin in modulating inflammation. Advances in Neuroimmuno Biology.

Martín, V., Herrera, F., Carrera-Gonzalez, P., García-Santos, G., Antolín, I., Rodriguez-Blanco, J. \& Rodriguez, C. (2006) Intracellular signaling pathways involved in the cell growth inhibition of glioma cells by melatonin. Cancer Res. 66:1081-1088.

Masana M.I. \& Dubocovich M.L. (2001). Melatonin receptor signaling: finding the path through the dark. Science's STKE: Signal Trandsuctions Knowledge Environment 107: 39.

Menendez-Pelaez A., Poeggeler B., Reiter R.J., Barlow-Walden L., Pablos M.I. \& Tan D.X. (1993). Nuclear localization of melatonin in different mammalian 
tissues: immunocytochemical and radioimmunoassay evidence. Journal of Cellular Biochemistry 53: 373-382.

Moretti, R.M., Marelli, M.M., Maggi, R., Dondi, D., Motta, M. \& Limonta, P. (2000) Antiproliferative action of melatonin on human prostate cancer LNCaP cells. Oncol Rep. 7:347-351.

Mosmann, T. (1983). Rapid colorimetric assay for cellular growth and survival: Application to proliferation and cytotoxicity assays Journal of Immunological Methods 65: 55-63.

Nosjean, O., Ferro, M., Coge, F., Beauverger, P., Henlin, J.M., Lefoulon, F., Fauchere, J.L., Delagrange, P., Canet, E. \& Boutin, J.A. (2000). Identification of the melatoninbinding site MT3 as the quinone reductase 2. The Journal of Biological Chemistry 275: 31311-31317.

Nourshargh S., Krombach F. \& Dejana E. (2006). The role of JAM-A and PECAM-1 in modulating leukocyte infiltration in inflamed and ischemic tissues. Journal of Leukocyte Biology 80: 714-718.

Pandi-Perumal S.R., Srinivasan V. Maestroni, G.J., Cardinali, D.P. Poeggeler, B. \& Hardeland, R. (2006). Melatonin: Nature's most versatile biological signal?. The FEBS Journal 273: 2813-2838.

Paulis L. \& Simko F. (2007). Blood pressure modulation and cardiovascular protection by melatonin: potential mechanisms behind. Physiological Research 56: 671-684.

Petrovsky N. \& Harrison L.C. (1997). Diurnal rhythmicity of human cytokine production: a dynamic disequilibrium in $\mathrm{T}$ helper cell type 1/T helper cell type 2 balance? Journal of Immunology 158: 5163-5168.

Pober, J.S. \& Sessa, W.C. (2007). Evolving functions of endothelial cells in inflammation. Nat Rev Immunol. 7: 803-15. 
Poeggeler B., Saarela S., Reiter R.J., Tam D.X., Chen L.D., Manchester L.C. \& Barlow-Walden L. R. (1994) Melatonin--a highly potent endogenous radical scavenger and electron donor: new aspects of the oxidation chemistry of this indole accessed in vitro. Annals of the New York Academy of Sciences 738: 419-420.

Pontes, G.N., Cardoso, E.C., Carneiro-Sampaio, M.M.S. \& Markus, R.P. (2006). Injury switches melatonin production source from endocrine (pineal) to paracrine (phagocytes) - melatonin in human colostrum and colostrum phagocytes. Journal of Pineal Research 41: 136-141.

Pontes G.N., Cardoso E.C., Carneiro-Sampaio M.M. \& Markus R.P. (2007). Pineal melatonin and the innate immune response: the TNF-alpha increase after cesarean section suppresses nocturnal melatonin production. J Pineal Res. 4: 365-371.

Pozo D., Reiter R.J., Calvo J.R. \& Guerrero J.M. (1997). Inhibition of cerebellar nitric oxide synthase and cyclic GMP production by melatonin via complex formation with calmodulin. Journal of Cellular Biochemistry 65: 430-442.

Rang H.P., Dale M.M. \& Ritter, J.M. (2001). Farmacologia. 4. edi. Rio de Janeiro: Guanabara 164-188.

Reiter R.J. (1983). The pineal gland: an intermediary between the environment and the endocrine system. Psychoneuroendocrinology 1: 31-40.

Reiter R.J. (1995). Functional pleiotropy of the neurohormone melatonin: antioxidant protection and neuroendocrine regulation. Front Neuroendocrinol 16: 383-415.

Reiter R.J., Carneiro R.C., Oh C.S. (1997). Melatonin in relation to cellular antioxidative defense mechanisms. Horm Metab Res. 8: 363-372.

Reiter R.J. (2003). Melatonin: clinical relevance, Best Practice \& Research Clinical Endocrinology and Metabolism 17: 273-285. 
Reiter R.J., Tan D.X. \& Fuentes-Broto L. (2010). Melatonin: a multitasking molecule. Prog Brain Res. 181: 127-151.

Reppert S.M. (1997). Melatonin receptors: molecular biology of a new family of G protein-coupled receptors. Journal of Biological Rhythms 12: 528-531.

Robbins C.K. (1986). Patologia estrutural e funcional. 3. Edi. Rio de Janeiro: Guanabara.

Roenneberg T. \& Merrow M. (2002) "What watch?...such much!" complexity and evolution of circadian clocks. Cell and Tissue Research 309: 3-9.

Ryan U.S., White L.A., Lopez M. \& Ryan J.W. (1982). Use of microcarriers to isolate and culture pulmonary microvascular endothelium. Tissue Cell 3: 597606.

Shida C.S., Castrucci A.M. \& Lamy-Freund M.T. (1994). High melatonin solubility in aqueous medium. J Pineal Res. 4: 198-201.

Silva, C.L., Tamura, E.K., Macedo, S.M., Cecon, E., Bueno-Alves, L., Farsky, S.H., Ferreira, Z.S. \& Markus, R.P. (2007). Melatonin inhibits nitric oxide production by microvascular endothelial cells in vivo and in vitro. Br J Pharmacol. 15: 195205.

Simonneaux V. \& Ribelayga C. (2003). Generation of the melatonin endocrine message in mammals: a review of the complex regulation of melatonin synthesis by norepinephrine, peptides, and other pineal transmitters. 2: 325-395.

Skwarlo-Sonta K. (2002). Melatonin in immunity: comparative aspects. Neuro Endocrinology Letters 23: 61-66.

Skwarlo-Sonta K., Majewski P., Markowska M., Oblap R. \& Olszanska B. (2003). Bidirectional communication between the pineal gland and the immune system. Can J Physiol Pharmacol 4: 342-349. 
Soto-Vega E., Meza I., Ramírez-Rodríguez G. \& Benitez-King G. (2004). Melatonin stimulates calmodulin phosphorylation by protein kinase C. Journal of Peneal Research 37: 98-106.

Tamura, E.K., Cecon, E., Monteiro, A.W., Silva, C.L. \& Markus, R.P. (2009). Melatonin inhibits LPS-induced NO production in rat endothelial cells. J Pineal Res. 46: 268-274.

Tamura, E.K., Fernandes, P.A., Marçola, M., da Silveira Cruz-Machado, S. \& Markus, R.P. (2010) Long-lasting priming of endothelial cells by plasma melatonin levels. PLoS One. 12:e13958.

Tamura, E.K., Silva, C.L. \& Markus, R.P. (2006). Melatonin inhibits endothelial nitric oxide production in vitro. J Pineal Res. 41: 267-274.

Tan D.X., Manchester L.C., Reiter R.J., Qi W.B., Zhang M., Weintraub S.T., Cabrera J., Sainz R.M. \& Mayo J.C. (1999). Identification of highly elevated levels of melatonin in bone marrow: its origin and significance. Biochimica et Biophysica Acta 1472: 206-214.

Tan D.X., Hardeland R., Manchester L.C., Poeggeler B., Lopez-Burillo S., Mayo J.C., Sainz R.M. \& Reiter R.J. (2003). Mechanistic and comparative studies of melatonin and classic antioxidants in terms of their interactions with the ABTS cation radical. J Pineal Res. 34: 249-259.

Vanecek J. (1988). Cellular mechanisms of melatonin action. Physiol Rev. 3: 687721.

Voltarelli J.C. (1994). Fever and inflammation. Medicina, 27: 7-48.

Yuan L., Collins A.R., Dai J., Dubocovich M.L. \& Hill S.M. (2002) MT(1) melatonin receptor overexpression enhances the growth suppressive effect of melatonin in human breast cancer cells. Mol Cell Endocrinol. 1-2:147-156. 


\section{SÚMULA CURRICULAR}

\section{Dados Pessoais}

Nome Kelly Dhayane Abrantes Lima

Nome em citações bibliográficas ABRANTES-LIMA, K. D.

Nascimento 19/07/1984 - Manhuaçu/MG - Brasil

Endereço profissional Universidade de São Paulo, Instituto de Biociências, Departamento de Fisiologia Geral. Rua do Matão, travessa 14, n 321, laboratório de Cronofarmacologia, sala 323, Butantã - Sao Paulo, CEP 05508-090, SP - Brasil.

Telefone: 1130917612

URL da home page: http://www.ib.usp.br/cronofarmaco

\section{Endereço eletrônico}

e-mail para contato : kellydhayane@yahoo.com.br

e-mail alternativo : kellydhayane@ hotmail.com

\section{Formação Acadêmica/Titulação}

2008

Mestrado em Fisiologia.

Universidade de São Paulo, USP, Sao Paulo, Brasil

Título: Modulação da Interação Neutrófilo-Endotélio In Vitro por Melatonina: ação sobre as células endoteliais, Ano de obtenção: 2010

Orientador: Regina Pekelmann Markus

Bolsista do(a): Fundação de Amparo à Pesquisa do Estado de São Paulo

Palavras-chave: Interação neutrófilo-endotélio, Melatonina, Células Endoteliais, Adesão de Neutrófilos

Áreas do conhecimento : Fisiologia Geral

Setores de atividade: Pesquisa e desenvolvimento científico

2004 - 2008 Graduação em Ciências Biológicas.

Centro de Ensino Superior de Juiz de Fora, CESJF, Juiz De Fora, Brasil

Título: Melatonina: caracterização e atuação no processo inflamatório

Orientador: João Henrique Moreira Viana

Bolsista do(a): programa de Iniciação Científica CES/JF 


\section{Formação complementar}

2011 Curso de Profissionalização em Pesquisa Clínica.

Centro Paulista de Investigação Clínica, CEPIC, Brasil

2010 - 2010 Curso de curta duração em Biology of kinase proteins.

Sociedade Brasileira de Farmacologia e Terapêutica Experimental, SBFTE, Sao Paulo, Brasil

2009 - 2009 Curso de curta duração em Farmacodinâmica molecular.

Sociedade Brasileira de Farmacologia e Terapêutica Experimental, SBFTE, Sao Paulo, Brasil

2008 - 2008 Curso de curta duração em Teoria de receptores.

Sociedade Brasileira de Farmacologia e Terapêutica Experimental, SBFTE, Sao Paulo, Brasil

2007 - 2007 Curso de curta duração em Amostras não invasivas, estudo genético de animais.

Universidade Federal de Juiz de Fora, UFJF, Juiz De Fora, Brasil

2007 - 2007 Curso de curta duração em Imunologia.

Centro de Ensino Superior de Juiz de Fora, CESJF, Juiz De Fora, Brasil

2006 - 2006 Extensão universitária em Animais de Laboratório.

Instituto Butantan, IBU, Sao Paulo, Brasil

2006 - 2006 Curso de curta duração em Noções básicas de fotografia.

Centro de Ensino Superior de Juiz de Fora, CESJF, Juiz De Fora, Brasil

2005-2005 Curso de curta duração em Avanços em Biotecnologia da Reprodução.

Centro de Ensino Superior de Juiz de Fora, CES/JF, Brasil

2005 - 2005 Curso de curta duração em Métodos de estudo e conservação de primatas.

Universidade Federal de Juiz de Fora, UFJF, Juiz De Fora, Brasil

2004 - 2004 Curso de curta duração em Animais Peçonhentos.

Universidade Federal de Juiz de Fora, UFJF, Juiz De Fora, Brasil 


\section{Atuação profissional}

1. Rede Emancipa: movimento social de cursinhos populares - EMANCIPA

\section{Vínculo institucional}

2010 - Atual Vínculo: Professora voluntária , Enquadramento funcional: Professora de Biologia , Carga horária: 2, Regime: Parcial

Outras informações:

A Rede Emancipa é um movimento social de cursinhos populares préuniversitários que vem lutando para inserir estudantes de baixa renda nas universidades, principalmente públicas e nas faculdades particulares com bolsas de estudos. Nossa ação se faz com a construção de cursinhos populares em espaços cedidos, principalmente em escolas públicas. Os cursinhos da rede não possuem fins lucrativos e sua coordenação e organização são voluntárias.

\section{Universidade de São Paulo - USP}

\section{Vínculo institucional}

2010 - Atual Vínculo: Projeto REDEFOR bolsista, Enquadramento functional: Tutora EAD da disciplina "Ensino em Biologia" Carga horária: 20

\section{Vínculo institucional}

2008 - Atual Vínculo: Mestrado, Enquadramento funcional: Aluna de mestrado , Carga horária: 40, Regime: Dedicação Exclusiva

\section{Centro de Ensino Superior de Juiz de Fora - CESJF}

\section{Vínculo institucional}

2005 - 2006 Vínculo: Estagiária , Enquadramento funcional: Taxidermia , Carga horária: 20, Regime: Parcial

2005-2006 Vínculo: Estagiária , Enquadramento funcional: Manutenção da reserva técnica , Carga horária: 20, Regime: Parcial 


\section{Atividades}

01/2007 - 12/2008 Projetos de pesquisa, Centro de Ensino Superior de Juiz de Fora - MG - BRA

Participação em projetos:

Efeito da restrição alimentar e atividade física sobre o desenvolvimento, parâmetros reprodutivos $e$ longevidade de camundongos.

03/2006 - 05/2007 Estágio, Centro de Ensino Superior de Juiz de Fora - MG - BRA

Estágio:

Projeto Biologia na Rua

\section{Projetos}

2008 - 2011 Modulação da Interação Neutrófilo-Endotélio "In Vitro" por Melatonina - ação sobre as células endoteliais

Situação: Em Andamento Natureza: Desenvolvimento

Integrantes: Kelly Dhayane Abrantes Lima; Eduardo Koji Tamura; Regina Pekelmann Markus (Responsável)

Financiador(es): Fundação de Amparo à Pesquisa do Estado de São Paulo-FAPESP

2005-2007 Efeito da restrição alimentar e atividade física sobre o desenvolvimento, parâmetros reprodutivos e longevidade de camundongos.

Situação: Concluído Natureza: Pesquisa

Integrantes: Kelly Dhayane Abrantes Lima; Maria Nathália de Carvalho Magalhães Moraes; Sônia Aparecida Cordebelle de Almeida; João Henrique Moreira Viana (Responsável).

\section{Idiomas}

Inglês $\quad$ Escreve Razoavelmente, Lê Bem, Fala Pouco

Espanhol Compreende Bem, Fala Pouco, Escreve Razoavelmente, Lê Bem 


\section{Produção bibliográfica}

Trabalhos publicados em anais de eventos (resumo)

1. ABRANTES-LIMA, K. D., TAMURA, E. K., MARKUS, R. P. MELATONIN INHIBITS ADHESION OF NEUTROPHILS INDUCED BY LIPOPOLYSACCHARIDE (LPS) IN ENDOTHELIAL CELLS CULTURE In: $42^{\circ}$ Congresso Brasileiro de Farmacologia e Terapêutica Experimental, 2010, Ribeirão Preto.

Anais do $4^{\circ}$ Congresso Brasileiro de Farmacologia e Terapêutica Experimental. , 2010. v.2010. p.34 - 34

Palavras-chave: Adhesion of neutrophils, Endothelial cells, Melatonin

Áreas do conhecimento : Fisiologia Geral

Referências adicionais : Brasil/Inglês. Meio de divulgação: VáriosHome page: [http://asp.sbfte.org.br/pub/media/Session_04_Inflammation.pdf]

2. BATISTA, R. I. T. P., WOHLRES-VIANA, S., MORAES, M. N. C. M., ABRANTES-LIMA, K. D., CAMARGO, L. S. A., VIANA, J. H. M.

Respostas superovulatória em camungondos F1 produzidos a partir de diferentes estratégias de cruzamento entre linhagens endogâmicas In: XXI Reuniao Anual da SBTE, 2007, Mata de São João.

Acta Scientiae Veterinariae. , 2007. v.35. p.1299 - 1299

Referências adicionais : Brasil/Português. Meio de divulgação: Impresso

3. ABRANTES-LIMA, K. D., MORAES, M. N. C. M., MARTINS-NETO, R. G.

The diversity of the Santana Formation paleontomofauna (Lower Cretaceous, Northeaft Brazil) In: VIII Congresso de Ecologia do Brasil, 2007, Caxambu.

Anais do VIII Congresso de Ecologia do Brasil. , 2007.

Referências adicionais : Brasil/Português. Meio de divulgação: Meio digital

Trabalhos publicados em anais de eventos (resumo expandido)

1. MORAES, M. N. C. M., ABRANTES-LIMA, K. D., ALMEIDA, S. A. C., BATISTA, R. I. T. P., CAMPOS JUNIOR, P. H., MIRANDA, F. M., VIANA, J. H. M.

Efeito da restrição alimentar e espaçamento sobre o desenvolvimento somático de camundongos (resultados preliminares) In: XXX Semana de Biologia, XIII Mostra de Produção Científica, V Feira Municiapal de Ciências e II Mostra de Paleobiodiversidade, 2007, Juiz de Fora.

Resumos: XXX Semana de Biologia, XIII Mostra de Produção Científica, V Feira Municiapal de Ciências e II Mostra de Paleobiodiversidade. , 2007.

Referências adicionais : Brasil/Português. Meio de divulgação: Meio digitalHome page: [http://www.ufjf.br] 


\section{Apresentação de Trabalho}

1. MORAES, M. N. C. M., ABRANTES-LIMA, K. D., VIANA, J. H. M.

Efeito da Restrição Alimentar e Atividade Física sobre o Desenvolvimento, Parâmetros Reprodutivos e Logevidade de Camundongos, 2007. (Seminário,Apresentação de Trabalho)

Referências adicionais : Brasil/Português. Meio de divulgação: Meio digital; Local: Centro de Ensino Superior de Juiz de Fora CES/JF; Cidade: Juiz de Fora MG.; Evento: IX Seminário de Iniciação Científica; Inst.promotora/financiadora: Centro de Ensino Superior de Juiz de Fora CES/JF

\section{Produção Técnica}

Trabalhos técnicos

1. ABRANTES-LIMA, K. D.

Monitoria de Biologia Celular, 2008

Demais produções técnicas

1. ABRANTES-LIMA, K. D., MARKUS, R. P.

Modulação da Interação Neutrófilo-Endotélio "In Vitro" por Melatonina - ação sobre as células endoteliais, 2010. (Relatório de pesquisa)

\section{Palavras-chave: Melatonina, Células Endoteliais, Interação neutrófilo-endotélio Áreas do conhecimento : Farmacologia Geral,Fisiologia Geral \\ Setores de atividade : Educação \\ Referências adicionais : Brasil/Português. Meio de divulgação: Impresso}

2. ABRANTES-LIMA, K. D.

site do VII Curso de Inverno: Tópicos em Fisiologia Comparativa 2010, 2010. (Outra produção técnica)

Areas do conhecimento : Fisiologia Geral, Fisiologia Comparada

Setores de atividade : Informação e comunicação

Referências adicionais : Brasil/Português. Meio de divulgação: Meio digital

URL: http://www.ib.usp.br/cursodeinverno/old/2010/index.html\#infos

\section{ABRANTES-LIMA, K. D., FREITAS, M. M. P}

Estudos de casos em cronobiologia, 2009. (Desenvolvimento de material didático ou instrucional)

Áreas do conhecimento: Fisiologia Comparada

Referências adicionais : Brasil/Português. Meio de divulgação: VáriosHome page: http://ib.usp.br/cursodeinverno/old/2009/Livro\%20CI2009\%20completo.pdf 


\section{Participação em eventos}

1. Apresentação de Poster / Painel no(a) $\mathbf{4 2}^{\circ}$ Congresso Brasileiro de Farmacologia e Terapêutica Experimental, 2010. (Congresso) MELATONIN INHIBITS ADHESION OF NEUTROPHILS INDUCED BY LIPOPOLYSACCHARIDE (LPS) IN ENDOTHELIAL CELLS CULTURE.

2. $4^{\circ}$ Congresso Brasileiro de Farmacologia e Terapêutica Experimental, 2009. (Congresso).

3. I Symposium Immune-Pineal Axis, 2009.( Simpósio).

4. 40 ${ }^{\circ}$ Congresso Brasileiro de Farmacologia e Terapêutica Experimental, 2008. (Congresso).

5. Apresentação Oral no(a) XXX Semana de Biologia, XIII Mostra de Produção Científica, V Feira municipal de Ciências e II Mostra de Paleobiodiversidade, 2007. (Simpósio)

Efeito da restrição alimentar e espaçamento sobre o desenvolvimento somático de camundongos (resultados preliminares).

6. Apresentação de Poster / Painel no(a) VIII Congresso de Ecologia do Brasil, 2007. (Congresso)

The diversity of the Santana Formation paleoentomofauna (Lower Cretaceous, northeast Brazil).

7. III Simpósio de Ciências Biológicas do Centro de Ensino Superior de Juiz de Fora, 2007. (Simpósio).

8. 39 ${ }^{\circ}$ Congresso Brasileiro de Farmacologia Terapêutica Experimental, 2007. (Congresso).

9. Tecnologia da Reprodução, 2006. (Oficina).

10. $1^{\circ}$ Congresso do CES/JF - Educação, Direito e Cidadania, 2006. (Congresso).

11. Amazônia Azul - O Mar Que Nos Pertence, 2006. (Outra).

12. XXVIII Semana de Biologia, XI Mostra de Produção Científica e III Feira Municipal de Ciências, 2005. (Simpósio).

13. II Simpósio de Ciências Biológicas do Centro de Ensino Superior de Juiz de Fora, 2005. (Simpósio).

14. I Simpósio de Ciências Biológicas do Centro de Ensino Superior de Juiz de Fora, 2004. (Simpósio). 


\section{Organização de evento}

1. ABRANTES-LIMA, K. D., MORAES, M. N. C. M., PETRILLI, C. L, QUEIROZ, C. H. S, NARCIZO, A. M, SOUSA, C. E. C, ORTS, D. J. B, RODRIGUES. F. V, MARCHELLI, L. F. B, LAPA, M. A. P. C, FREITAS, M. M. P, KAWAMOTO, T. H VII Curso de Inverno: Tópicos em Fisiologia Comparativa, 2010. (Outro, Organização de evento)

Áreas do conhecimento : Fisiologia, Fisiologia Comparada

Setores de atividade : Educação

Referências adicionais : Brasil/Português. Meio de divulgação: Vários

O curso de inverno é idealizado por pós-graduandos do Departamento de Fisiologia do Instituto de Biociências da USP e é voltado para alunos de graduação e recémgraduados que já tenham cursado disciplina de Fisiologia, originários das diversas áreas do conhecimento que tenham interesse em Ciências Fisiológicas, mais especificamente em Fisiologia Comparativa. 